\title{
ESTADO NUTRICIONAL DE ESCOLARES MATRICULADOS EM CENTROS INTEGRADOS DE EDUCAÇÃO PÚBLICA - CIEP'S
}

UARINA VIEIRA DA SILVA

Tese apresentada à Faculdade de Saúde Pública da Universidade de São Paulo, Departamento de Nutrição, para a obtenção do título de Doutor em Saúde Pública.

Orientadora: Profa. Dra. Rosa Nilda Mazzilli

São Paulo 1996 


\section{ERRATA}

1. Na página 33, na última linha da Tabela 4 , onde se lê 581 (referente a gramas de proteina), leia-se 58.

2. Nos gráficos 3, 4 e 5 (páginas 82,84 e 85 ) as legendas com os significados das cores estão erradas. A correspondência correta, seguindo a ordem em que as cores aparecem para cada caso, é a seguinte:

- cinza claro = Energia

- marrom = Proteina

- azul = Vitamina $\mathrm{A}$

- amarelo = Tiamina

- rosa = Riboflavina

- verde = Niacina

- amarelo claro = Ácido Ascórbico

- verde musgo = Cálcio

- vermelho $\quad=$ Ferro

3. Na página 87 , no último parágrafo, onde se lê caracters, leia-se caracteres.

4. No Anexo III o segundo termo da equação de regressão é $\sum_{h=1}^{4} \beta_{h} R_{h}$ 
ESTADO NUTRICIONAL DE ESCOLARES MATRICULADOS EM

CENTROS INTEGRADOS DE EDUCAÇÃO PÚBLICA - CIEP'S

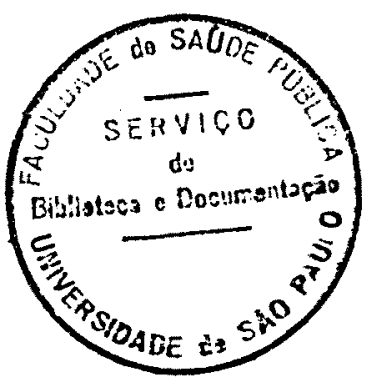

MARINA VIEIRA DA $\underbrace{\text { SILVA }}_{i N C}$

Tese apresentada à Faculdade de Saúde Pública da Universidade de São Paulo, Departamento de Nutrição, para a obtenção do título de Doutor em Saúde Pública.

ORIENTADORA:

PROF ${ }^{2}$ Dr ROSA NILDA MAZZILLI

SÃO PAULO

1996

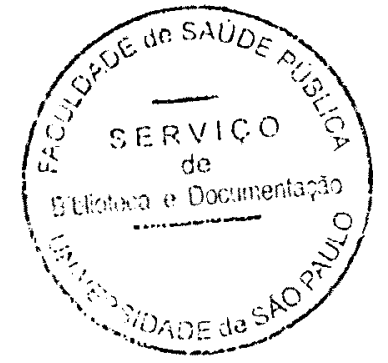


Esta Tese é dedicada aos meus pais, Elza e Geraldo (in memoriam), pela absoluta cumplicidade. 


\section{AGRADECIMENTOS}

- À Professora Doutora Rosa Nilda Mazzilli pela confiança, amizade e estímulo, e em especial, pela paciência demonstrada ao longo do meu processo de aprendizado.

- Às Professoras Doutoras Sophia Combluth Szarfarc, Maria das Graças Carvalho Ferriani, Elisabete Salay, Ignez Salas Martins e Maria Helena D'Aquino Benício pelas criticas que contribuíram para o aperfeiçoamento do trabalho.

- À Bibliotecária Angela Maria Belloni Cuenca pela revisão bibliográfica.

- Aos funcionários da Seção de Pós-Graduação e do Serviço de Aprimoramento, particularmente à Maria Aparecida Mendes.

- Ao Conselho Nacional de Desenvolvimento Científico e Tecnológico (CNPq), pela concessão da bolsa de estudos durante os anos de 1993 e 1994.

- Aos responsáveis pelo Departamento de Educação da Prefeitura Municipal de Americana e aos funcionários das unidades, particularmente ao Prof Marcos Thadeu Giongo, pela atenção e cooperação durante as atividades em campo.

- Expresso especial agradecimento a Rodolfo Hoffmann, já que muito da realização deste trabalho se deve à sua disposição em compartilhar a sua vasta experiência $\mathrm{e}$ profundos conhecimentos de estatística. 


\section{ÍNDICE}

LISTA DE TABELAS
LISTA DE GRÁFICOS
RESUMO
SUMMARY

Página

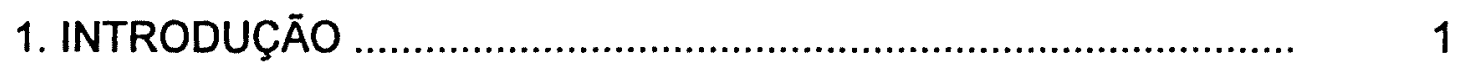

1.1. ASPECTOS HISTÓRICOS DA ALIMENTAÇÃO ESCOLAR NO BRASIL ................................................................. 4

1.2. ESTADO NUTRICIONAL DE ESCOLARES ........................... 12

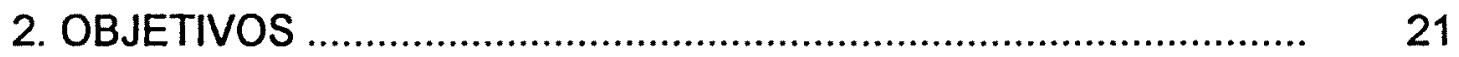

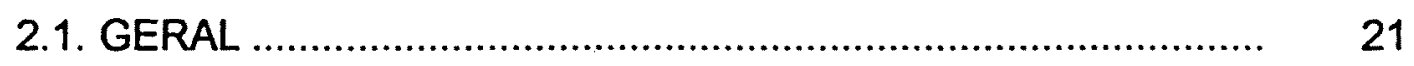

2.2. ESPECÍFICOS …......................................................... 21

3. METODOLOGIA ..................................................................... 22

3.1. LOCAL DA PESQUISA ….................................................. 22

3.2. PROCEDIMENTO AMOSTRAL …......................................... 24

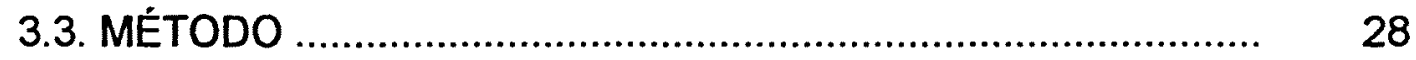

3.3.1. Estado Nutricional ..................................................... 28

3.3.2. Consumo Alimentar ................................................... 29

3.3.3. Adequação do Consumo Alimentar ................................ 31

3.3.4. Características Sócio-econômicas ................................... 33

4. RESULTADOS E DISCUSSÃO ….................................................

4.1. ESTADO NUTRICIONAL ...................................................... 35

4.2. CARACTERISTICAS DA DIETA …...................................... 53

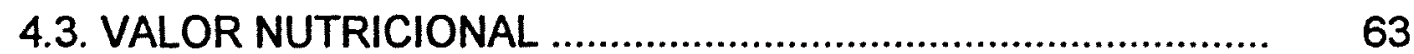

4.4. QUALIDADE NUTRICIONAL DA DIETA ............................. 81

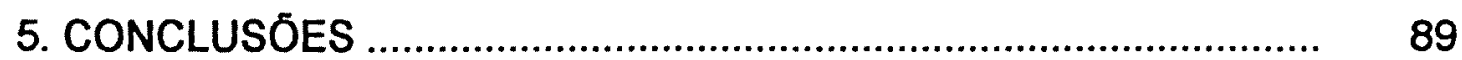

6. REFERĖNCIAS BIBLIOGRÁFICAS ................................................. 91

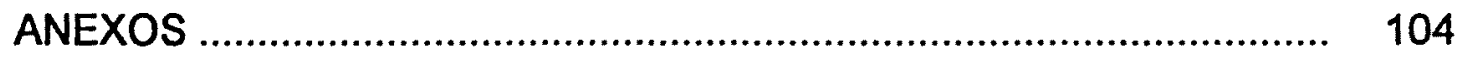




\section{LISTA DE TABELAS}

Página

TABELA 1. Distribuição dos escolares matriculados nos Centros integrados de educação pública - CIEP's, segundo idade e sexo. Americana, 1994

TABELA 2. Distribuição da amostra dos escolares matriculados nos centros integrados de educação pública CIEP's, segundo sexo e idade. Americana, 1994

TABELA 3. Valores de energia e proteinas, por quilograma de peso corporal, para as idades de 7 a 13 anos $e$ ambos os sexos

TABELA 4. Recomendaçōes de energia e nutrientes, baseadas nas recomendaçōes nutricionais para a população brasileira, adaptadas por anos de idade, segundo sexo e peso corporal

TABELA 5. Distribuição das crianças em três categorias do estado nutricional, com base no escore $Z$ de altural idade (ZAI), conforme CIEP. Americana, 1994

TABELA 6. Número e percentagem de crianças em cinco estratos de renda familiar per capita, segundo categorias do estado nutricional. Americana, 1994

TABELA 7. Prevalência de desnutrição crônica entre escolares conforme renda familiar per capita. Americana, 1994.

TABELA 8. Número e percentagem de crianças em cinco niveis de escolaridade da mãe, segundo categorias do estado nutricional. Americana, 1994

TABELA 9. Prevalência de desnutrição crônica entre escolares conforme niveis de escolaridade da mãe. Americana, 1994 
TABELA 10. Número e percentagem de crianças segundo o abastecimento de água no domicilio e categorias do estado nutricional. Americana, 1994

TABELA 11. Número e percentagem de crianças segundo o tipo de esgoto doméstico e categorias do estado nutricional. Americana, 1994

TABELA 12. Número e percentagem de crianças segundo o tipo de moradia e categorias do estado nutricional. Americana, 1994

TABELA 13. Número e percentagem de crianças segundo a freqüência à creche e/ou pré-escola e categorias do estado nutricional. Americana, 1994

TABELA 14. Prevalência de desnutrição crônica entre escolares conforme freqüência ou não à creche e pré-escola de acordo com dois estratos de renda

TABELA 15. Percentagem da presença de determinados alimentos nas refeições do dia

TABELA 16. Consumo médio diário de energia e nutrientes dos escolares, segundo faixa-etária. Americana, 1994

TABELA 17. Distribuição dos escolares de acordo com a adequação do consumo médio diário de calorias e nutrientes e CIEP's estudados. Americana, 1994

TABELA 18. Contribuição percentual média do consumo de energia e nutrientes de escolares no âmbito dos CIEP's. Americana, 1994

TABELA 19. Contribuição percentual média do consumo de energia e nutrientes de escolares, em nivel domiciliar. Americana, 1994 


\section{LISTA DE GRÁFICOS}

Página

GRÁFICO 1. Porcentagem de proteinas, lipidios totais e carboidratos em relação ao valor energético total das dietas de escolares. Americana, 1994

GRÁFICO 2. Porcentagem de proteinas, lipídios totais e carboidratos em relação ao valor energético total das dietas de escolares, segundo faixas de idade. Americana, 1994

GRÁFICO 3. "Índice de qualidade nutricional" (IQN) das dietas dos escolares, de acordo com os CIEP's. Americana, 1994

GRÁFICO 4. "Indice de qualidade nutricional" (IQN) das refeições consumidas pelos escolares no âmbito do CIEP's, segundo faixas de idade. Americana, 1994

GRÁFICO 5. "Índice de qualidade nutricional" (IQN) das refeições consumidas pelos escolares, em nível domiciliar, segundo faixas de idade. Americana, 1994 


\section{RESUMO}

Analisa-se 0 estado nutricional, bem como alguns de seus condicionantes, de 257 escolares, com 7 a 13 anos de idade, matriculados nos Centros Integrados de Educação Pública - CIEP's em Americana, estado de São Paulo. Para o diagnóstico do estado nutricional considera-se a altura do escolar, adotando classificação com base nas unidades de desvio-padrão (escore $Z$ de altura para idade). Avalia-se o consumo alimentar de 244 crianças da amostra utilizando-se o registro dos alimentos ingeridos pela criança, durante três dias não consecutivos da semana. Analisa-se a adequação de energia e nutrientes de acordo com o padrão nutricional definido para a população brasileira. Observa-se proporção de $15,6 \%$ de crianças desnutridas crônicas (ZAI < -2). Ressalta-se que através de análises estatísticas detectou-se entre outras, a influência estatisticamente significativa das variáveis rendimento familiar per capita e freqüência à creche durante a idade pré-escolar, sobre o escore $Z$ de altura para idade da criança. Isso mostra a importância de condições de vida que precedem 0 ingresso da criança no CIEP e que certamente afetaram o seu crescimento em períodos em que a criança é biologicamente mais vulnerável. Observa-se que o consumo alimentar revela-se deficiente em energia para $28,3 \%$ dos escolares, evidenciando problema relativo à quantidade dos alimentos ingeridos. No tocante à qualidade, verificam-se percentuais de proteinas e lipídios, acima dos niveis recomendados. Inversamente, no que tange os carboidratos, os percentuais médios revelam-se abaixo da recomendação. Ressalta-se que $68,9 \%$ dos escolares apresentaram alimentação com conteúdo protéico acima do preconizado. Análise das correlações simples entre a adequação do consumo de energia e nutrientes com variáveis sócio-econômicas revela que os nutrientes cuja adequação se mostra estatisticamente associada com renda familiar per capita são: energia, proteína, ferro, riboflavina, niacina e ácido ascórbico. 


\section{SUMMARY}

The nutritional status as well as certain conditioning factors of 257 students from 7 to 13 years of age registered at the Integrated Public Education Centers - CIEP's in Americana, state of São Paulo, are analyzed. Height of students is used to determine the nutritional status, with the classification based on standard deviation units (for $Z$ escore HAZ). Food intake of 244 children is evaluated through the record of food ingested in three non-consecutive days. Energy and nutrient adequacy are analyzed according to the nutritional standard established for the Brazilian population. A $15.6 \%$ ratio of children chronically going through malnutrition $(\mathrm{HAZ}<-2)$ is observed. Statistical analysis shows that the child's height for age $Z$ score is influenced by per captia family income and attendance to day-care centers during preschool age, among other variables. That shows the importance of life conditions prior to the child's entry to CIEP and which have certainly affected its growth throughout periods when a child is biologically most vulnerable. Food intake is found energydeficient for $28.3 \%$ students, thus stressing the problem concerning the amount of ingested food. As to quality, protein and lipid ratios above recommended levels are observed. Inversely, average carbohydrate ratios are under the recommendations. One should stress that the protein content in the nourishment of $68.9 \%$ students was above the recommended allowances. Simple correlation analysis between energy and nutrient consumption with social-economical variables reveals that the adequacy of nutrients statistically associated with per capita family income are energy, protein, iron, riboflavin, niacin and ascorbic acid. 


\section{INTRODUÇÃo}

No Brasil, o sistema escolar público tem reafirmado seu propósito de atender a todas às crianças em idade escolar. Contudo, pesquisas relativas aos aspectos quantitativos e qualitativos da educação no País revelam significativo déficit, sugerindo que a nobre missão de "ensinar tudo a todos" continua urgente e preocupante (FUNDAÇÃO IBGE, 1989; PIPITONE, 1991).

De acordo com a FUNDAÇĀO INSTITUTO BRASILEIRO DE GEOGRAFIA E ESTATÍSTICA - FIBGE (1989), no final do século XX, o Brasil dá evidentes sinais da incapacidade de conter a falência do sistema educacional. Além dos índices de repetência, evasão e outros índices do rendimento escolar que apontam para um ciclo vicioso, 0 analfabetismo atinge $20 \%$ da população e $26 \%$ das crianças não têm acesso à escola.

Desse modo, o propósito de cumprir o artigo constitucional que garante a educação como direito de cada um e dever do Estado, somado ao caótico quadro da educação no Pais, tem proporcionado o aparecimento de inúmeras e diferentes experiências educacionais que surgem com a promessa de solução à crise imposta ao sistema educacional vigente.

A escola pública de tempo integral é um exemplo destas propostas pedagógicas, representando uma alternativa para o problema do ensino, isto é, coloca-se como instrumento da universalização da educação básica para amplas camadas da população.

O referido modelo pedagógico visa ampliar 0 período de permanência da criança na escola, como proposta de formação integral que 
inclua, além do ensino formal, atividades culturais, recreativas, esportivas, préprofissionalizantes e o reforço escolar.

Considerando-se o contexto educacional brasileiro, há idéias contrárias e favoráveis com relação a esse modelo de escola, envolvendo diferentes justificativas para uma ou outra postura.

A argumentação contrária é desenvolvida em torno do caráter extremamente assistencialista dessas escolas. De acordo com este raciocínio, recomenda-se que se dê primeiro ensino de boa qualidade em tempo parcial, para posteriormente ampliar o tempo de escolaridade (COSTA, 1991).

Os defensores da proposta apresentam a escola de tempo integral como a solução necessária para proporcionar às crianças das camadas populares maior período diário de aprendizagem e convívio escolar (COSTA, 1991).

Deve-se considerar que as escolas de tempo integral não são novidades no cenário brasileiro.

A experiência pioneira com escolas de tempo integral, destinadas a atender crianças oriundas das classes populares, foi conduzida, em Salvador, por Anísio Teixeira, em fins de 1950 (COSTA, 1991).

Em Brasilia, em 1961, Anisio Teixeira foi responsável por projeto educacional semelhante, possibilitando, assim, a oferta de escolas de tempo integral com atividades intelectuais e manuais.

Também em 1961, no Rio de Janeiro, no governo de Carlos Lacerda, foi desenvolvido projeto de escola de tempo integral, inicialmente, em cinco escolas localizadas em favelas.

Mais recentemente, a proposta pedagógica ressurge no cenário da educação brasileira, através da experiência dos Centros Integrados de Educação Pública - CIEP's - no estado do Rio de Janeiro. Os CIEP's surgiram em 1985 no governo de Leonel Brizola sob coordenação, na época, do secretário estadual da educação, o antropólogo Darcy Ribeiro. 
O CIEP representa um projeto ousado, possuindo objetivos bem mais abrangentes do que os das escolas convencionais de $1^{\circ} \mathrm{grau}$, quais sejam: "consolidar um ensino público moderno, bem aparelhado e democrático, proporcionar aos estudantes atendimento médico, odontológico, quatro refeiçōes e banhos todos os dias, contribuindo, assim, para a assistência ao educando, na perspectiva da melhoria das condições para o desempenho escolar" (RIBEIRO, 1986).

Desse modo, o CIEP assumiu a característica de "Escola - Casa" que, segundo PARO e col (1988), pretende se responsabilizar por alguns fatores pelos quais os alunos não permanecem nas escolas ou não obtêm rendimento adequado. Os fatores citados pelos autores são a desnutrição, dificuldades para a aquisição do material escolar, doenças infecciosas, problemas visuais e auditivos.

Experiência similar à do governo do Rio de Janeiro surge no estado de São Paulo, especificamente no municipio de Americana. A partir de 1990, através da administração municipal, foi iniciada a implantação de quatro CIEP's.

A proposta de tempo integral traz para o interior da escola uma série de funçōes supletivas à funçăo pedagógica institucional que podem ser exemplificadas pelas atividades de curar, proteger, alimentar, entre outras.

Acredita-se que não há por que ser contra às funções supletivas, relacionadas à assistência médica, alimentar, etc., desde que se constituam viabilizadoras da própria função pedagógica.

Conforme argumentação de PARO e col (1988), o que não deve acontecer é a hipertrofia das atividades supletivas em detrimento da função de socialização do saber.

Vale ressaltar que em paises desenvolvidos como Japão, Canadá, Estados Unidos e França, a tendência é para universalização da escola básica em horário integral para todos os alunos, de todos os niveis sócio-econômicos (TAYLOR, 1991). 
Após a breve apresentação das experiências educacionais brasileiras no que diz respeito à escola de tempo integral, considera-se pertinente retornar as questões relacionadas às "funções supletivas" incorporadas à Escola através desse modelo pedagógico.

Destaca-se o papel fundamental assumido pela alimentação. Não há possibilidade de permanência do aluno em jornada integral se não the for assegurado o recebimento de refeições durante a jornada de aula.

No caso dos CIEP's, são servidas diariamente três refeições (desjejum, almoço e jantar).

Visando conhecer os aspectos relativos à alimentação oferecida na escola de tempo integral e alguns condicionantes do estado nutricional das crianças matriculadas nos CIEP's, do município de Americana, estado de São Paulo, optou-se pela realização do presente estudo.

Preliminarmente, nas próximas seçōes, serão apresentadas considerações sobre a evolução dos programas de alimentação escolar e as tendências do estado nutricional das crianças em idade escolar.

\subsection{ASPECTOS HISTÓRICOS DA ALIMENTAÇÃO ESCOLAR NO BRASIL}

O Brasil, dentre os países da América Latina, tem a maior e mais diversificada experiência com programas de alimentação e nutrição que visem melhorar o estado nutricional, principalmente de crianças pertencentes às familias de baixa renda (MUSGROVE, 1990).

Alguns dados são importantes para corroborar a afirmação: "gastos com programas alimentares e nutricionais aumentaram de $0,06 \%$ do Produto interno Bruto (PIB) em 1980 para 0,21\% em 1989, com um pico de $0,25 \%$ do PIB de 1987, alcançando quase 1 bilhão de dólares"(IUNES \& MONTEIRO, 1993). 
De acordo com IUNES \& MONTEIRO (1993), nos últimos dez anos os gastos com alimentação e nutrição constituiram a área de mais rápido crescimento do setor social no Brasil.

Entre os programas, destaca-se o Programa Nacional de Alimentação Escolar (PNAE)* que vigora no País há aproximadamente quarenta anos. Durante esse periodo, o PNAE não sofreu interrupçōes e apresenta como meta $O$ atendimento de 29 milhões de crianças e um custo de $\$ 327$ milhões (PELIANO, 1992).

Considerando a tradição brasileira de fornecimento de alimentos às crianças matriculadas em escolas que ofereçam ensino gratuito, optou-se por apresentar nesta seção as experiências brasileiras na área.

A distribuição de alimentos às crianças em idade escolar teve inicio na década de 30 , através do fornecimento do desjejum aos filhos de operários. A medida foi implementada pelo Serviço de Alimentação da Previdência Social - SAPS (L'ABBATE, 1982). Na época, foi elaborada a legislação que visava instituir o "copo de leite escolar" e as "sopas escolares". No entanto, tal iniciativa não foi extendida para o País como um todo, ficando restrita aos polos industriais.

A partir da segunda metade da década de 30 e durante a década de 40, liderado por Josué de Castro, o movimento da "nutrição social" contribuiu para que o governo do Estado Novo, de caráter populista, implementasse alguns programas na área de alimentação e nutrição dirigidos às camadas populares (L'ABBATE, 1982).

Desse modo, em 1945, foi instalada a Comissão Nacional de Alimentação (CNA), subordinada ao Conselho Federal de Comércio Exterior com o objetivo de formular normas para a política nacional de alimentação e nutrição, estudar o estado nutricional e os hábitos alimentares da população.

\footnotetext{
- No Brasil, O PNAE foi instituldo, inicialmente, como Campanha Nacional de Alimentaço Escolar (CNAE).
} 
Durante as décadas de 50 e 60 , ○ Brasil recebe doações de alimentos do UNICEF (United Nations Internacional Children Emergency Fund) que são destinadas aos estados do Ceará, Paraiba, Piaui e Rio Grande do Norte. No entanto, a pressão política dos demais estados fez com que as mesmas fossem expandidas. A ajuda alimentar constituia-se em leite em pó desnatado, margarina e cápsulas de vitamina A (COIMBRA, 1982).

É difícil precisar a quantidade de alimento recebido entre $1950 \mathrm{e}$ 1970 como doação. No biênio 1968/1969, por exemplo as contribuições do "Food for Development" atingiu 187.000 toneladas (SILVA, 1994).

Em 1954, o governo brasileiro apresentou proposta ao UNICEF para financiamento do Programa de Merenda Escolar.

Alguns fatores foram fundamentais para que a proposta fosse aprovada. Destacam-se o aumento da contribuição brasileira para o Fundo e a existência de acordo com os Estados Unidos para a colocação dos grandes excedentes da produção agricola para "ajudar" os países amigos. Vale ressaltar que durante o período de 1954 a 1972 o Brasil, juntamente com a India, Coréia, Chile e Vietnã do Sul, colocava-se como o país que mais recebeu ajuda alimentar do governo americano, especialmente no período após a revolução cubana. A "ajuda" decresceu durante o governo João Goulart e ampliou-se logo após militares, em 1964, terem assumido o poder (COIMBRA, 1982).

O Programa de Alimentos para a Paz foi extinto em 1972, mas o Programa de Merenda Escolar (PME), iniciado em 1954, imediatamente assumiu a característica clássica de todo o programa distributivo: sua tendência para se eternizar e se espalhar horizontalmente. Se no início dependia dos excedentes americanos, quando estes diminuiram não podia ser interrompido, pois vários segmentos da população o haviam incorporado às suas expectativas. 
Desse modo, perante a necessidade de continuar a distribuição, em plena vigência do milagre econômico, o governo brasileiro assumiu, quase integralmente, os custos do programa de alimentação escolar.

É pertinente destacar que, dentre os programas de suplementação alimentar, o PME foi o que gozou de maior continuidade. Contudo, a cobertura ainda é deficiente nas regiōes mais pobres e beneficia crianças que vivem nos limites urbanos.

$\mathrm{Na}$ década de 70 , a implantação de novos programas e a expansão dos já existentes exigiam estrutura técnica e administrativa.

Assim, pela Lei Federal de $n^{\circ} 5829 / 72$, foi criado o Instituto Nacional de Alimentação e Nutrição (INAN), autarquia vinculada ao Ministério da Saúde, visando o estabelecimento de diretrizes para a Política Nacional de Alimentação e Nutrição, consolidadas no Programa Nacional de Alimentação e Nutrição - PRONAN (INAN, 1976). O INAN surgiu em um contexto sóciopolítico-institucional em que a política social passou a ser uma preocupação explícita do Estado, constituindo uma das metas do planejamento governamental. O PRONAN engloba, entre outros, o Programa Nacional de Alimentação Escolar (PNAE) que tem como meta proporcionar suplementação alimentar aos escolares do primeiro grau, matriculados nos estabelecimentos oficiais e entidades filantrópicas de ensino e aos pré-escolares, através da proposta de fornecimento de uma refeição de valor nutricional equivalente a $15 \%$ e até $30 \%$ das recomendaçōes nutricionais diárias, durante os dias letivos.

Dentre os objetivos do programa destacam-se o aprimoramento dos hábitos alimentares, a melhoria das condições nutricionais e da capacidade de aprendizagem e redução dos índices de absenteísmo, de repetência e evasão escolar.

Com relação aos propósitos relacionados à melhoria das condiçōes de aprendizagem, convém esclarecer que se esperava que o programa de merenda escolar desempenhasse, no espaço escolar, o papel de minimizador 
do grave problema do fracasso escolar brasileiro. De acordo com esta abordagem, a escola pública passa a ser vista como um local basicamente de prestação de serviços.

Vale salientar que alguns estudos (COLLARES, 1982; MORAES, 1982) foram publicados no início dos anos 80 confirmando a correlação existente entre $o$ fornecimento da merenda escolar e a melhoria da aprendizagem. No entanto, diversas críticas e estudos (BAETA, 1982; COLLARES \& MOYSÉS, 1992; FREITAS, 1989; PATTO, 1990; VALLA, 1992) surgiram mostrando que o histórico problema do fracasso escolar não poderia ser solucionado restringindo-se a ações exclusivamente relativas ao fornecimento de alimentos aos escolares.

Ainda de acordo com o PRONAN, deve-se ressaltar que entre outras ações, o Programa propunha a racionalização do sistema de produção e comercialização de alimentos por meio da compra direta de pequenos produtores rurais. As compras nunca foram realizadas diretamente de pequenos produtores, mas de intermediários ou de grandes produtores rurais. Juntamente com os demais programas de suplementação alimentar, o PNAE passou a utilizar alimentos formulados que eram adquiridos junto a um sub setor muito especializado da indústria de alimentos. Formou-se assim um "mercado institucional" que de mercado tinha somente o nome. Havia, na verdade, de um lado um único comprador, o Estado, e do outro lado um cartel de vendedores.

Conclui-se, portanto, que ao invés de promover mudanças estruturais no sistema de produção e comercialização, o PNAE, entre outros programas, contribuiu para a consolidação do já existente.

No Brasil, o processo de descentralização/ municipalização, ocorrido ao nivel das políticas sociais a partir da década de 80 , provocou uma série de alterações no Programa de Alimentação Escolar que merecem ser analisadas.

Em 1986, houve o reconhecimento, pelo governo federal, de que o PNAE podia ser implementado, não restrito à administração federal ou estadual 
e, assim, são firmados convênios com 85 municipios brasileiros visando a concretização da municipalização da merenda escolar (SILVA \& PIPITONE, 1994).

É importante destacar que, antecipando-se à iniciativa federal, no ano de 1983, os governos estaduais de São Paulo e Rio de Janeiro deram início, em caráter experimental, à descentralização do PME. A iniciativa foi concretizada e atualmente quase a totalidade dos municipios, dos referidos estados, operacionalizam os programas de forma descentralizada.

Enfatiza-se a importância da preocupação com o atendimento dos hábitos alimentares aos escolares beneficiados pelo PME. Assim, os planejadores do programa passaram a ter opção de oferecer aos escolares refeições balanceadas, incorporando as preferências dos mesmos.

Desse modo, a partir da descentralização, o PME avança no sentido de aperfeiçoar a palatabilidade das refeiçōes servidas e passa a atuar em função de fixar hábitos alimentares que incorporem o consumo harmonioso de alimentos formulados e alimentos "in natura".

Outra vantagem, decorrente do processo de municipalização do programa de merenda escolar, é a abertura de novos canais de contato da escola com a comunidade. Assim, planejadores do programa de merenda escolar, diretores de escolas, professores, merendeiras, pais e alunos podem superar os obstáculos existentes e iniciar ou reforçar a organização da discussão em torno da merenda escolar e da escola pública para que ambas deixem de ser vistas pela população usuária apenas como um "serviço" e que se transformem em algo a ser conquistado a partir do esforço coletivo.

Também surgem, no período, algumas experiências educacionais que exigiram alteraçōes no Programa de Alimentação Escolar. Trata-se da ampliação do periodo de permanência da criança na escola. As experiências mais conhecidas são as desenvolvidas através dos CIEP's (Estado do Rio de Janeiro e municipio de Americana, Estado de São Paulo) e pela Jornada Única, 
implantada no Ciclo Básico da Rede de Ensino Público do Estado de São Paulo*.

Em 1986 foi ampliado, em nivel nacional, o Programa de Alimentação Escolar para Irmãozinhos - PAIE - estendendo a distribuição de alimentos aos irmāos entre 4 e 6 anos de idade, dos escolares.

É interessante ressaltar que, pela Carta Constitucional de 1988, a alimentação escolar consagrou-se como direito do estudante.

No final do ano de 1992, o governo federal engaja-se, de forma mais efetiva, à descentralizaçăo do PME, repassando recursos diretamente para a maioria dos estados. Praticamente todas as capitais optaram pela nova operacionalização. Contudo, em termos orçamentários, os valores repassados, para os municípios, correspondeu a aproximadamente 113 dias de atendimento, ou seja pouco mais de $50 \%$ da meta inicial.

Mesmo estando presente no Brasil, há 40 anos, sem sofrer interrupções, o PME passou por raras avaliações visando conhecer a sua real cobertura e impacto sobre o estado nutricional dos escolares.

Mais recentemente, através da divulgação da PESQUISA NACIONAL SOBRE SAÚDE E NUTRIÇÃO - PNSN (INAN, 1990) foi possivel conhecer a situação de cobertura.

Alguns dados revelam que de aproximadamente 24 milhões de crianças matriculadas em escolas públicas do primeiro grau, em 1989, 19 milhões $(78 \%)$ frequentavam escolas que ofereciam merenda escolar. No entanto, apenas $41 \%$ dos alunos afirmaram comer todos os dias a refeição distribuída (INAN, 1990).

Ainda, de acordo com a PNSN, na faixa de renda mais baixa (os $10 \%$ mais pobres), cerca de $57 \%$ dos alunos afirmavam consumir todos os dias os alimentos oferecidos. No grupo dos $10 \%$ mais ricos, apenas $18 \%$ o fazem, 
sugerindo que uma das causas para que o Programa não tenha maior cobertura é a recusa voluntária à alimentação oferecida no âmbito da escola.

Cumpre ressaltar que existem críticas, dirigidas à distribuição de alimentos nas escolas, que enfatizam a não destinação ótima do Programa, pois alcança basicamente crianças mais velhas e, portanto, menos vulneráveis, que com grande frequência não apresentam deficiências nutricionais. Destacam, também, que não é conhecida a extensão em que a merenda substitui a alimentação de casa ou, efetivamente a suplementa (FAO, 1992; IUNES \& MONTEIRO, 1993).

Contudo, estudo desenvolvido no municipio de Campinas, Estado de São Paulo aponta para a influência da merenda escolar na decisão de se colocar o filho na escola (DALL'ACQUA, 1994). De acordo com o referido estudo, cerca de $71 \%$ das familias entrevistadas (renda familiar até 2,5 salários mínimos) declararam que a alimentação escolar era importante na decisão de "mandar seus filhos à escola". Outro aspecto importante é o que se refere à alimentação que as crianças recebem em suas casas antes de irem para escola. Do total de crianças entrevistadas cerca de $36 \%$ da faixa de renda até 2,5 salários mínimos não tomavam desjejum antes de ir para a escola.

Ainda, segundo DALL'ACQUA (1994) a merenda escolar tem um efeito positivo e significativo sobre a disponibilidade per capita de calorias e proteína, mesmo depois de considerado o efeito da renda per capita. Em uma regressão múltipla do consumo per capita de calorias contra a renda per capita e uma variável binária destinada a captar o efeito da merenda escolar, a estimativa do coeficiente desta última variável mostra que o acesso à merenda aumenta aquele consumo em 357 calorias/dia. Uma equação de regressão análoga para o consumo de proteinas mostra que o acesso à merenda elevou esse consumo em 8,5g per capita/dia.

Por outro lado, merecem ser destacadas as análises apresentadas por SALAY \& CARVALHO (1995) com relação à eficácia do programa de merenda escolar no município de Campinas. Os autores determinaram a 
eficácia do PNAE com base na adequação calórica e protéica da alimentação consumida em seis escolas amostradas. Entre as conclusões, ressaltam que os percentuais de atendimento para energia $(48,6 \pm 17,3)$ e proteína $(52,5 \pm 17,2)$ não atendem o objetivo alimentar do programa ( 300 kilocalorias e $8 \mathrm{~g}$ de proteína). Demonstram os autores que são elevados os valores de sobras limpas (média geral de $36,5 \pm 23,8 \%$ ) o que sugere ocorrência de desperdícios durante o preparo das refeições.

Deve-se ressaltar que o Programa de Alimentação Escolar desenvolvido na escola de tempo integral difere, em alguns aspectos, do tradicional PNAE. Frequentemente as verbas destinadas à alimentação da escola de tempo integral são asseguradas através do orçamento municipal, facilitando a liberação dos recursos e, portanto, contribuindo para a eficiência do atendimento.

Também observa-se diferenças quanto à contribuição nutricional. No atendimento tradicional, a proposta é fornecer de 15 a $30 \%$ das recomendações de energia e proteinas, durante um periodo de 4 horas/aula.

$\mathrm{Na}$ escola de tempo integral a jornada de aula é maior, totalizando 8 horas, o que requer atendimento nutricional que atinja percentual mais elevado das recomendações de energia e nutrientes, definidas para o grupo etário.

Findas essas consideraçōes sobre a evoluçāo do programa de alimentação escolar, na próxima seção buscar-se-á elaborar análise sobre o estado nutricional da população, com ênfase na faixa de 7 a 14 anos.

\subsection{ESTADO NUTRICIONAL DE ESCOLARES}

Cumpre ressaltar que para proceder a uma análise de variações da prevalência da desnutrição é necessário comparar os dados relativos à população sob dois pontos em um determinado periodo de tempo. As amostras devem ter o máximo de similaridade quanto à origem dos dados, características 
da população, indicadores e padrão de referência utilizados e ponto de corte (GUERI, M. \& DAZA, 1991).

Estudo, realizado em conjunto por organismos internacionais (FAO, OMS, OPS, 1993), mostra as alterações observadas na prevalência de desnutrição em 17 Países sul americanos. Em 12 deles foram realizadas comparações utilizando o indicador peso/idade.

É interessante enfatizar, que dada a diversidade dos indicadores e as diferenças dos períodos de tempo, os dados apresentados, no estudo, devem ser analisados fundamentalmente para comparações das mudanças ocorridas dentro dos próprios paises e não entre os mesmos.

Verificou-se clara tendência de redução da desnutrição na maioria dos paises estudados, com exceção de Guatemala e Panamá. No caso do Brasil, observou-se prevalência da desnutriçăo de 18,4\% em 1974/1975 e 7,0\% no ano de 1989 (MONTEIRO e col, 1992).

A melhoria do estado nutricional deve ser interpretada como decorrente do aumento observado, na maioria dos Paises, da disponibilidade de energia, dos esforços empreendidos durante os anos 80 para promover o aleitamento materno, das campanhas de imunização e do controle de doenças diarréicas e respiratórias (BANCO MUNDIAL, 1992; FAO, 1993; FIBGE, 1989; OPS, 1990).

De acordo com MACIAS e col (1980) os paises em desenvolvimento têm realizado diagnósticos que possibilitam o conhecimento sobre o tipo de problemas nutricionais que afetam as suas populações. Contudo, não é frequente a disponibilidade de dados sobre a magnitude, a distribuição geográfica e a periodicidade de tais agravos, bem como análises que identifiquem 0 .conjunto de fatores causais que, direta ou indiretamente, condicionam o estado nutricional.

Durante os últimos anos diversos países vêm realizando censos de altura em crianças (geralmente de 6 a 9 anos de idade), pertencentes à primeira série do primeiro grau da rede de ensino. 
Os censos de altura apresentam a vantagem de contar, na maioria dos paises, com cobertura do sistema escolar superior à observada para os serviços de saúde (FAO, 1993).

Deve-se enfatizar que alguns aspectos podem introduzir erros, limitando, assim, a utilidade dos dados obtidos através dos censos. Pode-se citar, entre outros, alguns exemplos, como a falta de representatividade na situação de escolas com respeito ao ambiente geográfico, à ausência dos grupos de crianças não matriculadas em escolas (com grande possibilidade de apresentarem prevalência de déficit de altura maior do que o de crianças que frequentam escolas), da representatividade estatística de escolas com número de alunos muito pequeno e a repetição da primeira tomada da medida de altura.

FREIRE \& BACALLAO (1992) sugerem que, nos paises com altas taxas de escolaridade, o censo de altura/idade deve ser realizado em crianças entre 6 e 7 anos e 11 meses, independente da série escolar em que se encontrem, e indicam que mesmo carecendo, em alguns casos, de representatividade, os censos são úteis para obter, através de baixo custo, informaçōes relativas ao nivel sócio-econômico da localidade e poderá subsidiar elaboração de programas sociais.

Justifica-se a utilização da altura da criança em idade escolar como indicador do estado nutricional e das condições de saúde da população em geral, devido à constatação de que a relação alturalidade, nesta faixa etária, resume satisfatoriamente os episódios sociais, econômicos e biológicos ocorridos com a criança desde sua concepção (MASON, 1984; VALVERDE, 1985).

No Brasil, alguns estados possuem experiências com a rẹalização de censos antropométricos, envolvendo crianças pertencentes à rede oficial de ensino.

No Estado do Ceará, foram analisadas informaçōes referentes a 63.910 escolares $(45,33 \%$ da população matriculada, com idade entre 6 a 9 
anos). Os autores (GUERRA e col, 1993) observaram que o retardo severo em altura foi de $2,68 \%$ que, acrescido ao retardo moderado, totalizou $17,23 \%$ de prevalência do retardo estatural entre as crianças em nivel estadual. Tal constatação reflete uma prevalência do retardo em altura/idade, no Estado, de 7,59 vezes acima da proporção verificada na população de referência $(2,27 \%)$.

No censo realizado entre escolares, da $7^{\mathrm{a}}$ Região Educacional do estado da Paraiba, os autores (RIVERA e col, 1994) observaram que há maior prevalência de desnutrição crônica entre as crianças de 9 anos de idade $(21,85 \%)$. Entre os escolares com 7 e 8 anos, os percentuais são 19,94 e 19,39 , respectivamente. Os autores concluíram também que, embora a desnutrição crônica atinja todos os grupamentos etários de maneira semelhante, a prevalência é superior entre as crianças matriculadas em escolas da zona rural do Estado.

De acordo com TURNER (1978) invariavelmente as crianças do setor rural são freqüentemente menores e com ritmo de crescimento mais lento do que as crianças que vivem em áreas urbanas em decorrência de fatores como maior precariedade dos serviços de saúde e educação e da irregularidade do consumo de alimentos. $O$ autor destaca, também, que as crianças das áreas rurais despendem mais energia em atividades físicas e freqüentemente 0 atendimento das necessidades de energia é menor do que o apresentado por crianças do setor urbano.

Antecipando-se às discussões sobre a evolução do estado nutricional da população infantil brasileira nos últimos anos, tece-se considerações sobre alguns indicadores que expressam a situação social do País.

Tais considerações parecem ser pertinentes, pois a interação entre situação econômica e políticas públicas na determinação do estado nutricional da população tem sido bastante discutida.

No Brasil, mais recentemente, foi observado que os diferentes períodos de crise enfrentados pela economia nacional e o aumento dos níveis 
de desigualdade, embora resultassem em elevação dos niveis de pobreza absoluta, não impediram a evolução positiva de uma série de indicadores sociais.

Faz-se necessário mencionar que a série, para o País como um todo, mostra taxas de mortalidade infantil com declínios intensos e sistemáticos para o período de 1977 a 1982. Durante os anos de 1983 e 1984 observa-se interrupção e posteriormente reduções menores, mas contínuas, até 1989. (FIBGE, 1989; Fundação SEADE, 1989).

Verifica-se, também, aumento significativo de proporção de crianças vacinadas contra doenças infecciosas. No caso de crianças que receberam imunização contra o sarampo, a proporção aumenta de três vezes, de $16 \%$ em 1975 para $59 \%$ em 1988.

No periodo, observou-se significativa expansão da rede de saneamento básico. A população urbana que recebe água tratada aumentou de $51 \%$ em 1970 para $84,5 \%$ em 1984 (CEPAL, 1990).

Quando se analisam os dados relativos à educação, verifica-se uma tendência geral positiva na alfabetização e na educação básica, consistentemente maiores para mulheres em idade reprodutiva (MONTEIRO, 1993).

Contudo, otimismo descabido deve ser evitado, atentando-se para o fato de que os ganhos obtidos em termos dos mencionados indicadores não colocam o Brasil em posição confortável na área social, nem mesmo quando se adota como referência os demais Países da América Latina.

Neste contexto de expressivo avanço dos indicadores sociais, constatou-se também melhoras razoáveis no estado nutricional infantil, em todas as regiōes do País e nas diferentes camadas sócio-econômicas da população.

É necessário enfatizar a importância que os dois primeiros anos de vida da criança exercem sobre sua altura na idade escolar, por ser um periodo particularmente vulnerável para seu crescimento e desenvolvimento. Assim, de 
acordo com alguns autores (MONDINI, 1990; MONTEIRO, 1989) mudanças a partir de um determinado momento levariam certo tempo até se expressarem inteiramente na altura dos escolares.

Quando se comparam os dados referentes à altura média de meninos e meninas de 6 e 7 anos (crianças que nasceram durante o auge da crise econômica), observados pela PNSN (INAN, 1990), realizada entre julho e setembro de 1989, com os dados obtidos pelo ESTUDO NACIONAL DE DESPESAS FAMILIARES - ENDEF (FIBGE, 1978) constata-se crescimento significativo da altura das crianças brasileiras nas áreas rural e urbana.

Os dados da PNSN evidenciam que aos 7 anos de idade a diferença de altura entre a criança americana e brasileira é de $4,0 \mathrm{~cm}$, e que entre os 20 e 25 anos, mais de $20 \%$ dos brasileiros possuem medidas de altura que podem ser caracterizadas como nanismo(FAO, 1993).

De acordo com IUNES \& MONTEIRO (1993) o déficit médio* de altura, no Brasil, foi diminuído pela metade entre as duas pesquisas; de aproximadamente 7,0cm em 1975 para cerca de 3,5 em 1989.

Com respeito a este aspecto, MORCILLO (1987) comparou indices antropométricos de 2055 crianças de escolas de $1^{\circ}$ e $2^{\circ}$ graus da cidade de Paulínia, estado de São Paulo, com idade entre 6 e 12,5 anos, no periodo de 1984-1985 com resultados obtidos em estudo realizado no período de 19791980. Os resultados apontam para valores das médias de altura nas primeiras faixas-etárias, significativamente superiores no período de 1984-1985. Concluiu, também, que o processo de crescimento se manteve equilibrado entre os dois estudos, considerando-se as pequenas diferenças observadas entre as médias da adequação peso-altura. As alterações da curva de estatura permitiram concluir que ocorreram modificaçōes nas condiçōes de saúde da

- Diferença na média das crianças brasileiras em relaçao ao padrao de referéncia (NCHS, 1976) 
população dessa faixa-etária que atuaram, de forma favorável, sobre o processo de crescimento das crianças.

Quando se considera dados obtidos pela PNSN, verifica-se que, na população brasileira menor de 10 anos de idade, a natureza da desnutrição é de caráter mais crônico que agudo, estando as crianças com desnutrição crônica concentradas nas famílias cuja renda mensal é inferior a 2 salários mínimos. Ressalta-se que a distribuição dos índices de estatura para idade foi praticamente idêntica à da populaçäo de referência nas famílias com renda mensal superior a 5 salários minimos.

Estudo de AMIGO e col (1995) buscando investigar o estado nutricional de escolares de 6 a 8 anos de idade pertencentes a estratos de baixo nível sócio-econômico de Santiago (Chile) e da cidade de São Paulo (Brasil) revelou prevalência de retardo de crescimento de 23,1\% em São Paulo enquanto em Santiago a proporção atinge 39,9. O menor déficit de altura observado entre escolares de São Paulo é atribuido à existência de melhores condições de vida posteriores ao nascimento para essa população, uma vez que o déficit de altura é em parte atribuido a uma exposição a condiçōes ambientais adversas, especialmente se ocorrem nos primeiros anos de vida. Ressaltam, também, que no periodo de 1984-1986 (período referente ao nascimento das crianças que participaram do estudo) verificou-se no Brasil, uma melhora no desempenho da economia, depois de um período recessivo ocorrido no início da década dos 80 .

Com relação às carências específicas, a prevalência de anemia entre crianças em idade escolar tem merecido atenção especial. Devido ao aumento das necessidades de ferro, imposto pela rápida expansão da massa celular vermelha e pelo acentuado crescimento dos tecidos, as crianças e adolescentes constituem grupos particularmente vulneráveis à deficiência de ferro. 
É importante ressaltar que a associação entre carência de ferro, com ou sem anemia, e alterações no rendimento escolar foi descrita por vários autores (POLLITT, 1985; SESHADRI, 1982; WEBB \& OSKI, 1973).

MOYSÉS (1979) estudou experimentalmente 251 escolares com idade entre 7 e 14 anos, observando que quando se administra ferro para esse grupo ocorre razoável melhora no desenvolvimento cognitivo. De acordo com a autora, a correção da anemia permite significativa melhora no padrão visual e no sistema de memória, a qual reflete no potencial do aprendizado escolar.

Em São Carlos, município do interior paulista, estudo relativo a 254 escolares revelou anemia em $9,6 \%$ das crianças (PEDRAZZANI, 1988). Em estudo também entre 370 escolares, realizado no interior do estado de São Paulo, a prevalència de anemia entre crianças de 6 a 14 anos de idade foi de $24,5 \%$ e $22,9 \%$, respectivamente (TONE, 1983).

CESAR (1990) estudando amostra de 380 escolares paulistanos encontrou proporção de $60,3 \%$ de anêmicos. Observou diferença entre os indivíduos segundo o sexo, sendo identificados $71 \%$ de meninos anêmicos e $61 \%$ de meninas.

UCHIMURA (1994), estudando a anemia e desnutrição entre 334 escolares ingressantes na $1^{\circ}$ série do $1^{\circ} \mathrm{grau}$ de escolas estaduais, encontrou $31,7 \%$ de crianças anêmicas e $2,7 \%$ de crianças desnutridas. Constatou, também, que a desnutrição é mais acentuada nas idades mais avançadas, 0 mesmo não ocorrendo com a anemia. A autora conclui que a anemia está associada ao não consumo habitual de feijōes e carnes consideradas fontes importantes de ferro dietético e à ausência de frutas, consideradas fontes de vitamina $\mathrm{C}$ que desempenha papel potencializador para a biodisponibilidade do ferro.

LERNER (1994) conduziu estudo visando conhecer a prevalência de anemia e a prática alimentar entre adolescentes das escolas públicas de Osasco, São Paulo. Verificou que a prevalência da anemia foi de $5,3 \%$, não havendo diferença entre os individuos segundo o sexo. Segundo a autora a 
proporção é pequena e comparável à de paises desenvolvidos. No entanto, o consumo de ferro total revelou-se inadequado para a maior parte da populaçăo, sendo que mais de $55 \%$ não atingiu sequer a metade do ferro recomendado.

É oportuno ressaltar que os resultados de estudos sobre desnutrição e anemia na população escolar, bem como as repercussões da deficiência do ferro, justificam a adoção de ações que contribuam para a prevenção dessa deficiência nutricional.

Entre as diversas estratégias de intervenção, destaca-se a adição de ferro nos alimentos industrializados e a utilização do ácido ascórbico, através da estrutura do Programa de Alimentação Escolar.

Face ao exposto nessa seção e tendo em vista os conhecimentos das lacunas existentes nas peculiaridades do programa de alimentação desenvolvido na Escola de Tempo Integral, bem como o estado nutricional de seu público-alvo, optou-se pela realização de estudo que permita conhecer o estado nutricional dos escolares, procurando associá-lo a alguns determinantes sócio-conômicos e ambientais. Visa-se também analisar o consumo alimentar das crianças, tanto no âmbito da escola quanto em nivel domiciliar. 


\section{OBJETIVOS}

\subsection{OBJETIVO GERAL}

- Avaliar o estado nutricional de escolares matriculados nos CENTROS INTEGRADOS DE EDUCAÇÃO PÚBLICA - CIEP's e analisar os seus condicionantes.

\subsection{OBJETIVOS ESPECIFICOS}

- Identificar a prevalência da desnutrição na população de estudo;

- Identificar a associação entre fatores sócio-econômicos e ambientais e o estado nutricional da população estudada.

- Conhecer o consumo alimentar diário de escolares matriculados nos CIEP's;

- Verificar a contribuição de calorias e de nutrientes das refeições servidas aos escolares no âmbito do CIEP. 


\section{METODOLOGIA}

\subsection{LOCAL DA PESQUISA}

Americana é um município localizado na Regiāo Administrativa de Campinas que possui $144,0 \mathrm{~km}^{2}$ de extensão territorial e 153.840 habitantes. A taxa de urbanizaçăo do município é de $99,88 \%$ e a densidade demográfica, 1.067,91 hab/km² (FUNDAÇÃO SEADE, 1991).

O Município é um dos maiores produtores de tecidos do Pais; $50 \%$ de todo ramo industrial, que atualmente conta com 958 empresas, é de atividade têxtil. Da outra metade das indústrias de transformação, $25 \%$ também estão ligadas ao ramo. As indústrias de tecelagem são as maiores empregadoras de mão-de-obra da cidade (FUNDAÇÃO SEADE, 1993).

Alguns indicadores sociais revelam que Americana possui taxa de natalidade de 21,28 , de mortalidade, 4,60 e taxa de mortalidade infantil de $17,47^{\circ}$ (FUNDAÇĀO SEADE, 1993).

No que diz respeito à educação, o Municipio conta com 36 escolas estaduais e 35 escolas municipais, além de 29 escolas particulares que fornecem vagas, anualmente, a 50 mil alunos. Ressalta-se que $35 \%$ do orçamento municipal é destinado à educação.

\footnotetext{
"Taxa de mortalidade intantil: obitos de menores de um ano, residentes no municipio, ocorridos durante o ano considerado, por mil nascidos vivos no mesmo ano.
} 
Analisando-se dados sobre matriculas das redes estadual, municipal e particular de ensino de $1^{\circ}$ e $2^{\circ}$ graus, observa-se evasão de 7,23 e $24,64 \%$, respectivamente.

Com relação aos dados de reprovação, verificam-se valores de 13,19\% (ensino público de $1^{\circ} \mathrm{grau}$ ) e $10,08 \%$ (ensino público de $2^{\circ}$ grau) (FUNDAÇÃO SEADE, 1993).

Deve-se destacar que o municipio de Americana foi o único, no Estado de São Paulo, a implantar as escolas de tempo integral, destinadas ao atendimento de crianças da faixa-etária de 7 a 14 anos . Atualmente estão em funcionamento 4 Centros Integrados de Educação Pública - CIEP's, localizados em bairros onde se concentram grande contingente de famílias de baixa renda*.

Os CIEP's são vinculados ao Departamento de Educação da Prefeitura Municipal, através da Divisão de Ensino Fundamental.

o programa de alimentação, operacionalizado nos CIEP's, subordina-se ao Setor de Alimentação e Nutrição que conta com os seguintes profissionais: 01 nutricionista, 02 técnicos de alimentos, 03 secretários, 05 motoristas e 12 operadores.

O referido setor é responsável, também, pelo planejamento dos serviços de alimentação desenvolvidos nas escolas municipais de educação infantil (EMEl's), programa de merenda escolar (Rede de Ensino Estadual) e creches municipais.

O Setor de Alimentação e Nutrição conta com estruturas de açougue, padaria (produção de 15.000 unidades diárias de pão tipo "francês") e usina de produção do extrato hidrossolúvel de soja (200 litros/dia).

\footnotetext{
- De acondo corn o Conso Demografico de 1991, o munićpio possui, na faixa etária de 5 a 14 anos, 15.287 meninos e 14.393 menimas, totalizando 29.680 crianças

"Segundo dados divulgados pelo IPEA, através do "Mapa da Fone", Americana possui 2.282 familias, cuja renda familiar corresponde, no máximo, ao valor de aquisiça da cesta básica de alimentos que atendam aos requerimentos recomendados pela FAO/OMS/UNU para a familia como um todo.
} 


\subsection{PROCEDIMENTO AMOSTRAL}

Para a execução da pesquisa realizou-se junto à diretoria dos 4 CIEP's levantamento preliminar, visando a obtenção de informaçōes relativas ao número de alunos matriculados em cada unidade. Levantaram-se também os dados referentes à identificação da criança (nome completo, sexo, data de nascimento e endereço).

Na TABELA 1 é apresentada a distribuiçāo dos escolares de acordo com a unidade, sexo e idade. 
TABELA 1. Distribuição dos escolares matriculados nos centros integrados de educação pública - CIEP's segundo idade e sexo. Americana, 1994.

\begin{tabular}{|c|c|c|c|c|c|c|}
\hline & & \multicolumn{4}{|c|}{ CIEP's ${ }^{* *}$} & \multirow[b]{2}{*}{ Total } \\
\hline \multicolumn{2}{|c|}{ Idade $/$ Sexo } & 1 & II & III & IV & \\
\hline \multirow[t]{3}{*}{7} & $M$ & $56 \quad(49,6)$ & $54 \quad(52,9)$ & $58 \quad(53,6)$ & $59 \quad(52,2)$ & $227 \quad(51,9)$ \\
\hline & $F$ & $57 \quad(50,4)$ & $48 \quad(47,1)$ & $51 \quad(46,4)$ & $54 \quad(47,8)$ & $210 \quad(48,1)$ \\
\hline & $T$ & $113(100,0)$ & $102(100,0)$ & $109(100,0)$ & $113(100,0)$ & $437(100,0)$ \\
\hline \multirow[t]{3}{*}{8} & $M$ & $51 \quad(49,0)$ & $50 \quad(51,5)$ & $56 \quad(56,0)$ & $59 \quad(55,1)$ & $216 \quad(52,9)$ \\
\hline & $F$ & $53(51,0)$ & $47(48,5)$ & $44(44,0)$ & $48 \quad(44,9)$ & $192(47,1)$ \\
\hline & $T$ & $104(100,0)$ & $97(100,0)$ & $100(100,0)$ & $107(100,0)$ & $408(100,0)$ \\
\hline \multirow[t]{3}{*}{9} & $M$ & $54 \quad(55,1)$ & $50 \quad(52,6)$ & $51 \quad(53,1)$ & $51 \quad(49,0)$ & $206 \quad(52,1)$ \\
\hline & $F$ & $44 \quad(44,9)$ & $45 \quad(47,4)$ & $45 \quad(46,9)$ & $53 \quad(51,8)$ & $187(47,9)$ \\
\hline & $\mathrm{T}$ & $98(100,0)$ & $95(100,0)$ & $96(100,0)$ & $104(100,0)$ & $393(100,0)$ \\
\hline \multirow[t]{3}{*}{10} & $M$ & $46 \quad(49,5)$ & $42(46,7)$ & $49 \quad(51,0)$ & $48 \quad(51,6)$ & $185 \quad(49,7)$ \\
\hline & $F$ & $47 \quad(50,5)$ & $48 \quad(53,3)$ & $47 \quad(49,0)$ & $45 \quad(48,4)$ & $187 \quad(50,3)$ \\
\hline & $T$ & $93(100,0)$ & $90(100,0)$ & $96(100,0)$ & $93(100,0)$ & $372(100,0)$ \\
\hline \multirow[t]{3}{*}{11} & $M$ & $43 \quad(46,7)$ & $45 \quad(50,5)$ & $44(51,7)$ & $43 \quad(48,9)$ & $175 \quad(49,4)$ \\
\hline & $F$ & $49 \quad(53,3)$ & $44 \quad(49,4)$ & $42 \quad(48,3)$ & $45 \quad(51,1)$ & $180 \quad(50,6)$ \\
\hline & $T$ & $92(100,0)$ & $89(100,0)$ & $86(100,0)$ & $88(100,0)$ & $355(100,0)$ \\
\hline \multirow[t]{3}{*}{12} & $\mathbf{M}$ & $39 \quad(46,4)$ & $40 \quad(47,0)$ & $41 \quad(49,4)$ & $35 \quad(45,5)$ & $155 \quad(46,8)$ \\
\hline & $F$ & $45 \quad(53,6)$ & $45 \quad(53,0)$ & $42(50,6)$ & $42(54,5)$ & $174(53,2)$ \\
\hline & $\mathrm{T}$ & $84(100,0)$ & $85(100,0)$ & $83(100,0)$ & $77(100,0)$ & $329(100,0)$ \\
\hline \multirow[t]{3}{*}{13} & $M$ & $35 \quad(47,9)$ & $39 \quad(50,6)$ & $39 \quad(55,7)$ & $30 \quad(46,1)$ & $143(50,2)$ \\
\hline & $\mathbf{F}$ & $38 \quad(52,1)$ & $38 \quad(49,4)$ & $31 \quad(44,3)$ & $35 \quad(53,9)$ & $142(49,8)$ \\
\hline & $T$ & $73(100,0)$ & $77(100,0)$ & $70(100,0)$ & $65(100,0)$ & $285(100,0)$ \\
\hline TOTAL & & 657 & 635 & 640 & 647 & 2579 \\
\hline
\end{tabular}

* Idade expressa em anos

* 1 - CIEP Prof. Octávio C. Borghi

II - CIEP Prof ${ }^{\circledR a}$ Philomena M. Bassete

III - CIEP Prof Oniva de M. Brizolla

IV-CIEP Prof. Anísio S. Teixeira 
É interessante notar que há maior número de crianças matriculadas nas primeiras séries do primeiro grau, com concentrações decrescentes nas séries subsequentes. De acordo com o Coordenador do Programa de Educação da Prefeitura Municipal há elevado número de transferências de alunos para as classes do período noturno das escolas da Rede Estadual de Ensino, quando os mesmos atingem a idade de onze anos. Os pedidos são justificados pela necessidade do aluno incorporar-se ao mercado de trabalho.

Trata-se, possivelmente, da consequência de um processo que já vem ocorrendo na Brasil há alguns anos (BRUSCHINI, 1990; FIBGE, 1994; MONTALI, 1990). Na tentativa de superar os graves problemas econômicos, as famílias de baixa renda lançam mão da superutilização de seus membros (principalmente menores) como trabalhadores.

Uma vez identificadas as 2579 crianças, fêz-se a classificação em 7 grupos de idade em cada um dos CIEP's, distinguindo-as por sexo. Assim, obteve-se: 4 ( $n^{\circ}$ de CIEP's) $\times 7$ ( $n^{\circ}$ de grupos de idade) $\times 2$ (sexos: masculino e feminino $)=56$ estratos.

Para a composição da amostra estratificada proporcional, optou-se pelo sorteio de $10 \%$ dos escolares matriculados, obtendo se assim 257 crianças. Esse procedimento garante que a distribuição das crianças conforme CIEP's, sexo e grupos etários seja idêntica à sua distribuiçāo na população considerada.

Na TABELA 2 pode-se verificar como os 257 escolares da amostra se distribuem com relação aos CIEP's, grupos de idade e sexo. 
TABELA 2. Distribuição da amostra dos escolares matriculados nos centros integrados de educação pública - CIEP's, segundo sexo e idade. Americana, 1994.

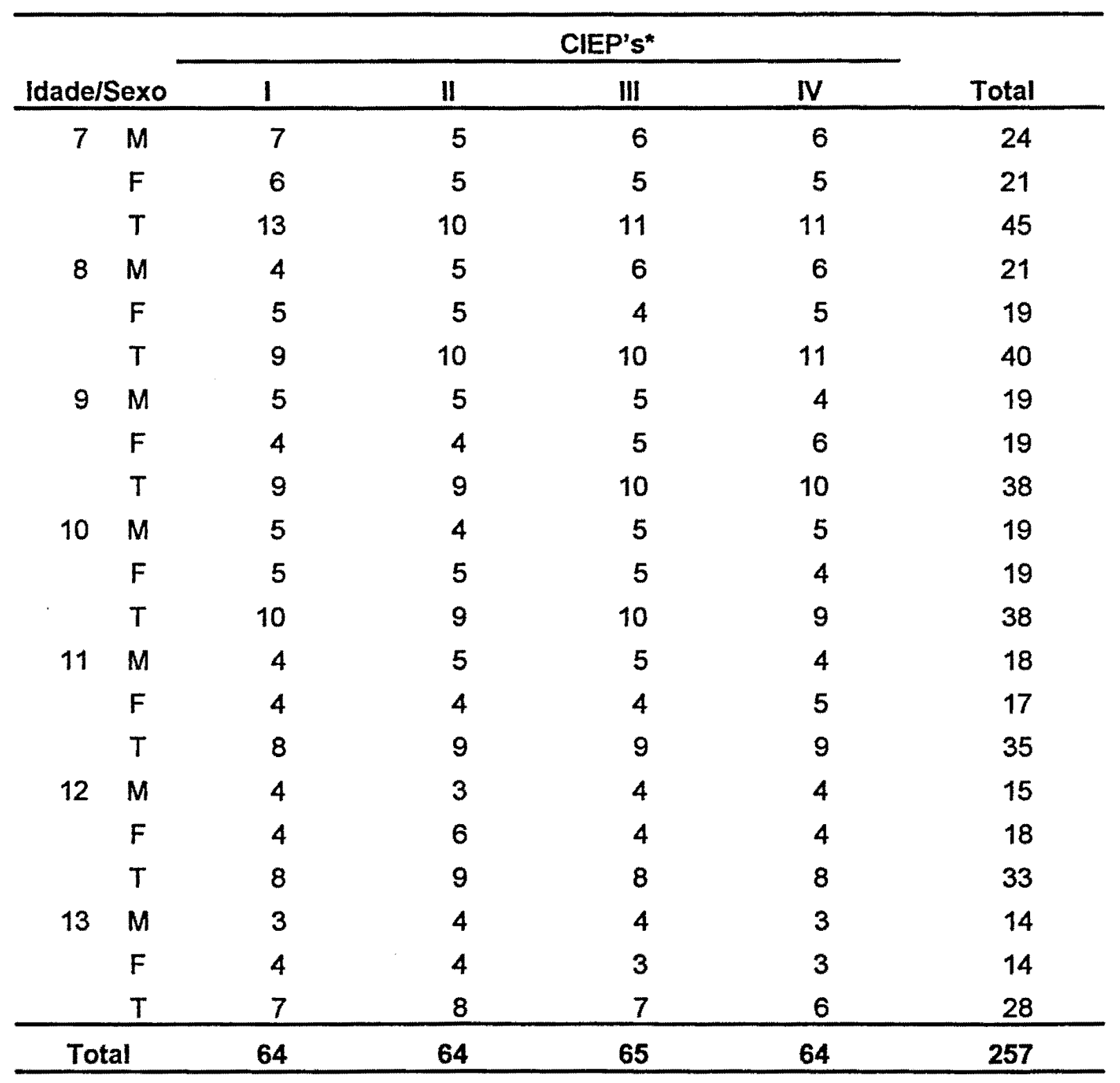

* 1 - CIEP Prof. Octávio C. Borghi

II - CIEP Prof ${ }^{2}$ Philomena M. Bassete

III - CIEP Prof ${ }^{\text {a }}$ Oniva de M. Brizolla

IV-CIEP Prof. Anísio S. Teixeira 


\subsection{MÉTODO}

\subsubsection{Estado Nutricional}

A análise das condições de crescimento de uma população, a partir de dados antropométricos, requer a adoção de um padrão de referência.

Neste estudo, adotou-se o padrão antropométrico NCHS (1976), recomendado pela Organização Mundial da Saúde (WHO, 1986) como padrão internacional de referência. Vale informar que o referido padrão foi adotado pelo Ministério da Saúde, como referência à população brasileira* .

Para cada criança do estudo, foi calculado o índice antropométrico altura para idade (A/).

Justifica-se a adoção da altura da criança em idade escolar como indicador do estado nutricional e das condições de saúde da população em geral, tendo em vista a vulnerabilidade da população infantil aos agravos ambientais e a constatação de que a relação altura para idade nesta faixa etária, resume satisfatoriamente os eventos sociais, econômicos e biológicos ocorridos com a criança desde sua concepção (VALVERDE, 1985).

As categorias nutricionais podem ser definidas com base em percentuais de peso elou altura medianos, número de desvios-padrōes acima ou abaixo da mediana ou percentis da distribuição adotada como padrão.

Segundo WATERLOW e col (1977) e MONTEIRO (1984), em qualquer dessas opçōes, os niveis criticos entre normalidade e distrofia são inevitavelmente estabelecidos de maneira arbitrária.

Em nosso meio tem sido frequente a adoçāo de percentuais do padrão de referência e unidades de desvio padrão, denominado escore $Z$.

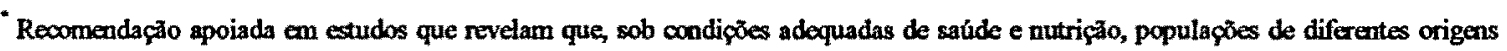
énicas tenden a apresentar padrão semelhante de crescimento durante a infäncia (GRAITCER \& GENTRY, 1981; HABICHT e col, 1974)
} 
Desse modo, adota-se, neste estudo, o critério para classificação com base nas unidades de desvio padrão, ou escores $Z *$ (WHO, 1986).

É usual considerar como "normais" aquelas crianças que distam até dois escores $Z$ da mediana da população de referência. Desse modo, considera-se déficit de crescimento a altura da criança que situar-se abaixo de -2 desvios-padrōes do valor mediano esperado para idade e sexo (WATERLOW, 1977)

O cálculo das idades dos escolares e dos respectivos valores dos escores de altura para idade (ZAI) foram determinados usando-se o programa EPIINFO (versão 5.01b).

Para a obtenção das medidas de peso foi utilizada balança (Marca FILIZOLA) com capacidade até $150,0 \mathrm{~kg}$, e escala com divisões em quilogramas e 100 gramas. A altura foi determinada utilizando-se a régua metálica graduada em centímetros da balança.

\subsubsection{Consumo Alimentar}

O consumo alimentar dos escolares foi obtido pelo registro dos alimentos ingeridos pela criança, durante três dias não consecutivos da semana.

Esse procedimento visou conhecer a variação semanal e também minimizar as possiveis diferenças que pudessem existir nos hábitos alimentares. Sábados e domingos não foram considerados porque nesses dias os CIEP's não mantêm atividades.

De acordo com diversos autores (BASIOTIS e col, 1987; GUNTHRIE \& CROCETTI, 1985; PERSON \& GARLGREN, 1984) três dias de

\footnotetext{
"ESCORE $\mathrm{Z}$ de altura para idade $=\mathrm{ZAI}=$ altura observada - aluura esperada $*$

desvio-padrio

* Observar que se trata de alura mediana que o padrão de referéncia (NCHS, 1976), registra para criangas de mesma idade.
} 
levantamento são suficientes para abranger quantidade e variabilidade de alimentos consumidos por grupos de individuos.

É importante esclarecer que devido a jornada discente integral que limita a saida do aluno da escola, há possibilidade de controle mais eficaz do número de refeiçōes a serem preparadas e consumidas diariamente. Verificouse durante o periodo da pesquisa irrisórias quantidades de sobras limpas (alimentos preparados e não distribuídos) e de restos (alimentos distribuídos e não consumidos).

Tal fato pode ser decorrente de uma prática relatada pelos supervisores do programa que consiste em obter freqüentemente registros sobre os hábitos alimentares das crianças. Indiscutivelmente, informações dessa natureza possibilitam elevar a aceitação às refeições servidas na escola, intervir visando corrigir possiveis erros alimentares e otimizar os serviços, reduzindo desperdícios e distorções na operacionalização do programa.

Os alimentos consumidos, no âmbito dos CIEP's, foram registrados pela autora, em medidas caseiras (Anexo l).

Para a conversão em gramas, dos alimentos registrados em medidas caseiras, utilizaram-se os pesos de medidas caseiras adotados no Programa de Apoio à Decisão em Nutrição (versão 2.0), desenvolvido pelo Centro de Informática em Saúde da Universidade Federal de São Paulo (Escola Paulista de Medicina).

Para o registro do consumo de alimentos, em nível doméstico, dos escolares de 7 e 8 anos de idade, optou-se por solicitar as informaçōes à mãe ou pessoa responsável pela alimentação. Esta preocupação é justificada por autores (KRALL e col, 1988; MADDEN e col, 1976) que apontam para limitaçōes da memória das crianças, principalmente das mais jovens. Segundo esses autores, com grande frequência as crianças erram detalhes e confundem eventos imaginários com reais.

A partir das informações relativas às quantidades dos alimentos, foi possivel elaborar cálculos visando a avaliação da ingestão de calorias e 
nutrientes. Para tanto, utilizou-se a Tabela de Composição de Alimentos do Instituto Brasileiro de Geografia e Estatística - FIBGE (1977).

\subsubsection{Adequação do Consumo Alimentar}

Para obter a adequaçăo média da dieta dos escolares investigados, adotou-se como parâmetro as recomendações diarias de energia e nutrientes, proposto por MARTINS \& HIDALGO (1983).

Ressalta-se que os autores estabeleceram as recomendações de energia e nutrientes para a população brasileira, "considerando, na medida do possivel, fatores referentes à qualidade de dietas brasileiras e às infecções crônicas constantemente encontradas no Pais".

Tendo em vista que as recomendações de energia e proteinas estão relacionadas diretamente com o peso corporal do indivíduo, tomaram-se como base os valores definidos por MARTINS \& HIDALGO (1983), calculando-se os dados de energia e proteinas para as crianças, de ambos os sexos e idades entre 7 e 13 anos, utilizando-se peso corporal do $50^{\circ}$ percentil do padrão de referência NCHS (1976). Os valores obtidos são apresentados na TABELA 3. 
TABELA 3. Valores de energia e proteínas, por quilograma de peso corporal, para as idades de 7 a 13 anos e ambos os sexos.

\begin{tabular}{|c|c|c|c|c|}
\hline \multicolumn{2}{|c|}{$\begin{array}{c}\text { Idade/Sexo } \\
\text { (anos) }\end{array}$} & \multirow{2}{*}{$\begin{array}{c}\text { Peso Corporal } \\
\text { (kg) }\end{array}$} & \multirow{2}{*}{$\begin{array}{c}\begin{array}{c}\text { Energia }^{* *} \\
\text { (kcal/kg de peso) }\end{array} \\
83\end{array}$} & \multirow{2}{*}{$\begin{array}{c}\begin{array}{c}\text { Proteína }^{* *} \\
\text { (g/kg de peso) }\end{array} \\
1,74\end{array}$} \\
\hline 7 & $M$ & & & \\
\hline & $\mathrm{F}$ & 21,84 & 80 & 1,74 \\
\hline \multirow[t]{2}{*}{8} & M & 25,30 & 79 & 1,66 \\
\hline & $F$ & 24,84 & 76 & 1,66 \\
\hline \multirow[t]{2}{*}{9} & M & 28,13 & 76 & 1,58 \\
\hline & $F$ & 28,46 & 73 & 1,58 \\
\hline \multirow[t]{2}{*}{10} & $M$ & 31,44 & 74 & 1,52 \\
\hline & $F$ & 32,55 & 68 & 1,46 \\
\hline \multirow[t]{2}{*}{11} & $M$ & 35,30 & 71 & 1,46 \\
\hline & $\mathrm{F}$ & 36,96 & 62 & 1,38 \\
\hline \multirow[t]{2}{*}{12} & $M$ & 39,78 & 67 & 1,42 \\
\hline & $F$ & 41,53 & 57 & 1,31 \\
\hline \multirow[t]{2}{*}{13} & $M$ & 44,95 & 61 & 1,35 \\
\hline & $F$ & 46,10 & 52 & 1,26 \\
\hline
\end{tabular}

* $50^{\circ}$ PERCENTIL do Padrão de Referência - NCHS (1976)

* Valores recomendados por MARTINS \& HIDALGO (1983)

Faz-se necessário considerar que a tiamina, riboflavina e niacina estão na dependência do total energético da dieta. Desse modo, as recomendações para esses nutrientes foram calculadas, baseando-se nos valores de energia obtidos previamente (TABELA 3).

Assim, resultaram as recomendações de energia e dos vários nutrientes, calculados especificamente para o grupo de escolares investigados, cujos dados são apresentados a seguir (TABELA 4). 
TABELA 4. Recomendações de energia e nutrientes, baseadas nas recomendações nutricionais para a população brasileira*, adaptadas por anos de idade, segundo sexo e peso corporal.

\begin{tabular}{|c|c|c|c|c|c|c|c|c|c|}
\hline Idade/Sexo & $(\text { kcal })^{\star \star}$ & Proteína & $(\mu \mathrm{ER})$ & Tiamina & $\begin{array}{c}\text { Ribofla- } \\
\text { vina } \\
\text { (mg) }\end{array}$ & Niacina & $\begin{array}{l}\text { Ácido } \\
\text { ascór- } \\
\text { bico } \\
\text { (mg) }\end{array}$ & (mg) & $(\mathrm{mg})$ \\
\hline $7 \mathrm{M}$ & 1.900 & 39 & 400 & 0.76 & 1.05 & 12.54 & 20 & 450 & 10 \\
\hline $\mathbf{F}$ & 1.750 & 38 & 400 & 0.70 & 0.96 & 11.55 & 20 & 450 & 10 \\
\hline $8 M$ & 2.000 & 42 & 400 & 0.80 & 1.10 & 13.20 & 20 & 450 & 10 \\
\hline$F$ & 1.890 & 41 & 400 & 0.76 & 1.04 & 12.47 & 20 & 450 & 10 \\
\hline $9 M$ & 2.200 & 44 & 400 & 0.88 & 1.21 & 14.52 & 20 & 450 & 10 \\
\hline$F$ & 2.100 & 45 & 400 & 0.84 & 1.16 & 13.86 & 20 & 450 & 10 \\
\hline $10 \mathrm{M}$ & 2.350 & 48 & 575 & 0.94 & 1.29 & 15.51 & 20 & 650 & 10 \\
\hline$F$ & 2.250 & 48 & 575 & 0.90 & 1.24 & 14.85 & 20 & 650 & 10 \\
\hline $11 \mathrm{M}$ & 2.500 & 52 & 575 & 1.00 & 1.38 & 16.50 & 20 & 650 & 10 \\
\hline$F$ & 2.300 & 51 & 575 & 0.92 & 1.27 & 15.18 & 20 & 650 & 10 \\
\hline $12 \mathrm{M}$ & 2.700 & 57 & 575 & 1.10 & 1.49 & 17.82 & 20 & 650 & 10 \\
\hline $\mathbf{F}$ & 2.400 & 54 & 575 & 0.96 & 1.32 & 15.84 & 20 & 650 & 10 \\
\hline $13 \mathrm{M}$ & 2.750 & 61 & 725 & 1.21 & 1.51 & 18.15 & 30 & 650 & 18 \\
\hline $\mathbf{F}$ & 2.500 & 581 & 725 & 1.00 & 1.38 & 16.50 & 30 & 650 & 24 \\
\hline
\end{tabular}

* martins \& hidalgo (1983)

* Foram feitos arredondamentos no algarismo referente a dezenas de calorias e a gramas de protelnas tendo em vista que variaçöes de ordem de grandeza não tếm significado prático.

Serão considerados adequados os valores de energia e nutrientes da dieta dos escolares que atingirem $100 \%$ das recomendações nutricionais.

\subsubsection{Caracteristicas Sócio-Econômicas}

Antecedendo à fase de colheita de dados, preocupou-se em esclarecer às crianças e respectivas familias sobre os objetivos do estudo. 
O levantamento dos dados foi realizado por técnicos em nutrição e enfermagem, previamente treinados pela autora, mediante entrevista realizada na própria escola com a mãe ou responsável. Os dados foram registrados em formulário, planejado especialmente para o estudo em questão (Anexo II), prétestado em população semelhante, não pertencente à amostra.

Através do formulário foram colhidas informações, que são sinteticamente descritas a seguir:

- Renda familiar: obtida considerando-se a soma dos rendimentos de cada morador que contribua para o conjunto das despesas da casa. Foram incluidos rendimentos provenientes de pensão, aposentadoria, aluguel. A renda per capita foi obtida dividindo-se o resultado pelo número de moradores.

- Nivel de escolaridade: obteve-se informaçōes relativas a mãe. A escolaridade foi definida, adotando-se as modalidades: analfabeto - sem estudo e os anos de estudos, especificando a série alcançada.

- Ambiente físico: para a caracterização do ambiente físico em que viviam as crianças, foram obtidas informações sobre as condiçōes do saneamento ambiental (tipo de abastecimento de água: torneira em casa, torneira coletiva, poço, fonte, outros). As condiçōes sanitárias foram levantadas a partir das modalidades: rede geral de esgoto, fossa séptica, fossa negra, outros. Quanto à caracterização das condiçōes de habitação, classificaramse os escolares segundo a moradia em casas de alveraria e não-alvenaria.

- Frequência à creche: foi considerado a condição da criança ter ou não frequentado creche elou pré-escola durante a idade pré-escolar. 


\section{RESULTADOS E DISCUSSÃO}

\subsection{ESTADO NUTRICIONAL}

A partir das medidas antropométricas obteve-se o escore $Z$ (número de unidades de desvios-padrões em que se encontra a medida antropométrica da criança em relação ao valor esperado da população de referência), do indice antropométrico altura para idade (ZAl).

Serão distinguidos três intervalos de valores de ZAl: menor que -2 , de -2 a menos que -1 e pelo menos igual $a-1$.

Em uma população com boas condições de saúde e nutrição, aproximadamente, $2,3 \%$ dos valores estarão no primeiro intervalo, $13.6 \%$ estarão no segundo intervalo e os restantes $84,1 \%$ deverăo ter $Z A I \geq-1$. Se em um determinado grupo de crianças for constatado que a proporção com $Z$ de altura para idade inferior a -2 é substancialmente superior a $2,3 \%$, tem-se um indicador de que as condições de saúde e nutrição são inadequadas, o que está sempre associado à pobreza da população analisada.

A proporção de crianças com ZAI < -2 pode ser utilizada, então, como indicador de desnutrição crônica. A proporção de crianças com $-2 \leq \mathrm{ZAI}<-1$, caso seja elevada, indica uma situação de desnutrição leve. As demais situações, com ZAI $\geq-1$, correspondem à eutrofia.

Para tornar possível o cálculo do qui-quadrado de tendência linear de Mantel-Haenszel, em alguns casos foram elaboradas tabelas com apenas 
dois niveis de escore $Z$ de altura para idade: $Z A I<-2$ e $Z A I \geq-2$. 0 procedimento será adotado para análise das tabelas que envolvem o nivel de renda e escolaridade da mãe. O qui-quadrado comum destina-se a captar qualquer tipo de relação entre as duas variáveis utilizadas na elaboração de tabelas de contingência. Por outro lado, o qui-quadrado da tendência linear destina-se a detectar a existência de tendência de crescimento ou diminuiçāo da proporção de desnutridos crônicos $(Z A l<-2)$ em função do nivel da outra variável considerada, que no caso será a renda ou escolaridade da mäe. Sendo um teste com uma finalidade mais especifica o qui-quadrado de tendência linear é mais poderoso que o qui-quadrado comum.

A amostra envolveu 257 crianças para as quais foram obtidas diversas informaçōes, conforme descrito anteriormente.

$\dot{E}$ interessante ressaltar que foram tomadas medidas antropométricas para a totalidade de crianças pertencentes à amostra.

Inicialmente serão apresentadas as análises do indice antropométrico altura para idade (ZAl) das crianças.

$\mathrm{Na}$ TABELA 5, encontram-se os resultados da classificação do estado nutricional das crianças conforme CIEP de origem.

TABELA 5. Distribuição das crianças em três categorias do estado nutricional, com base no escore $Z$ de alturalidade (ZAI), conforme CIEP. Americana, 1994.

\begin{tabular}{|c|c|c|c|c|c|}
\hline \multirow[b]{2}{*}{ CIEP } & \multicolumn{2}{|c|}{ CRIANÇAS } & \multicolumn{3}{|c|}{ CATEGORIAS DO ESTADO NUTRICIONAL } \\
\hline & $\mathbf{N}^{0}$ & $\%$ & $\begin{array}{c}\mathrm{ZAI}<-2 \\
(\%)\end{array}$ & $\begin{array}{c}-2 \leq Z A \mid<-1 \\
(\%)\end{array}$ & $\begin{array}{c}Z A \mid \geq-1 \\
(\%)\end{array}$ \\
\hline 1 & 64 & 24,9 & 26,6 & 32,8 & 40,6 \\
\hline II & 64 & 24,9 & 12,5 & 45,3 & 42,2 \\
\hline III & 65 & 25,3 & 20,0 & 21,5 & 58,5 \\
\hline IV & 64 & 24,9 & 3,1 & 45,3 & 51,6 \\
\hline TOTAL & 257 & 100,0 & 15,6 & 36,2 & 48,3 \\
\hline
\end{tabular}


Pode-se perceber pelos dados da TABELA 5 que a menor proporção de crianças desnutridas é verificada no CIEP IV. A proporção está muito próxima da distribuição de referência, sendo indicativa de que as crianças observadas $(Z A I \geq-1)$ estão expostas a melhores condições de saúde e nutrição.

Proporções excessivas de crianças com ZAl $<-2$ são observadas nos CIEP I (26,6\%) e III $(20,0 \%)$. É interessante notar que a prevalência de déficits de altura nesses CIEP's é muito superior à observada por MONDINI (1990) entre crianças de escolas públicas de Rio Claro. A autora verificou que a prevalência de desnutridos crônicos no município, situado na região de Americana, oscilava entre $3,7 \%$ e $12,6 \%$. Proporçōes de crianças consideradas intermediárias são observadas no ClEP $\|$, onde se constatou proporção de $12,5 \%$ de desnutridos crônicos.

Com referência à prevalência de crianças com $Z A I \geq-1$, definidas nesta pesquisa como eutróficas, observa-se que as maiores proporções são encontradas nos CIEP's III $(58,5 \%)$ e IV $(51,6 \%)$. Inversamente, os menores percentuais de crianças, nessa categoria, foram encontrados nos CIEP'S I $(40,6 \%)$ e II $(42,2 \%)$. Todas essas proporçōes distam substancialmente da esperada $(84,1 \%)$.

Ressalta-se que essas diferenças são estatisticamente significantes, como mostra o teste de qui-quadrado, $x^{2}=22,4$, com seis graus de liberdade.

Os resultados seguem de maneira bastante próxima os dados de altura das crianças brasileiras do setor urbano da Região Sudeste, obtidos através da PNSN (MONTEIRO e col, 1992). De acordo com as análises, os jovens brasileiros apresentam maior desvantagem de altura do que de peso quando comparados ao padrão de referência. $\mathrm{Na}$ área urbana da região sudeste, as diferenças, embora menores que na área rural, são de 5 centímetros para as mulheres aos 13 anos e 6 para os homens aos 14 anos. 
É oportuno destacar que as implicações do retardo no crescimento têm sido alvo de intensos debates (BEATON, 1989; WATERLOW, 1991).

Vale ressaltar as indesejáveis repercussões do retardo no crescimento dos indivíduos, principalmente nos paises mais pobres, onde os rendimentos, frequentemente, são obtidos através de trabalho humano que demandam grande capacidade física e alto gasto energético.

Estudo de SPURR (1988) ressaltou que a capacidade física para o trabalho depende do estado nutricional, verificando que os agricultores desnutridos apresentaram menor capacidade física e menor produtividade como consequência da diminuição da massa muscular.

No Brasil, onde grande parte dos trabalhadores realizam atividades profissionais que requerem esforço físico muscular, a repercussão orgânica do trabalho de indivíduos desnutridos pode assumir proporções calamitosas.

ANJOS (1993), analisando dados da PNSN, constatou que a curva de déficit de estatura das crianças com pais que trabalham com esforço físico intenso é maior do que aquelas cujos progenitores têm atividades mais suaves, apesar de todas apresentarem, em média, déficits de estatura. Enfatiza, também, que são os trabalhadores com maior atividade física ocupacional que apresentam as piores condições de vida, caracterizada por menor renda, nivel mais baixo de instrução e piores condições de moradia. À semelhança do que ocorre com seus pais, as crianças com maiores déficits de crescimento entram cedo no mercado de trabalho e fatalmente acabarão no setor que exige menor capacitaçāo de mão-de-obra, associado à ocupação com grande esforço físico. O autor apresenta dados referentes à resposta da frequência cardiaca à carga física de crianças de 8 e 9 anos da baixada fluminense, matriculadas em CIEP's, cujas condições de vida eram bastante precárias. Conclui que para uma mesma carga (45 watt), crianças com déficit de estatura respondem com uma frequência cardiaca de cerca de 20 batimentos por minuto $(\mathrm{bpm})$ a mais do que aquelas sem déficit de crescimento, atingindo, respectivamente, $165 \mathrm{e}$ $145 \mathrm{bpm}$. 
Desse modo, crianças com déficits de crescimento para realizar o mesmo trabalho físico do que outra sem déficit, são submetidas a uma sobrecarga cardiovascular maior.

Há muita polêmica em torno da relação existente entre o estado nutricional e o desempenho escolar.

Existem críticas ao processo de "medicalização do processo escolar", que tenta explicar a situação sob a ótica das causas e soluções médicas ignorando, na maioria das vezes, os condicionantes sociais do problema.

Contudo, POLLITT (1988) aponta para a signicativa redução do gasto energético, com destaque para a atividade motora, de crianças desnutridas. $O$ autor ressalta que crianças com história de desnutrição que tenham sobrevivido sem ter atendidas plenamente suas necessidades fisiológicas e sócio-econômicas básicas têm maior probabilidade de ter baixo rendimento ou de experimentar fracasso escolar do que outras do mesmo nivel sócio-econômico.

LEI (1994), estudando escolares do municipio de Osasco, demonstrou que a exposiçāo a déficit de crescimento na idade pré-escolar determinou prognóstico de "reprovação" em termos de aproveitamento escolar duas vezes maior do que o observado entre alunos sem retardo do crescimento. Ainda, de acordo com a autora, o controle de variáveis sócio econômicas amenizou, contudo, não eliminou o pior prognóstico escolar dos ingressantes com retardo do crescimento.

Tendo em vista que a pesquisa busca contribuir para a discussão acerca dos condicionantes do estado nutricional, apresenta-se, a seguir, a análise da influência de alguns fatores sobre os indices antropométricos dos alunos matriculados nos quatro CIEP's de Americana. Vale lembrar que a amostra constituiu-se, inicialmente, de 257 crianças.

Os fatores considerados são: renda familiar per capita, escolaridade da mãe, tipo de abastecimento de água no domicílio, modalidade de esgoto, 
condições da habitação (alvenaria ou não), e o fato da criança ter ou não frequentado creche. Assim, foi necessário excluir as crianças para as quais não se obteve informações para algum dos referidos fatores, totalizando 242 crianças na amostra. Verifica-se que há duas crianças para as quais a renda familiar declarada é igual a zero. Uma vez que nas análises será utilizado o logaritmo da renda (que não se define para renda nula), optou-se por considerar as 240 observaçōes com renda familiar per capita positiva.

As dificuldades e os custos inerentes a alguns tipos de estudos epidemiológicos impõem uma série de restrições à sua realização em nosso meio. Por essa razão, praticamente a totalidade das informações diponiveis especificamente sobre o estado nutricional de crianças brasileiras é obtida através de estudos transversais e prospectivos.

Nesta pesquisa optou-se pela realização de estudo transversal. $\dot{E}$ pertinente destacar que mesmo com algumas limitações inerentes ao tipo de delineamento adotado, a quantificação dos dados possibilitou as estimativas de riscos a que o grupo de escolares matriculados nos CIEP's estavam expostos no momento da pesquisa.

Sabe-se que o indicador altura para idade (variável dependente) resume os eventos sócio-econômicos e biológicos ocorridos com a criança desde a sua concepção. É razoável supor, entretanto, que as condiçōes de vida observadas no momento da pesquisa são semelhantes àquelas enfrentadas pelas crianças na sua vida pregressa, inclusive nos primeiros dois anos, considerados particularmente criticos para o crescimento $e$ desenvolvimento infantil.

Utilizou-se, nesta pesquisa, a renda familiar que expressa melhor a disponibilidade de recursos, pois leva em consideração o número de pessoas que teoricamente dividem a renda.

A seguir apresenta-se a análise tabular dos dados estatísticos.

Na TABELA 6, são apresentados os resultados da classificação das crianças quanto aos estratos de renda e categorias de estado nutricional. 
TABELA 6. Número e percentagem de crianças em cinco estratos de renda familiar per capita, segundo categorias do estado nutricional. Americana, 1994.

\begin{tabular}{c|c|c|c|c|c}
\hline $\begin{array}{c}\text { ESTRATO DE } \\
\text { RENDA } \\
\text { FAMILIAR } \\
\text { (REAIS PER } \\
\text { CAPITA) }\end{array}$ & \multicolumn{2}{|c|}{ CRIANÇAS } & \multicolumn{3}{|c}{$\begin{array}{c}\text { CATEGORIAS DO ESTADO } \\
\text { NUTRICIONAL }\end{array}$} \\
\cline { 2 - 6 } & $N^{\circ}$ & $\%$ & $\begin{array}{c}\text { ZAI }<-2 \\
(\%)\end{array}$ & $\begin{array}{c}-2 \leq \text { ZAI }<-1 \\
(\%)\end{array}$ & $\begin{array}{c}\text { ZAI } \geq-1 \\
(\%)\end{array}$ \\
\hline$<25$ & 50 & 20,8 & 26,0 & 38,0 & 36,0 \\
$25 \vdash 50$ & 82 & 34,2 & 15,8 & 35,4 & 48,8 \\
$50 \vdash 75$ & 39 & 16,2 & 23,1 & 43,6 & 33,3 \\
$75 \vdash 100$ & 29 & 12,1 & 3,4 & 44,8 & 51,7 \\
$\geq 100$ & 40 & 16,7 & 5,0 & 17,5 & 77,5 \\
\hline TOTAL & $\mathbf{2 4 0}$ & $\mathbf{1 0 0 , 0}$ & $\mathbf{1 5 , 8}$ & $\mathbf{3 5 , 4}$ & $\mathbf{4 8 , 8}$ \\
\hline
\end{tabular}

Verifica-se que, à medida que aumenta a renda, tende a diminuir a percentagem de crianças $\operatorname{com} Z<-2$ e aumentar a percentagem $\operatorname{com} Z \geq-1$. A tabela de contingência com os 5 estratos de renda e três niveis de $Z$ de altura para idade $(Z<-2,-2 \leq Z<-1$ e $Z \geq-1)$ leva a um qui-quadrado igual a 25,91, com 8 graus de liberdade, significativo ao nivel de $1 \%$, indicando que há forte associação entre essas duas variáveis.

Os resultados apresentados são confirmados pela análise do risco relativo de desnutrição conforme mostra a tabela 7 . 
TABELA 7. Prevalência de desnutriçao crônica entre escolares, conforme renda familiar per capita. Americana, 1994.

\begin{tabular}{c|c|c|c}
\hline $\begin{array}{c}\text { ESTRATO DE } \\
\text { RENDA FAMILIAR } \\
\text { (REAIS per capita) }\end{array}$ & $\begin{array}{c}\text { NÚMERO DE } \\
\text { CRIANÇAS COM } \\
\text { ZAI<-2 }\end{array}$ & $\begin{array}{c}\text { PREVALÊNCIA DA } \\
\text { DESNUTRIÇÄO } \\
\text { CRÓNICA (ZAI <-2) } \\
(\%)\end{array}$ & $\begin{array}{c}\text { RISCO } \\
\text { RELATIVO }\end{array}$ \\
\hline$<25$ & 13 & 26,0 & 5,2 \\
$25 \vdash 50$ & 13 & 15,9 & 3,2 \\
$50 \vdash 75$ & 9 & 23,1 & 4,6 \\
$75 \vdash 100$ & 1 & 3,5 & 0,7 \\
$\geq 100$ & 2 & 5,0 & 1,0 \\
\hline TOTAL & 38 & $\mathbf{1 5 , 8}$ & \\
\hline
\end{tabular}

A TABELA 7 mostra uma clara associação entre renda per capita e a prevalência de desnutrição crônica. $O$ qui-quadrado de tendência linear de Mantel-Haenszel é 8,39 com um grau de liberdade, significativo a $1 \%$.

Note-se que os escolares pertencentes a familias de baixa renda (<25 reais per capita) apresentam aproximadamente 5 vezes mais risco de desnutrição crônica do que o grupo com renda familiar per capita mais alta $(\geq 100$ reais).

Os dados obtidos nesta pesquisa são concordantes com a PNSN (INAN, 1990) que revelou a forte influência exercida pela renda familiar sobre o padrão de crescimento das crianças brasileiras.

Observa-se, nas tabelas 6 e 7, que entre as 50 crianças com renda familiar per capita inferior a 25 reais há 13 com escore-ZAl $<-2$. Assim o risco de desnutrição crônica nesse estrato de renda é $13 / 50=0,26$ ou $26 \%$. No estrato mais rico, o risco de desnutrição crônica é $2 / 40=0,05$ ou $5 \%$. Desse modo, o risco relativo de desnutrição crônica no estrato mais pobre é $26 / 5=$ 5,2 . Os demais valores de risco relativo apresentados na última coluna da tabela 7 são calculados de maneira análoga, sempre tendo por base o risco de 
desnutrição crônica no estrato com renda familiar per capita igual ou superior a 100 reais.

É importante destacar que estudos regionais realizados no estado do Rio de Janeiro, no interior do estado de São Paulo e Distrito Federal, também apontam para a estreita relação entre o estado nutricional infantil e a renda familiar.

ANJOS e col. (1989), analisando indicadores de gordura corporal de 437 escolares ( 7 a 11 anos de idade) que viviam em condiçōes ambientais distintas na cidade do Rio de Janeiro, constataram que crianças de origem menos privilegiada apresentaram massa corporal, estatura e área de gordura muscular do braço significativamente inferiores às das crianças de classe social mais privilegiada. Os dados sugerem que desnutrição energéticoprotéica é prevalente entre crianças de baixo nivel sócio-econômico enquanto o excesso de massa corporal e de gordura ocorrem, com maior frequência, em crianças de mais alto nivel sócio-econômico.

SOARES e col (1993) observaram 343 escolares (6 a 16 anos), matriculados em um CIEP do estado do Rio de Janeiro, segundo o índice antropométrico altura/idade adotando como nivel crítico o $10^{\circ}$ percentil. Os autores constataram que $26,2 \%$ das crianças eram consideradas desnutridas crônicas, mais que o dobro da proporção esperada (10\%).

BARROS e col (1990) realizaram estudo considerando amostra estratificada de $10 \%$ das crianças, da $1^{\text {a }}$ série do $1^{\circ}$ grau, do municipio de Campinas, estado de São Paulo. As 1942 crianças pertenciam a escolas que foram divididas em 4 estratos sócio-econômicos (alto, médio, baixo e muito baixo). Foram observadas diferenças de $3,6 \mathrm{~cm}$ e $5,3 \mathrm{~cm}$ nas médias de altura, respectivamente, entre os niveis sócio-econômicos alto e baixo. Os autores encontraram variação significativa desse índice antropométrico em função do nível sócio-econômico (baseado no tipo de escola particular ou pública e pelas características da área onde se localiza a escola). Riscos do escolar vir a ser "stunted", de baixo peso, ou "wasted" foi associado com nível sócio-econômico. 
Estudo de FURUMOTO e col (1993), avaliando o estado nutricional de 175 crianças da faixa etária de 6 a 14 anos, matriculadas em escola pública do Distrito Federal, concluiu que $17 \%$ da população apresentava inadequação do peso para idade, situando-se abaixo do $10^{\circ}$ percentil. Quanto aos déficits de altura, verificou-se que $19 \%$ das crianças situavam-se abaixo do referido nivel crítico.

Com relação aos prejuizos funcionais, TOMKINS (1988), citado por LEI (1994), fez uma revisão da literatura sobre a relação existente entre baixa estatura e risco subsequente de morbidade e mortalidade. As evidências demonstram que crianças "stunded", ou seja, que apresentam déficit de estatura, têm infecçōes por periodo mais prolongado e alto índice de mortalidade associado a infecções. As condições sócio-econômicas e ambientais explicam as razōes que condicionam a não adequação do consumo de alimentos para que a criança "stunted" possa alcançar seu potencial genético quanto ao crescimento linear. Retardo de crescimento é mais comumente observado em crianças provenientes de familias de baixa renda, estando expostas não só no que diz respeito à qualidade e quantidade de alimentos ingeridos, como também habitação, saneamento, grau de instrução dos pais e acesso aos serviços de saúde. Como consequência, há a interação de fatores sociais na relação existente entre duração da doença e "stunting".

Quanto ao papel do nivel de escolaridade na determinação do estado nutricional das crianças, lembra-se que maior nivel de escolaridade pode contribuir, entre outros fatores, para melhor utilização de serviços públicos de saúde e para a identificação e seleção de alimentos ricos em nutrientes. Indiretamente a escolaridade atua na medida em que ela esteja relacionada às maiores chances de participação no mercado de trabalho e de receber salários mais altos.

$E$ interessante mencionar que $28,3 \%$ das familias dos escolares amostrados são chefiadas por mulheres. A situação condiciona freqüentemente uma maior mobilização dos membros dessas familias sugerindo que, dado os 
diferenciais de rendimento entre os sexos vigentes na nossa sociedade, a chefia feminina gera a necessidade de que crianças e adolescentes também colaborem para a composição da renda familiar. O fato concorre para um prejuizo para as crianças que devido ao ingresso precoce no mercado de trabalho, têm dificuldades para freqüentarem a escola de tempo integral.

A TABELA 8 mostra os resultados da classificação das crianças, segundo os niveis de escolaridade da mãe e categorias do estado nutricional.

TABELA 8. Número e percentagem de crianças em cinco niveis de escolaridade da mãe, segundo categorias do estado nutricional. Americana, 1994.

\begin{tabular}{|c|c|c|c|c|c|}
\hline \multirow{2}{*}{$\begin{array}{c}\text { NIVEIS DE } \\
\text { ESCOLARIDA } \\
\text { DE DA MĀE } \\
\text { (ANOS) }\end{array}$} & \multicolumn{2}{|c|}{ CRIANÇAS } & \multicolumn{3}{|c|}{$\begin{array}{c}\text { CATEGORIAS DO ESTADO } \\
\text { NUTRICIONAL }\end{array}$} \\
\hline & No & $\%$ & $\begin{array}{c}Z A I<-2 \\
(\%)\end{array}$ & $\begin{array}{c}-2 \leq \mathrm{ZAI}<-1 \\
(\%)\end{array}$ & $\begin{array}{c}Z A I \geq-1 \\
(\%)\end{array}$ \\
\hline SEM ESTUDO & 10 & 4,2 & 20,0 & 30,0 & 50,0 \\
\hline 1 a 3 & 56 & 23,3 & 19,6 & 39,3 & 41,1 \\
\hline 4 & 71 & 29,6 & 19,7 & 35,2 & 45,1 \\
\hline 5 a 8 & 29 & 32,9 & 11,4 & 30,4 & 58,2 \\
\hline 9 ou mais & 24 & 10,0 & 8,3 & 45,8 & 45,8 \\
\hline TOTAL & 240 & 100,0 & 15,8 & 35,4 & 48,8 \\
\hline
\end{tabular}

$X^{2}=7,13$, com 8 graus de liberdade, não-significativo.

Observa-se que a proporção de crianças com escore-Z (altura/idade) $<-2$ tende a diminuir quando aumenta a escolaridade da mãe.

A TABELA 9 apresenta a análise de risco de desnutrição conforme os niveis de escolaridade da mãe. 
TABELA 9. Prevalência de desnutrição crônica entre escolares, conforme niveis de escolaridade da mãe. Americana, 1994.

\begin{tabular}{c|c|c|c}
\hline $\begin{array}{c}\text { NIVEIS DE } \\
\text { ESCOLARIDADE } \\
\text { DA MÃE (ANOS) }\end{array}$ & $\begin{array}{c}\text { NÜMERO DE } \\
\text { CRIANÇAS COM } \\
\text { ZAI<-2 }\end{array}$ & $\begin{array}{c}\text { PREVALÊNCIA DA } \\
\text { DESNUTRIÇÄO } \\
\text { CRÔNICA (ZAI<-2) } \\
(\%)\end{array}$ & $\begin{array}{c}\text { RISCO } \\
\text { RELATIVO }\end{array}$ \\
\hline sem estudo & 2 & 20,0 & 2,4 \\
1 a 3 & 11 & 19,6 & 2,4 \\
4 & 14 & 19,7 & 2,4 \\
5 a 8 & 9 & 11,4 & 1,4 \\
$\geq 9$ & 2 & 8,3 & 1 \\
\hline TOTAL & 38 & 15,8 & \\
\hline
\end{tabular}

Note-se que as crianças cujas mães possuem no máximo quatro anos de estudo apresentam risco de desnutrição crônica 2,4 vezes maior do que aquelas cujas mães têm escolaridade igual ou superior a 9 anos.

A associação estatística entre estado nutricional e nível de escolaridade da māe revelou um qui-quadrado de tendência linear de MantelHaenszel de 2,99, com 1 grau de liberdade, significativo a $10 \%$.

Cabe ressaltar que para esse caso o qui-quadrado de tendência linear mostra significância estatística de uma relação que não havia sido captada através do qui-quadrado comum, apresentado na TABELA 8.

É amplamente documentada na literatura a forte influência que o meio ambiente excerce sobre o estado de saúde principalmente de crianças (GOLDING, 1986; JOHNSON, 1981; MONTEIRO \& BENICIO, 1981).

As características do abastecimento de água, tipo de esgoto e moradia são apresentadas nas TABELAS 10,11 e 12.

Na TABELA 10 apresenta-se a classificação do estado nutricional das crianças conforme o tipo de abastecimento de água. 
TABELA 10. Número e percentagem de crianças segundo 0 abastecimento de água no domicílio e categoria do estado nutricional. Americana, 1994.

\begin{tabular}{|c|c|c|c|c|c|}
\hline \multirow{2}{*}{$\begin{array}{c}\text { ABASTECIMENTO } \\
\text { DE } \\
\text { ÁGUA }\end{array}$} & \multicolumn{2}{|c|}{ CRIANÇAS } & \multicolumn{3}{|c|}{$\begin{array}{c}\text { CATEGORIAS DO ESTADO } \\
\text { NUTRICIONAL }\end{array}$} \\
\hline & $\mathbf{N}^{0}$ & $\%$ & $\begin{array}{c}Z A \mid<-2 \\
(\%)\end{array}$ & $\begin{array}{c}-2 \leq Z A \mid<-1 \\
(\%)\end{array}$ & $\begin{array}{c}\mathrm{ZAI} \geq-1 \\
(\%)\end{array}$ \\
\hline $\begin{array}{l}\text { TORNEIRA EM CASA } \\
\text { TORNEIRA }\end{array}$ & 192 & 80,0 & 15,1 & 32,2 & 52,6 \\
\hline $\begin{array}{l}\text { COLETIVA } \\
\text { POÇO, FONTE, }\end{array}$ & 33 & 13,6 & 24,2 & 54,6 & 21,2 \\
\hline OUTRAS FORMAS & 15 & 6,3 & 6,7 & 33,3 & 60,0 \\
\hline TOTAL & 240 & 100,0 & 15,8 & 35,4 & 48,8 \\
\hline
\end{tabular}

$X^{2}=12,40$, com 4 graus de liberdade, significativo a $5 \%$.

A situação quanto ao abastecimento de água pode ser considerada relativamente favorável. De acordo com a TABELA 10 a grande maioria (80\%) das crianças dispunham de água encanada no domicílio. Verifica-se que $15,1 \%$ das crianças pertencem à categoria com ZAl <-2. A situação revelou-se claramente desfavorável para aquelas cuja familia utilizava torneira coletiva: $24,2 \%$ apresentaram escore $Z$ (altura/idade) $<-2$.

TABELA 11. Número e percentagem de crianças segundo o tipo de esgoto doméstico e categoria do estado nutricional. Americana, 1994.

\begin{tabular}{|c|c|c|c|c|c|}
\hline \multirow{2}{*}{$\begin{array}{l}\text { TIPO DE } \\
\text { ESGOTO }\end{array}$} & \multicolumn{2}{|c|}{ CRIANÇAS } & \multicolumn{3}{|c|}{$\begin{array}{l}\text { CATEGORIAS DO ESTADO } \\
\text { NUTRICIONAL }\end{array}$} \\
\hline & $\mathrm{N}^{0}$ & $\%$ & $\begin{array}{c}Z A \mid<-2 \\
(\%)\end{array}$ & $\begin{array}{c}-2 \leq Z \mathrm{ZAI}<-1 \\
(\%)\end{array}$ & $\begin{array}{c}Z \mathbf{Z A} \geq-1 \\
(\%)\end{array}$ \\
\hline REDE GERAL & 197 & 82,1 & 14,7 & 33,0 & 52,3 \\
\hline SEM ESGOTO & 37 & 15,4 & 21,6 & 51,4 & 27,0 \\
\hline FOSSA NEGRA & & & & & \\
\hline E OUTRO & 6 & 2,5 & 16,7 & 16,7 & 66,7 \\
\hline TOTAL & 240 & 100,0 & 15,8 & 35,4 & 48,8 \\
\hline
\end{tabular}

$X^{2}=8,99$, com 4 graus de liberdade, significativo a $10 \%$. 
A grande maioria das crianças $(82,1 \%)$ viviam em domicilios ligados à rede geral (pública) de esgoto. Para essa condição, verificou-se proporção de $14,7 \%$ de crianças com ZAK< -2 . Situação pior foi observada para as crianças com domicilio sem esgoto. $\mathrm{Na}$ amostra estudada, observou-se $21,6 \%$ de crianças com ZAl< -2 .

A pesquisa buscou avaliar a associação entre características da moradia, quanto ao aspecto "tipo de construção" e categoria do estado nutricional (TABELA 12)

TABELA 12. Número e percentagem de crianças segundo o tipo de moradia e categoria do estado nutricional. Americana, 1994.

\begin{tabular}{c|c|c|c|c|c}
\hline \multirow{2}{*}{$\begin{array}{c}\text { TIPO DE } \\
\text { MORADIA }\end{array}$} & \multicolumn{2}{|c|}{ CRIANÇAS } & \multicolumn{3}{c}{$\begin{array}{c}\text { CATEGORIAS DO ESTADO } \\
\text { NUTRICIONAL }\end{array}$} \\
\cline { 2 - 7 } & & & $\begin{array}{c}\text { ZAI }<-\mathbf{2} \\
\text { No }\end{array}$ & $\begin{array}{c}\mathbf{- 2} \leq \text { ZAI }<-\mathbf{1} \\
(\%)\end{array}$ & $\begin{array}{c}\text { ZAI } \geq-\mathbf{1} \\
(\%)\end{array}$ \\
\hline Alvenaria & 217 & 90,4 & 14,3 & 35,2 & 50,7 \\
Não alvenaria & 23 & 9,6 & 30,4 & 39,1 & 30,4 \\
\hline TOTAL & $\mathbf{2 4 0}$ & $\mathbf{1 0 0 , 0}$ & $\mathbf{1 5 , 8}$ & $\mathbf{3 5 , 4}$ & $\mathbf{4 8 , 8}$ \\
\hline
\end{tabular}

$X^{2}=5,27$, com 2 graus de liberdade, significativo a $10 \%$.

A maioria $(90,4 \%)$ das crianças vivem em moradias construídas em alvenaria. Note-se que a proporção de crianças com ZAI< -2 é muito maior entre as que moram em casas de "não alvenaria" $(30,4 \%)$ do que entre aquelas cuja casa é de alvenaria $(14,3 \%)$.

Tendo em vista as caracteristicas do saneamento básico (água tratada e esgoto) e de moradia em que vive a maioria das crianças estudadas, constata-se que o ambiente parece assegurar razoáveis condiçōes de saúde para as mesmas. 
Para avaliar a associação entre escore $Z$ de altura para idade e freqüência ou não à creche ou pré-escola elaborou-se a TABELA 13 , apresentada a seguir.

TABELA 13. Número e percentagem de crianças segundo a frequência à creche e pré-escola e categoria do estado nutricional. Americana, 1994.

\begin{tabular}{c|c|c|c|c|c}
\hline $\begin{array}{c}\text { FREQUÊNCIA A } \\
\text { CRECHE } \\
\text { OU }\end{array}$ & \multicolumn{2}{|c|}{ CRIANÇAS } & \multicolumn{3}{c}{$\begin{array}{c}\text { CATEGORIAS DO ESTADO } \\
\text { NUTRICIONAL }\end{array}$} \\
\cline { 2 - 6 } PRÉ-ESCOLA & No & $\%$ & $\begin{array}{c}\text { ZAI <-2 } \\
(\%)\end{array}$ & $\begin{array}{c}\mathbf{- 2} \leq \text { ZAI }<-1 \\
(\%)\end{array}$ & $\begin{array}{c}\text { ZAI } \geq \mathbf{- 1} \\
(\%)\end{array}$ \\
\hline SIM & 155 & 64,6 & 11,0 & 34,8 & 54,2 \\
NÃO & 85 & 35,4 & 24,7 & 36,5 & 38,8 \\
\hline TOTAL & $\mathbf{2 4 0}$ & $\mathbf{1 0 0 , 0}$ & $\mathbf{1 5 , 8}$ & $\mathbf{3 5 , 4}$ & $\mathbf{4 8 , 8}$ \\
\hline
\end{tabular}

$X^{2}=9,24$, com 2 graus de liberdade, significativo a $1 \%$.

É interessante destacar a substancial proporção $(64,6 \%)$ de crianças que durante a idade pré-escolar frequentaram creches. O fato da criança frequentar creche permite pressupor que há acesso à alimentação adequada, cuidados básicos e estimulação, o que contribuiria para a proteção contra a desnutrição. De acordo com os dados da TABELA 13 confirma-se a suposição. Note-se que a proporção de crianças com ZAl < -2 é substâncialmente menor $(11,0 \%)$ entre as que frequentaram creche. Para esse grupo a proporção com $\mathrm{ZAl} \geq-1$ é $54,2 \%$. A situação é desfavorável para as crianças que não frequentaram creche; neste caso $24,7 \%$ apresentam $Z A I<-2$ e $38,8 \%, Z A I \geq-1$.

Vale lembrar a importância que os primeiros dois anos de vida exercem sobre a altura da criança, por ser um período particularmente vulnerável. Neste sentido, estudo de MONTEIRO e col (1984) revelou que, em áreas de baixa renda do estado de São Paulo, 90\% do déficit estatural das crianças aos 7 anos já estava estabelecido aos 24 meses de idade. 
Após a constatação que o escore $Z$ de altura para idade e a freqüência à creche estão associados, julgou-se pertinente uma exploração mais detalhada envolvendo o controle da renda. Assim, busca-se conhecer, também, o risco relativo de desnutrição para as crianças que não freqüentaram creche conforme o estrato de renda familiar per capita a que pertencem (TABELA 14).

TABELA 14. Prevalência da desnutrição crônica entre escolares, conforme freqüência ou näo à creche e pré-escola, de acordo com dois estratos de renda per capita. Americana, 1994.

\begin{tabular}{|c|c|c|c|c|}
\hline $\begin{array}{c}\text { ESTRATOS DE } \\
\text { RENDA FAMILIAR } \\
\text { (Reais Per Capita) }\end{array}$ & $\begin{array}{c}\text { FREQÜÊNCIA À } \\
\text { CRECHE }\end{array}$ & $\begin{array}{l}\text { NÚMERO DE } \\
\text { CRIANÇAS }\end{array}$ & $\begin{array}{c}\text { PREVALÊNCIA DA } \\
\text { DESNUTRIÇÃO } \\
\text { CRÔNICA (ZAI <-2) } \\
(\%)\end{array}$ & $\begin{array}{c}\text { RISCO } \\
\text { RELATIVO }\end{array}$ \\
\hline \multirow[t]{2}{*}{$<50$} & SIM & 68 & 11,8 & 1,0 \\
\hline & NÃO & 64 & 28,1 & 2,4 \\
\hline \multirow[t]{2}{*}{$\geq 50$} & SIM & 87 & 10,3 & 1,0 \\
\hline & $\mathrm{NÄO}$ & 21 & 14,3 & 1,4 \\
\hline
\end{tabular}

$\bar{X}^{2}=5,29$, com 1 grau de liberdade, significativo a $5 \%$.

Os resultados apontam para a importância de acesso à creche, especialmente para as crianças mais pobres. Note-se que o risco relativo de desnutrição para os que não freqüentaram creche é substancialmente maior (praticametne o dobro) para crianças pertencentes a familias de menor renda.

Cabe citar estudo de SILVA \& STURION (1995) que analisando o estado nutricional de 2099 pré-escolares do municipio de Piracicaba, constataram, através de análise de regressão múltipla, a influência estatisticamente significativa (ao nivel de $1 \%$ ) exercida pelo tempo de permanência em creches sobre $o$ escore $Z$ de altura para idade das crianças, mesmo depois de controlado o efeito da renda. Periodos de permanência maior representaram maior adequação da altura/idade. Utilizando a mesma análise estatística, as autoras verificaram forte, e também significativa, influência (ao 
nivel de $5 \%$ ) do tempo de permanência na creche sobre o escore $Z$ de peso para a idade das crianças. Os resultados apontam para a importância que o atendimento infantil, operacionalizado através de creches, pode assumir como fator que contribui, de maneira positiva, para o crescimento das crianças.

Assim, dadas as características da faixa-etária de zero a 24 meses, é valioso dispor de programas de atendimento integral" e de qualidade, destinados à população infantil. Pode-se, também, conferir um potencial preventivo a essa modalidade de atendimento.

Tendo em vista que esta pesquisa mostrou que a freqüência ou não à creche pode ter importância na determinação do estado nutricional é recomendável que em estudos futuros essa variável seja pormenorizadamente caracterizada, coletando, por exemplo, informaçōes sobre idade de ingresso na creche, tempo de permanência e qualidade do atendimento.

Quando o objetivo é detectar a relação entre duas variáveis quantitativas, a análise de regressão ou correlação pode se mostrar mais eficaz qua a análise tabular. Note-se que na análise de regressão ou correlação não há necessidade de delimitar estratos para as variáveis, o que sempre envolve algum grau de arbitrariedade.

Fazendo regressão linear simples de ZAl contra o logarítimo do rendimento familiar per capita $(Y)$, obteve-se a equação:

$$
\mathrm{ZAI}=-2,17+0,325 \mathrm{Y}
$$

$O$ coeficiente de correlação entre ZAl e $Y$ é 0,206 , significativo ao nivel de $1 \%$. Confirma-se, portanto, o resultado obtido ao analisar a TABELA 6 , quando se constatou a forte relação entre ZAI e renda familiar per capita.

\footnotetext{
-Artigo 208, inciso VI, do capitulo VIII (Da Educaço, da Cutura e do Desporte), ao definir que o "dever do Estado com a educaça sera efelivado mediante garantia de (...) atendimento em creche e préscola ás crianças de zero a seis anos de idade"; e no artigo $7^{\circ}$, inciso XXV, do Capitulo II (Dos Direitos Sociais) quando inclui, entre outros direitos dos trabalhadores urbanos e ruarais, "assintencia gratuita aos filhos e dependentes desde o nascimento até seis anos de idade em creches e pré-escolas."
} 
Fazendo regressão linear simples de ZAl contra a escolaridade da mãe (EM, em anos), obteve-se:

$$
\mathrm{ZAI}=-1,20+0,0563 \mathrm{EM}
$$

O coeficiente de correlação entre ZAl e EM é 0,138 , estatísticamente diferente de zero ao nível de significância de $5 \%$. Cabe lembrar que ao analisar a relação entre ZAl e escolaridade da mãe através da análise tabular, distinguindo apenas dois niveis de ZAl, o qui-quadrado de tendência linear se mostrou significativo a $10 \%$ (ver página 46 ).

A técnica estatística de regressão múltipla permite analisar simultaneamente a influência dos diversos fatores considerados. Em uma regressão múltipla o coeficiente de uma variável explanatória mostra a sua influência sobre a variável dependente, já levando em consideração o efeito de todas as demais variáveis explanatórias incluídas no modelo.

É claro que uma variável pode mostrar um efeito significativo quando considerada isoladamente, mas não revelar efeito significativo quando for levada em consideração a influência de outras variáveis.

Verificou-se, através de regressão simples, que a escolaridade da mãe afeta o valor ZAI. Entretanto, quando é ajustada uma equação de regressão múltipla, incluíndo não apenas a escolariade da mãe, mas também o rendimento per capita, o tipo de abastecimento de água, a modalidade de esgoto, o tipo de casa (alvenaria ou não) e o fato da criança ter ou não frequentado creche ou pré-escola, então o efeito da escolaridade da mãe já não se revela estatisticamente significativo (Anexo III). Esse aspecto pode ser explicado, basicamente, pela colinearidade entre a escolaridade da mãe e rendimento familiar per capita; o fato de essas duas variáveis serem bastante correlacionadas torna dificil separar o efeito de cada uma delas sobre ZAI. O efeito do rendimento familiar per capita é mais forte, sendo estatisticamente significativo tanto na regressão simples quanto na múltipla.

Além do rendimento familiar per capita, a única outra variável explanatória que mostra influência estatísticamente significativa ao nivel de $5 \%$ 
sobre ZAl, na regressão múltipla, é a variável binária que indica se a criança frequentou ou não creche ou pré escola. $O$ fato de ter freqüentado creche ou pré-escola aumenta substancialmente (em 0,473 unidades)" o valor esperado de ZAl da criança, mesmo depois de considerado o efeito das demais variáveis explanatórias incluídas no modelo. Esse resultado merece destaque, pois comprova o papel preventivo que creches e pré-escolas podem exercer no sentido de evitar a desnutriçăo à medida que associam à educação o cuidado básico com saúde, alimentação e higiene. Possibilita, ainda, a entrada ou permanencia de mães no mercado de trabalho e, principalmente nas familias chefiadas por mulheres, libera o (a) irmão (ã) mais velho (a) - que na ausência do pai se sobrecarrega, seja com a entrada precoce no mercado de trabalho, ou atendendo em casa ao irmão menor - para frequentar a escola regular.

\subsection{CARACTERISTICAS DAS DIETAS}

Para avaliar o consumo alimentar diário dos escolares analisam-se, nesta seção, as caracteristicas, o valor e a qualidade nutricional das refeições.

Conforme descrito na metodologia, obteve-se o consumo alimentar dos escolares através do registro de alimentos correspondente a três dias alternados da semana, visando minimizar as possiveis diferenças que pudessem existir nos hábitos alimentares das crianças.

Deve-se destacar que o registro de alimentos consumidos nos CIEP's foi acompanhado de anotações sobre condimentos utilizados durante o preparo e também das quantidades adicionadas" pelas crianças durante as refeiçōes. Mesmo tendo recebido orientação prévia sobre a importância da precisão das informações sobre os alimentos consumidos fora da escola,

\footnotetext{
- Note-se que uma variaçăo de ZAl de quase 0,5 é substancial tendo em vista que, na distribuiçắo padrăo, o intervalo de -2 a 2 inclue $96,4 \%$ da distribuiça.

- Nas mesas dos refeitórios eståo disponlveis sal, vinagre, bleo e açúcar.
} 
grande número de crianças não declarou a quantidade de condimentos consumidos. Assim, optou-se por seguir os procedimentos adotados por LERNER (1994) visando as estimativas de quantidades de alguns condimentos quando os mesmos não foram registrados. De acordo com a autora, o óleo corresponde a $5 \%$ do peso dos alimentos consumidos, refogados ou assados, e o açúcar a $10 \%$ do peso dos alimentos fluidos.

É importante lembrar que a amostra inicial constituiu-se de 257 crianças pertencentes aos quatro CIEP's de Americana. Foi possivel obter informações do consumo alimentar de 244 crianças, que representa $94,9 \%$ do total amostrado.

Nos CIEP's, as atividades têm início às $7 \mathrm{~h}$ e $30 \mathrm{~min}$ com o fornecimento do desjejum. Diariamente são distribuídos, às crianças, leite integral, pão com margarina ou geléia de frutas. Alternadamente, em substituição ao pão, são oferecidos bolo ou biscoitos.

É interessante mencionar que a maioria $(91,4 \%)$ dos alunos amostrados recebem o desjejum nos CIEP's. Tal constatação diverge de MORGAN e col (1981) que relatam diversas investigaçōes sobre a omissão da refeição matinal ou à inadequação da mesma, acarretando tal comportamento dificuldades em adequar nutricionalmente as demais refeições do dia.

A segunda refeição do dia é o almoço, servido no período entre $11 \mathrm{~h}$ e $45 \mathrm{~min}$ e $12 \mathrm{~h}$ e $30 \mathrm{~min}$. Diariamente são fornecidos arroz e feijão, acompanhados de carne ou com substituição alternada de ovos, peixe ou embutidos. São frequentes também preparações como macarronada com molho à base de carne moída e polenta. Invariavelmente o prato principal é acompanhado por saladas e sobremesa. Na maioria dos dias foram servidas frutas após a refeição principal, durante o periodo de observação. Com menor freqüência são distribuídos doces, cremes ou gelatina.

A última refeição, nos CIEP's, é distribuida às $15 \mathrm{~h}$ e $30 \mathrm{~min}$. Em dois dias da semana é servida a sopa. No seu preparo são utilizadas, rotineiramente, carnes (principalmente a de frango) e hortaliças, acrescidas 
alternadamente de arroz, fubá, macarrão ou feijão. O horário, no entanto, parece pouco indicado para este tipo de prato, cuja tradição é serví-lo nas refeições principais.

Nos demais dias da semana, a última refeição (denominada de jantar pelos coordenadores do programa), consta alternadamente de lanches (acompanhados de suco ou leite) ou eventualmente doces.

Os alimentos consumidos fora do âmbito da escola apresentam razoável diversificação. Visando facilitar as análises, foram englobados na refeição denominada ceia.

Tendo como base as informaçōes obtidas, através dos formulários de registro de alimentos, elaborou-se a tabela de percentagem da presença de determinados alimentos, nas diferentes refeições do dia (desjejum, almoço e jantar) servidas nos CIEP's e do consumo de alimentos em nivel domiciliar e/ou em outros estabelecimentos (CEIA) - Tabela 15.

TABELA 15. Percentagem da presença de determinados alimentos nas refeições do dia. Americana, 1994.

\begin{tabular}{|c|c|c|c|c|}
\hline \multirow{3}{*}{ ALIMENTOS } & \multicolumn{4}{|c|}{ REFEIÇÃO } \\
\hline & \multicolumn{3}{|c|}{ CIEP'S } & DOMICILIARES \\
\hline & DESJEJUM* & ALMOÇO* & JANTAR $^{*}$ & CEIA** \\
\hline LEITE (inclui leite em pó e tipo $C$ ) & 83,6 & - & 24,0 & 7,6 \\
\hline QUEIJO & -. & $\ldots$ & - & 3,8 \\
\hline YOGURT & - & - & - & 1,1 \\
\hline PÃO & 63,8 & - & 19,3 & 35,0 \\
\hline MARGARINA & 61,1 & - & 4,3 & 2,5 \\
\hline AÇÚCAR & 53,6 & 6,3 & 27,4 & 7,3 \\
\hline CAFÉ (infusão) & 50,1 & - & 3,2 & 4,7 \\
\hline BISCOITO (doces e salgados) & 9,6 & - & 4,3 & 2,5 \\
\hline BOLO & 6,3 & 0,7 & 7,4 & 1,8 \\
\hline GELÉIA & 0,8 & - & - & - \\
\hline
\end{tabular}




\begin{tabular}{|c|c|c|c|c|}
\hline \multirow{3}{*}{ ALIMENTOS } & \multicolumn{4}{|c|}{ REFEIÇÃO } \\
\hline & \multicolumn{3}{|c|}{ CIEP'S } & \multirow{2}{*}{$\begin{array}{c}\text { DOMICILIARES } \\
\text { CEIA*** }\end{array}$} \\
\hline & DESJEJUM* & ALMOÇO* & JANTAR* & \\
\hline ARROZ & - & 85,7 & 22,9 & 21,3 \\
\hline FEIJĀO & - & 79,0 & 8,2 & 6,9 \\
\hline MACARRÃO & - & 16,7 & 21,7 & 2,1 \\
\hline FUBÁ & - & 5,7 & 6,5 & - \\
\hline BATATA & - & 21,7 & 13,9 & 3,8 \\
\hline MAIZENA & - & - & 7,3 & - \\
\hline PIZZA & - & -- & - & 2,5 \\
\hline PIPOCA & - & - & - & 0,8 \\
\hline \multicolumn{5}{|l|}{ CARNES } \\
\hline BOVINA ${ }^{\star \star \star *}$ & - & 24,6 & - & 3,1 \\
\hline AVES & -- & 41,3 & 13,9 & 5,8 \\
\hline PEIXE & - & 11,4 & - & - \\
\hline PORCO & - & 4,6 & - & -- \\
\hline OVOS & - & 14,2 & 3,2 & 15,1 \\
\hline \multicolumn{5}{|l|}{ EMBUTIDOS } \\
\hline SALSICHA & - & 9,0 & 5,3 & 4,9 \\
\hline LINGUIÇA & - & 1,9 & - & 6,0 \\
\hline MORTADELA & - & - & - & 11,1 \\
\hline PRESUNTO & - & - & - & 1,4 \\
\hline \multicolumn{5}{|l|}{ HORTALIÇAS (cozidas) } \\
\hline BROCOLI & - & 7,4 & - & - \\
\hline COUVE & - & 3,8 & 8,3 & 0,7 \\
\hline ESPINAFRE & - & 1,9 & - & - \\
\hline REPOLHO & - & 3,2 & 4,1 & - \\
\hline \multicolumn{5}{|l|}{ HORTALIÇAS (cruas) } \\
\hline ALFACE & - & 37,2 & - & 3,2 \\
\hline REPOLHO & - & 3,2 & 4,1 & - \\
\hline CHICÓRIA & - & 3,9 & 4,1 & - \\
\hline
\end{tabular}




\begin{tabular}{l|l|l|l|c}
\hline \multirow{2}{*}{ ALIMENTOS } & \multicolumn{4}{|c}{ REFEIÇÃO } \\
\cline { 2 - 5 } & \multicolumn{3}{|c|}{ CIEP'S } & DOMICILIARES \\
\cline { 2 - 5 } & DESJEJUM & ALMOÇO* & JANTAR $^{*}$ & CEIA** $^{*}$ \\
\hline
\end{tabular}

\section{LEGUMES (cozidos)}

CHUCHU

TOMATE

CENOURA

BETERRABA

PIMENTÃO

ABOBRINHA

$\begin{array}{lrrr}- & 4,7 & 2,0 & - \\ - & 30,1 & 8,3 & 3,1 \\ - & 11,8 & 4,0 & - \\ - & 3,1 & - & - \\ - & 0,6 & - & -\end{array}$

\section{LEGUMES (crus)}

TOMATE

PEPINO

ÓLEO DE SOJA

MAIONESE

$\begin{array}{rrrr}- & 7,8 & 4,8 & 0,6 \\ -- & 1,7 & - & -- \\ - & 80,1 & 20,0 & - \\ - & 3,4 & -- & 2,0\end{array}$

FRUTAS

LARANJA

BANANA

ABACATE

MELANCIA

MAMÃO

LIMĀO

ABACAXI

$\begin{array}{rrrr}- & 29,2 & 5,4 & 2,6 \\ - & 25,1 & 1,7 & 2,9 \\ - & 5,0 & 5,1 & 2,0 \\ -- & 4,9 & -- & - \\ - & 2,1 & - & - \\ - & - & 1,3 & - \\ - & -- & 1,4 & 1,0\end{array}$

PUDIM (chocolate e caramelo)

$\begin{array}{rrrr}- & 4,9 & 1,0 & - \\ - & 5,3 & 12,8 & - \\ - & - & - & 6,5 \\ - & - & - & 1,8\end{array}$

CHOCOLATE

CHÁ

REFRIGERANTE

SUCO DE FRUTAS (uva)

SORVETE

GARAPA

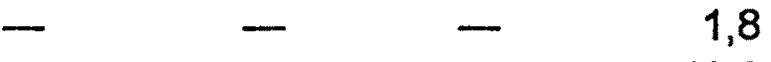

CHICLETES/BALAS/DROPS

- $\quad-\quad 13,3$

$\begin{array}{lllll}- & - & - & - & 1,7\end{array}$

$\begin{array}{lllll}- & - & - & - & -\end{array}$

* Refeiçóes dos CIEP's

* Refeiçoses domiciliares elou outros estabelecimentos

* inclui miúdos

Obs.: Os traços (-) significam que nāo foi observado o alimento na refeiçăo. 
De acordo com a Tabela 15 verifica-se que os produtos lácteos, representados quase que exclusivamente pelo leite, aparecem em $83,6 \%$ dos desjejuns e em menor proporção $(7,6 \%)$ nas ceias. Alimentos como o queijo e o yogurt são pouco frequentes, sendo mencionados somente nas refeições realizadas fora da escola.

Analisando-se a presença de carnes nas refeiçōes, chama a atenção o consumo de aves (especificamente o frango): $41,3 \%$ nos almoços, $13,9 \%$ nos jantares e $5,8 \%$ nas ceias. Os dados observados parecem ser concordantes com as evidências sobre a evolução do consumo de frango no Brasil: aumento anual de 2,3 kg per capita em 1970 para 16,0 kg em 1992, confirmando uma variação positiva ao longo do tempo e indicando a generalização de seu consumo e a consolidação de um novo hábito alimentar entre a população de diferentes niveis de renda.

Possivelmente a carne de frango destaca-se entre os demais tipos em função de fatores como: alta aceitabilidade entre a população e o preço do produto $(\mathrm{BACCH}, 1994)$ que, nas últimas três décadas, sofreu drástica redução (aproximadamente $70 \%$ de redução real). $O$ fator custo torna o produto bastante acessivel, tanto para a prefeitura municipal (responsável pelo financiamento do programa de alimentação escolar) como para significativa parcela das famílias de Americana. Segundo ARAÚJO (1990), entre 1963, nos EUA, a "proporção entre consumo de carne bovina e de aves era de 2,3:1; atualmente a relação é praticamente unitária". No Brasil, nos últimos 15 anos verificou-se a mudança substancial: de 4:1 para 1,1:1.

Por outro lado SILVA \& FABRINI (1994) ressaltam que, embora inconteste, a disposição de consumo não está condicionada exclusivamente à questão relativa a preços. De acordo com os autores a tendência de consumo deve ser atribuída também à influência do trabalho de marketing e à própria dinâmica diária da vida do consumidor das grandes cidades. 
Deve-se ressaltar também a vantagem do consumo de carne de aves, cuja proporção de gordura é menor do que a presente nas carnes vermelhas, quando não é consumida a pele.

$\dot{E}$ interessante ressaltar que a frequência das carnes de porco e peixe é observada exclusivamente nas refeições fornecidas nos CIEP's.

Com relação aos ovos, verifica-se que a presença é equilibrada entre almoços $(14,2 \%$ ) e ceia $(15,1 \%)$. Note-se que, de acordo com MONDINI \& MONTEIRO (1994), a participação relativa dos ovos no consumo calórico total da população da região sudeste apresentou crescimento de $1,1 \%$ na década de 60 para $1,6 \%$ na década de 80 . O aumento contínuo do consumo de ovos, leite e derivados está sendo detectado nos últimos 25 anos, revelando, assim, mudanças no padrão alimentar das populações urbanas das regiōes sudeste e também nordeste do País.

Com relação ao arroz, constata-se que o mesmo está presente em $85,7 \%$ e $22,9 \%$ dos almoços e jantares, respectivamente. Verifica-se também que o mesmo aparece em $21,3 \%$ das ceias.

É importante ressaltar que o feijão é a fonte mais importante de ferro da dieta da população brasileira.

UCHIMURA (1994), estudando anemia e desnutrição entre crianças ingressantes em escolas estaduais, constatou que o consumo mais frequente de feijão entre os escolares estudados diminuiu o risco da deficiência de ferro.

De acordo com a Tabela 15, observou-se que o feijão aparece em $79,0 \%$ do almoço. As proporçōes decrescem para $22,9 \%$ no jantar e a $6,9 \%$ nas refeições domiciliares.

Quanto ao pão, nota-se que aparece em $63,8 \%$ do desjejum e $35,0 \%$ nas citações da ceia. O percentual verificado nas ceias é superior ao consumo de arroz $(21,3 \%)$ e feijão $(6,9 \%)$ nas refeiçōes em nível domiciliar. Uma das explicações plausiveis para a maior presença do pão na última refeição do dia é o fato de tanto o arroz quanto o feijão exigirem maior tempo de cocção, o que dificulta o consumo em sociedades urbanizadas onde as mulheres participam 
cada vez mais do mercado e há tendência de reduzir o tempo dedicado ao trabalho doméstico.

Outras interpretaçōes para o fenômeno são apresentadas por HARVEY (1993) que destaca as modificações sociológicas subjacentes à passagem da modernidade à pós-modernidade. $O$ autor argumenta que a aceleração no tempo de giro de capital, a flexibilidade das práticas de trabalho, o avanço do conhecimento científico, administrativo burocrático e racional, vital para o progresso da produção e do consumo capitalista, traz consequências importantes principalmente para as práticas alimentares no meio urbano. Desse modo, o curto tempo que as pessoas têm para o ato de se alimentar transforma a pressa num dos traços visíveis da caracterização do modo de comer em regiões altamente urbanizadas, com o abreviamento do ritual alimentar em suas diferentes fases, da preparação ao consumo.

Estudo de HOFFMANN (1995) tece algumas consideraçōes sobre o declínio do consumo de feijão em áreas urbanas, ao longo do tempo. Segundo o autor, um dos condicionantes da queda poderia estar associado ao preço real em relação a outros produtos. No entanto, o autor demonstra, através da análise gráfica da série de preços (deflacionados pelo índice de preços de alimentos da Fundação Instituto de Pesquisas Econômicas da USP), que não houve tendência de crescimento real.

Deve-se ressaltar que LERNER (1994), estudando o consumo alimentar de jovens da regiäo metropolitana de São Paulo, verificou que os mesmos estão substituindo o jantar tradicional por lanches.

Ainda, de acordo com a Tabela 15, verifica-se que, entre os embutidos, se destaca a presença da salsicha no almoço $(9,0 \%)$ e no jantar $(4,9 \%)$. A mortadela aparece em $11,1 \%$ das ceias, sendo o embutido mais citado. Tal constatação reforça o argumento de que pode estar ocorrendo tendência de substituição da última refeição do dia por lanches que têm como base pão e mortadela. 
Quando se analisa a presença de hortaliças verifica-se que a maior proporção desses alimentos aparece em uma das refeições principais (almoço) oferecida nos CIEP's, destacando-se a alface e o tomate. A maioria dos legumes são habitualmente consumidos cozidos. Este fato pode contribuir para que ocorram perdas de ácido ascórbico durante a coç̧ão. Desse modo a preocupação com a preservação de nutrientes, dentre os quais o ácido ascórbico, deve ser constante nos serviços de alimentação. De acordo com SILVA (1990), a perda de ácido ascórbico pela manipulação desde a colheita até o seu consumo é exacerbado no serviço de alimentação uma vez que exige descongelamento, manutenção em temperatura elevada por longos intervalos de tempo.

Ressalta-se que as informaçōes obtidas nesta pesquisa são concordantes com os dados do ENDEF (1974/1975) que apontam para o tomate como o legume mais consumido pela população brasileira ( $78 \%$ das familias amostradas).

Estudos sobre consumo de alimentos, realizados em vários municípios do interior do estado de São Paulo, citados por MAZZILLI (1983) indicam o baixo consumo de hortaliças e frutas entre crianças.

WILSON e col (1980), estudando o consumo alimentar individual de crianças de 1 a 13 anos também encontraram baixa ingestão de hortaliças e frutas.

Resultados divulgados pelo Instituto de Nutrição Annes Dias do Rio de Janeiro (1985) destacam que $52 \%$ dos escolares recém ingressos na rede municipal de ensino não consumiam frutas e hortaliças.

Com relação à presença de frutas nas refeiçōes das crianças, verifica-se que laranja e banana destacam-se entre as demais, principalmente nas refeições fornecidas pelos CIEP's. Quando se analisa a presença de frutas nas refeiçōes domiciliares, constata-se proporção substancialmente menor (menos que $3,0 \%$ de citaçōes). 
Os dados do ENDEF (1974/1975) também apontaram para a laranja como sendo a fruta referida maior número de vezes $(74 \%$ das familias amostradas).

Recentemente LERNER (1994), estudando o consumo de hortaliças e frutas entre adolescentes, constatou baixa ingestão de ácido ascórbico.

Enfatiza-se que, de acordo com diversos autores (HALLBERG, 1981; HALLBERG e col, 1989 e HUNT e col, 1990), o ácido ascórbico constitui importante favorecedor do potencial de aproveitamento do ferro, principalmente do ferro não-heme. Trata-se, portanto, de elemento valioso, principalmente para o aproveitamento desse mineral da alimentação de populações, cuja dieta básica não dispõe de quantidades razoáveis de alimentos de origem animal. Segundo os referidos autores, cinquenta miligramas de ácido ascórbico, proveniente de frutas ou vegetais, são suficientes para duplicar a absorção do teor de ferro não-heme presente em uma mesma refeição.

É pertinente destacar a presença exclusiva do óleo de soja na maioria das refeições. A constatação é concordante com as análises elaboradas por MONDINI \& MONTEIRO (1994), tendo por base três inquéritos domiciliares, realizados ao longo dos últimos 25 anos. De acordo com os autores ocorreu importante alteração no consumo de gordura animal. Entre o primeiro (1962) e o terceiro inquéritos (1988), o consumo de manteiga caiu de $2,2 \%$ para $0,6 \%$ e o de margarina subiu de $0,4 \%$ para $2,5 \%$. Do primeiro para o terceiro inquérito, o consumo energético relativo à banha e toucinho decresceu de $4,9 \%$ para $1,0 \%$. No mesmo período, o consumo de óleo subiu de $7,7 \%$ para $13,5 \%$.

Embora importantes, são escassas, no País, informações sobre o consumo alimentar de crianças em idades escolar.

Tendo em vista o papel fundamental da alimentação na definição do estado de saúde das crianças e a importância do programa de alimentação para a viabilização da escola de tempo integral incluiu-se, entre os objetivos desta pesquisa, a análise do valor nutricional das refeições em nivel domiciliar e escolar, consumidas pelas crianças que frequentam os Centros Integrados de Educação Pública - CIEP's do Municipio de Americana. 
A adequação de energia e nutriente foi analisada tendo por base os valores de referência propostos por MARTINS \& HIDALGO (1983), conforme descrito na seção referente à metodologia.

\subsection{VALOR NUTRICIONAL}

Um dos objetivos deste estudo foi conhecer o valor nutricional das refeiçōes consumidas pelos escolares, tanto em âmbito dos CIEP's quanto em nivel doméstico.

A Tabela 16 apresenta o consumo médio diário de energia e nutrientes dos escolares de acordo com diversos estratos de idade.

TABELA 16. Consumo médio diário de energia e nutrientes dos escolares, segundo faixa etária. Americana, 1994.

\begin{tabular}{|c|c|c|c|c|c|c|c|c|c|c|c|}
\hline $\begin{array}{l}\text { FAIXA } \\
\text { ETARIA } \\
\text { (ANOS) }\end{array}$ & $\mathbf{N}^{*}$ & \% & $\begin{array}{c}\text { ENERGIA } \\
\text { (Kcal) }\end{array}$ & $\begin{array}{c}\text { PROTEI- } \\
\text { NA } \\
\text { (g) }\end{array}$ & $\begin{array}{l}\text { VIT. A } \\
\text { ( } \mu E R)\end{array}$ & $\begin{array}{c}\text { TIAMINA } \\
\text { (mg) }\end{array}$ & $\begin{array}{c}\text { RIBOFLA- } \\
\text { VINA } \\
\text { (mg) }\end{array}$ & $\begin{array}{c}\text { NIACINA } \\
\text { (mg) }\end{array}$ & $\begin{array}{c}\text { ÁCIDO } \\
\text { ASCÓR- } \\
\text { BICO } \\
(\mathrm{mg})\end{array}$ & $\begin{array}{c}\text { CÁLCIO } \\
(\mathrm{mg})\end{array}$ & $\begin{array}{c}\text { FERRo } \\
\text { (mg) }\end{array}$ \\
\hline$<8$ & 43 & 17,6 & $\begin{array}{r}1519 \\
(472)\end{array}$ & $\begin{array}{r}58,5 \\
(16,8)\end{array}$ & $\begin{array}{r}503,0 \\
(204,9)\end{array}$ & $\begin{array}{r}1.0 \\
(0,38)\end{array}$ & $\begin{array}{r}1,7 \\
(0,88)\end{array}$ & $\begin{array}{r}12,9 \\
(4,9)\end{array}$ & $\begin{array}{r}65,0 \\
(24,8)\end{array}$ & $\begin{array}{r}598,8 \\
(180,0)\end{array}$ & $\begin{array}{r}9,1 \\
(3,2)\end{array}$ \\
\hline $81-9$ & 39 & 16,0 & $\begin{array}{r}1635 \\
(437)\end{array}$ & $\begin{array}{r}61,2 \\
(16,4)\end{array}$ & $\begin{array}{r}674,2 \\
(281,1)\end{array}$ & $\begin{array}{r}1,0 \\
(0,4)\end{array}$ & $\begin{array}{r}1,6 \\
(0,8)\end{array}$ & $\begin{array}{l}13,0 \\
(5,1)\end{array}$ & $\begin{array}{r}67,7 \\
(27,4)\end{array}$ & $\begin{array}{r}609,5 \\
(194,1)\end{array}$ & $\begin{array}{l}10,1 \\
(3,3)\end{array}$ \\
\hline $9 \mid-10$ & 37 & 15,2 & $\begin{array}{r}1637 \\
(652)\end{array}$ & $\begin{array}{r}64,7 \\
(26,7)\end{array}$ & $\begin{array}{r}629,2 \\
(344,4)\end{array}$ & $\begin{array}{r}1,0 \\
(0,4)\end{array}$ & $\begin{array}{r}1,6 \\
(0,7)\end{array}$ & $\begin{array}{l}13,5 \\
(6,3)\end{array}$ & $\begin{array}{r}70,6 \\
(36,0)\end{array}$ & $\begin{array}{r}625,9 \\
(245,6)\end{array}$ & $\begin{array}{l}10,1 \\
(3,8)\end{array}$ \\
\hline $10 \mid-11$ & 35 & 14,3 & $\begin{array}{l}1790 \\
(772)\end{array}$ & $\begin{array}{r}72,2 \\
(32,5)\end{array}$ & $\begin{array}{r}789,9 \\
(449,1)\end{array}$ & $\begin{array}{r}1,2 \\
(0,6)\end{array}$ & $\begin{array}{r}1,9 \\
(1,2)\end{array}$ & $\begin{array}{r}15,8 \\
(9,4)\end{array}$ & $\begin{array}{r}77,7 \\
(38,3)\end{array}$ & $\begin{array}{r}703,5 \\
(252,9)\end{array}$ & $\begin{array}{l}11,3 \\
(5,3)\end{array}$ \\
\hline $11 \mid-12$ & 34 & 13,9 & $\begin{array}{r}1993 \\
(998)\end{array}$ & $\begin{array}{r}75,6 \\
(39,5)\end{array}$ & $\begin{array}{r}791,2 \\
(500,3)\end{array}$ & $\begin{array}{r}2,0 \\
(1,1)\end{array}$ & $\begin{array}{r}2,0 \\
(1,1)\end{array}$ & $\begin{array}{r}17,3 \\
(10,8)\end{array}$ & $\begin{array}{r}69,4 \\
(38,9)\end{array}$ & $\begin{array}{r}668,4 \\
(271,4)\end{array}$ & $\begin{array}{l}12,5 \\
(6,8)\end{array}$ \\
\hline $12 \mid-13$ & 31 & 12,7 & $\begin{array}{r}2110 \\
(1052)\end{array}$ & $\begin{array}{r}84,0 \\
(46,2)\end{array}$ & $\begin{array}{r}946,8 \\
(912,6)\end{array}$ & $\begin{array}{r}1,4 \\
(0,8)\end{array}$ & $\begin{array}{r}2,2 \\
(1,5)\end{array}$ & $\begin{array}{r}19,1 \\
(12,0)\end{array}$ & $\begin{array}{r}82,6 \\
(41,2)\end{array}$ & $\begin{array}{r}739,6 \\
(344,4)\end{array}$ & $\begin{array}{l}14,4 \\
(8,5)\end{array}$ \\
\hline$\geq 13$ & 25 & 10,3 & $\begin{array}{r}1921 \\
(737)\end{array}$ & $\begin{array}{r}75,7 \\
(30,9)\end{array}$ & $\begin{array}{r}793,0 \\
(582,3)\end{array}$ & $\begin{array}{r}1,3 \\
(0,5)\end{array}$ & $\begin{array}{r}1,8 \\
(1,0)\end{array}$ & $\begin{array}{r}17,0 \\
(8,2)\end{array}$ & $\begin{array}{r}83,6 \\
(56,5)\end{array}$ & $\begin{array}{r}618,4 \\
(236,2)\end{array}$ & $\begin{array}{r}12,3 \\
(5,7)\end{array}$ \\
\hline
\end{tabular}

* $N$ = número de crianças observadas

Obs.: Os números entre parênteses são os desvios-padrőes. 
O consumo médio de energia e proteína aumenta com a idade até doze anos, variando pouco nos intervalos entre 8 e 10 anos. Para as idades acima de treze anos verifica-se sensivel queda de consumo. Situação semelhante é observada com relação ao consumo médio de vitamina $A$.

De acordo com a Tabela 16 nota-se que os maiores consumos de vitamina $A$ e ácido ascórbico são verificados entre as crianças com onze e acima de doze anos, respectivamente.

Com relação ao cálcio pode-se observar que ocorre aumento no consumo até os dez anos. Nas idades subsequentes o consumo médio apresenta ligeira queda.

O consumo de ferro é menor entre as crianças com menos de 8 anos (9,1 mg). Ocorre elevação entre os dez e doze anos, voltando a diminuir entre as crianças com idade igual ou superior a treze anos (TABELA 16).

Para melhor visualizar a adequação global do consumo de calorias e nutrientes entre os escolares dos CIEP's, elaborou-se a TABELA 17.

TABELA 17. Distribuição dos escolares de acordo com a adequação do consumo médio diário de calorias e nutrientes e CIEP's estudados. Americana, 1994.

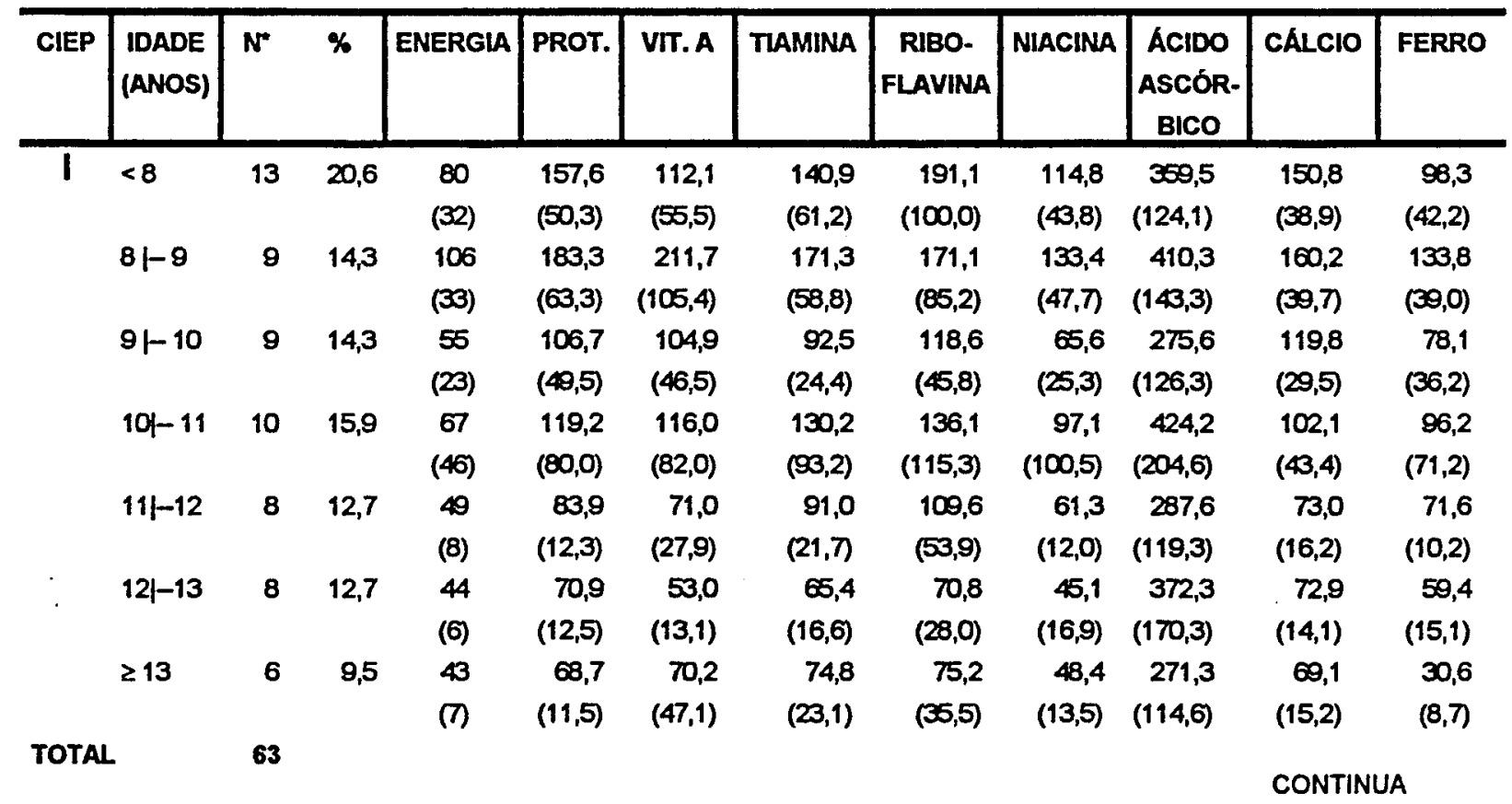




\begin{tabular}{|c|c|c|c|c|c|c|c|c|c|c|c|c|}
\hline CIEP & $\begin{array}{l}\text { IDADE } \\
\text { (ANOS) }\end{array}$ & $\mathbf{N}^{*}$ & $\%$ & ENERGIA & PROT. & VIT. A & TLAMINA & $\begin{array}{c}\text { RIBO- } \\
\text { FLAVINA }\end{array}$ & NIACINA & $\begin{array}{c}\text { ÁCIDO } \\
\text { ASCÓR- } \\
\text { BICO }\end{array}$ & CÁLCIO & FERRO \\
\hline \multirow[t]{14}{*}{ II } & \multirow[t]{2}{*}{$<8$} & \multirow[t]{2}{*}{9} & \multirow[t]{2}{*}{15,0} & 65 & 122,7 & 106,0 & 114,7 & 132,2 & 94,8 & 315,1 & 113,8 & 77,6 \\
\hline & & & & (9) & $(23,3)$ & $(29,7)$ & $(53,3)$ & $(\varpi, 3)$ & $(30,3)$ & $(143,1)$ & $(42,9)$ & $(21,0)$ \\
\hline & \multirow[t]{2}{*}{$8 \mid-9$} & \multirow[t]{2}{*}{9} & \multirow[t]{2}{*}{15,0} & 69 & 134,2 & 128,3 & 117,2 & 159,6 & 102,9 & 326,0 & 135,0 & 95,4 \\
\hline & & & & (16) & $(19,3)$ & $(32,2)$ & $(33,9)$ & $(87,1)$ & $(33,4)$ & $(138,0)$ & $(59,6)$ & $(27,4)$ \\
\hline & \multirow[t]{2}{*}{$9 \mid-10$} & \multirow[t]{2}{*}{9} & \multirow[t]{2}{*}{15,0} & 57 & 112,3 & 123,8 & 93,2 & 120,0 & 80,0 & 250,3 & 117,5 & 79,4 \\
\hline & & & & (8) & $(11,8)$ & $(51,0)$ & $(29,6)$ & $(54,8)$ & $(20,2)$ & $(85,2)$ & $(15,9)$ & $(18,5)$ \\
\hline & \multirow[t]{2}{*}{$10 \mid-11$} & \multirow[t]{2}{*}{8} & \multirow[t]{2}{*}{13,3} & 57 & 115,9 & 116,9 & 98,4 & 145,3 & 86,2 & 300,9 & 95,8 & 95,7 \\
\hline & & & & (7) & $(25,6)$ & $(38,5)$ & $(33,4)$ & $(\oplus, 5)$ & $(35,5)$ & $(132,5)$ & $(28,5)$ & $(26,2)$ \\
\hline & \multirow[t]{2}{*}{$|1|-12$} & \multirow[t]{2}{*}{9} & \multirow[t]{2}{*}{15,0} & 49 & 87,8 & 88,4 & 75,6 & 97,6 & 59,4 & 184,0 & 67,5 & 62,7 \\
\hline & & & & (8) & $(12,3)$ & $(30,3)$ & $(34,4)$ & $(75,8)$ & $(22,1)$ & $(91,3)$ & $(11,9)$ & $(18,7)$ \\
\hline & \multirow{2}{*}{$12\}-13$} & \multirow[t]{2}{*}{9} & \multirow[t]{2}{*}{15,0} & 54 & 96,9 & 96,2 & 108,0 & 106,5 & 66,9 & 244,9 & 79,2 & 95,1 \\
\hline & & & & (9) & $(27,8)$ & $(24,0)$ & $(53,0)$ & $(58,7)$ & $(23,1)$ & $(112,3)$ & $(17,6)$ & $(42,3)$ \\
\hline & \multirow[t]{2}{*}{$\geq 13$} & \multirow[t]{2}{*}{7} & \multirow[t]{2}{*}{11,8} & 55 & 96,9 & 60,1 & 90,9 & 96,2 & 70,7 & 130,4 & 75,7 & 45,0 \\
\hline & & & & (13) & $(16,2)$ & $(19,1)$ & $(38,7)$ & $(39,3)$ & $(13,8)$ & $(62,0)$ & $(14,4)$ & $(8,9)$ \\
\hline \multicolumn{2}{|c|}{ TOTAL. } & \multicolumn{2}{|l|}{60} & & & & & & & & & \\
\hline \multirow[t]{14}{*}{ III } & \multirow[t]{2}{*}{$<8$} & \multirow[t]{2}{*}{10} & 17,5 & 95 & 175,7 & 141,4 & 170,9 & 174,7 & 125,6 & 369,7 & 149,2 & 97,2 \\
\hline & & & & (25) & $(44,8)$ & $(63,4)$ & $(46,4)$ & $(94,0)$ & $(52,6)$ & $(131,9)$ & $(43,5)$ & $(34,7)$ \\
\hline & $81-9$ & 10 & 17,5 & 82 & 145,5 & 176,7 & 128,3 & 145,0 & 104,4 & 365,5 & 138,1 & 100,2 \\
\hline & & & & (13) & $(25,9)$ & $(69,8)$ & $(33,9)$ & $(64,8)$ & $(38,0)$ & $(107,2)$ & $(40,6)$ & $(24,1)$ \\
\hline & $9 \mid-10$ & 9 & 15,8 & 105 & 185,6 & 245,3 & 156,0 & 144,7 & 123,4 & 491,8 & 195,0 & 126,0 \\
\hline & & & & (33) & $(72,8)$ & $(105,7)$ & $(49,2)$ & $(48,5)$ & $(64,2)$ & $(240,5)$ & $(80,0)$ & $(46,6)$ \\
\hline & $10 \mathrm{~d}-11$ & 8 & 14,1 & 104 & 201,0 & 157,2 & 149,0 & 180,0 & 127,3 & 469,6 & 138,5 & 147,5 \\
\hline & & & & (29) & $(70,8)$ & $(75,8)$ & $(46,3)$ & $(95,4)$ & $(49,8)$ & $(247,5)$ & $(39,5)$ & $(52,0)$ \\
\hline & $111-12$ & 8 & 14,1 & 133 & 234,4 & 155,4 & 375,5 & 236,6 & 198,4 & 564,5 & 149,1 & 201,7 \\
\hline & & & & (36) & $(83,9)$ & $(88,3)$ & $(430,3)$ & $(65,7)$ & $(70,7)$ & $(234,8)$ & $(44,2)$ & $(61,8)$ \\
\hline & $12 \mid-13$ & 6 & 10,5 & 116 & 209,6 & 201,0 & 184,0 & 206,9 & 168,7 & 432,7 & 136,9 & 199,9 \\
\hline & & & & (21) & $(39,3)$ & $(36,8)$ & $(50,4)$ & $(91,7)$ & $(44,0)$ & $(140,3)$ & $(56,0)$ & $(39,1)$ \\
\hline & 213 & 6 & 10,5 & 95 & 164,1 & $1 \varpi 3,1$ & 132,1 & 156,0 & 135,2 & 264,6 & 108,2 & 84,4 \\
\hline & & & & (14) & $(18,1)$ & $(100,9)$ & $(18,4)$ & $(62,3)$ & $(20,0)$ & $(82,0)$ & $(28,9)$ & $(21,9)$ \\
\hline TOTA & & 57 & & & & & & & & & CONTII & \\
\hline
\end{tabular}




\begin{tabular}{|c|c|c|c|c|c|c|c|c|c|c|c|c|}
\hline CIEP & $\begin{array}{l}\text { IDADE } \\
\text { (ANOS) }\end{array}$ & $\mathbf{N}^{*}$ & $\%$ & ENERGIA & PROT. & VIr. A & TIAMINA & $\begin{array}{c}\text { RIBO- } \\
\text { FLAVINA }\end{array}$ & NIACINA & $\begin{array}{c}\text { ÁCIDO } \\
\text { ASCÓR- } \\
\text { BICO } \\
\end{array}$ & CÁLCIO & FERRO \\
\hline \multirow[t]{14}{*}{ IV } & $<8$ & 11 & 17,2 & 91 & 147,8 & 146,5 & 116,7 & 159,3 & 88,9 & 252,0 & 113,1 & 86,7 \\
\hline & & & & (20) & $(36,3)$ & $(39,6)$ & $(28,5)$ & $(89,8)$ & $(28,9)$ & $(67,7)$ & $(17,4)$ & $(21,8)$ \\
\hline & $81-9$ & 11 & 17,2 & 80 & 130,8 & 158,8 & 94,0 & 126,0 & 72,2 & 265,0 & 113,1 & 78,2 \\
\hline & & & & (11) & $(16,3)$ & $(36,9)$ & $(23,8)$ & $(56,1)$ & $(17,8)$ & $(134,4)$ & $(19,5)$ & $(13,2)$ \\
\hline & $9 \mid-10$ & 10 & 15,6 & 85 & 174,8 & 15,4 & 132,1 & 154,9 & 107,9 & 390,0 & 125,5 & 117,8 \\
\hline & & & & (15) & $(50,0)$ & $(62,3)$ & $(134,6)$ & $(70,0)$ & $(29,5)$ & $(139,8)$ & $(33,4)$ & $(24,2)$ \\
\hline & $109-11$ & 9 & 14,1 & 83 & 171,0 & 161,8 & 134,4 & 154,3 & 108,0 & 354,9 & 99,3 & 116,9 \\
\hline & & & & (21) & $(43,0)$ & $(100,0)$ & $(43,0)$ & $(88,1)$ & $(36,1)$ & $(151,5)$ & $(32,2)$ & $(39,9)$ \\
\hline & $11 \mid-12$ & 9 & 14,1 & 104 & 184,2 & 230,2 & 146,3 & 176,4 & 124,2 & 370,6 & 123,5 & 165,0 \\
\hline & & & & (13) & $(23,4)$ & $(75,4)$ & $(32,6)$ & $(53,4)$ & $(21,0)$ & $(65,2)$ & $(13,6)$ & $(20,6)$ \\
\hline & $|2|-13$ & 8 & 12,5 & 131 & 252,8 & 327,1 & 224,6 & 271,5 & 195,4 & 627,4 & 176,3 & 241,7 \\
\hline & & & & (29) & $(42,2)$ & $(233,3)$ & $(76,0)$ & $(115,1)$ & $(38,3)$ & $(186,6)$ & $(129,4)$ & $(54,2)$ \\
\hline & 213 & 6 & 9,3 & 102 & 183,2 & 152,3 & 160,8 & 168,6 & 140,7 & 473,1 & 130,7 & 85,2 \\
\hline & & & & (17) & $(37,8)$ & $(85,0)$ & $(53,4)$ & $(88,3)$ & $(48,5)$ & $(263,0)$ & $(44,3)$ & (23,9) \\
\hline TOTAL & & 64 & & & & & & & & & & \\
\hline
\end{tabular}

* $N=$ número de crianças observadas

Obs.: os números entre parênteses são os desvios-padrōes.

Analisando-se a adequação energética e protéica das dietas (consumo de alimentos nos CIEP's + consumo em nível domiciliar) observadas, verifica-se que a ingestão calórica constitui maior problema que a protéica entre as crianças da amostra.

Com relação à adequação energética das dietas dos escolares dos CIEP's I e II observa-se que, com exceção dos escolares de 8 anos de idade (CIEPI) que apresentam $106 \%$ de adequação, para os demais as proporções não ultrapassam a $80 \%$ das recomendações (Tabela 17).

A dieta do grupo de escolares dos CIEP's III e IV mostra situação razoavelmente satisfatória. Em ambas as unidades as crianças apresentam dietas que superam $80 \%$ de adequação calórica. É importante destacar que a 
situação é visivelmente melhor quando se observa as dietas das crianças com idades acima de onze anos.

Os resultados relativos à adequação energética são concordantes com aqueles obtidos por LERNER (1994). A autora estudou, também, o consumo alimentar de adolescentes, verificando que o mesmo difere de acordo com a localização da escola e que, invariavelmente, nas escolas situadas em bairros periféricos há maior porcentagem de adolescentes com dietas inadequadas.

No que diz respeito ao consumo protéico, os resultados apontam para adequação substancialmente superior a $100 \%$ das dietas dos escolares dos CIEP's III e IV. A mesma situação é observada com relação à adequação das dietas dos escolares dos CIEP's I e II, com idades até dez anos. Nas idades subsequentes a adequação varia de $68,7 \%$ a aproximadamente $97 \%$ (Tabela 17).

Deve-se notar que os dados são concordantes com o inquérito realizado pelo IBGE (1974/1975), o qual demonstrou que a problemática alimentar, em todas as regiões brasileiras, é de origem quantitativa, sendo a deficiência energética mais frequente do que a protéica.

Assim, o programa de alimentação desenvolvido nos CIEP's deverá levar em conta esse aspecto, estabelecendo, como meta, refeições que superem essa falha.

Buscou-se conhecer também a qualidade da dieta através da participação relativa de proteínas, lipídios e carboidratos na ingestão calórica total dos escolares.

A energia total da dieta está diretamente relacionada ao conteúdo de carboidratos, proteínas e gorduras.

Com relação à participação energética dos carboidratos, ressalta-se que os mesmos devem contribuir com valores em torno de $60-70 \%$ da energia total da dieta (SBAN, 1990). 
As proteínas devem contribuir com $8-10 \%$ do valor calórico total, sempre que as necessidades energéticas forem atendidas.

Quanto à ingestão de gorduras, note-se que estas constituem fonte concentrada de energia, extremamente útil para aumentar a densidade energética da dieta, especialmente nos grupos de escolares. Com base nessa propriedade e pelo conteúdo de ácidos graxos essenciais por elas veiculados, bem como por sua influência na absorção de nutrientes lipossolúveis, recomenda-se que as gorduras representem, $25 \%$ da energia total da dieta (SBAN, 1990).

Neste estudo os cálculos para avaliar a participação dos nutrientes descritos anteriormente tiveram por base os seguintes valores: $65 \%$ (carboidratos), 10\% (proteínas) e 25\% (lipídios).

O Gráfico 1 mostra a contribuição percentual de proteínas, lipídios e carboidratos para o total energético diário da alimentação dos escolares e o Gráfico 2 indica a participação relativa segundo as diferentes faixas de idade.

GRÁFICO 1. Porcentagem de proteinas, lipidios totais e carboidratos em relação ao valor energético total das dietas de escolares. Americana, 1994.

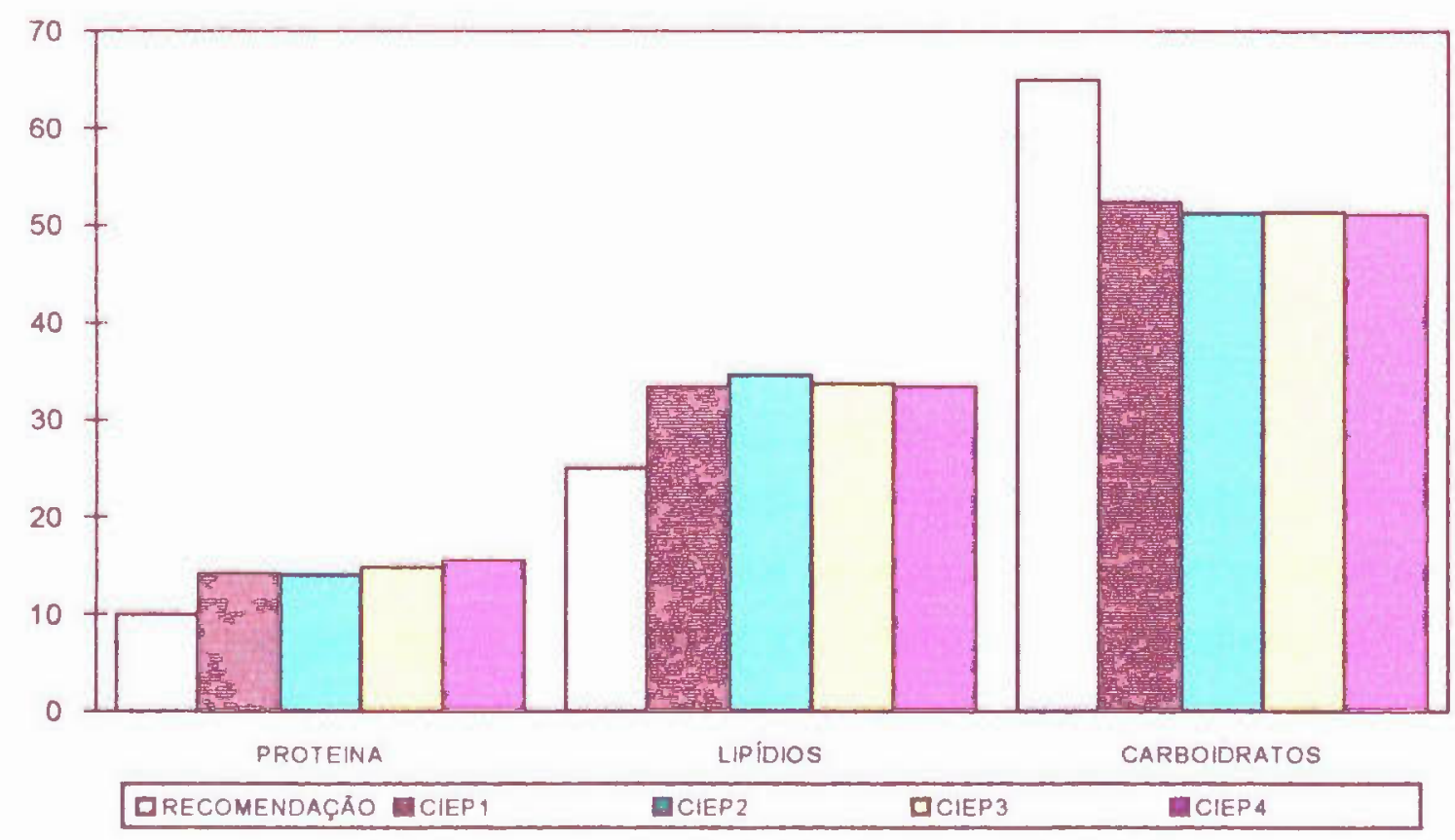


GRÁFICO 2. Porcentagem de proteinas, lipídios totais e carboidratos em relação ao valor energético total das dietas de escolares, segundo faixas de idade. Americana, 1994.

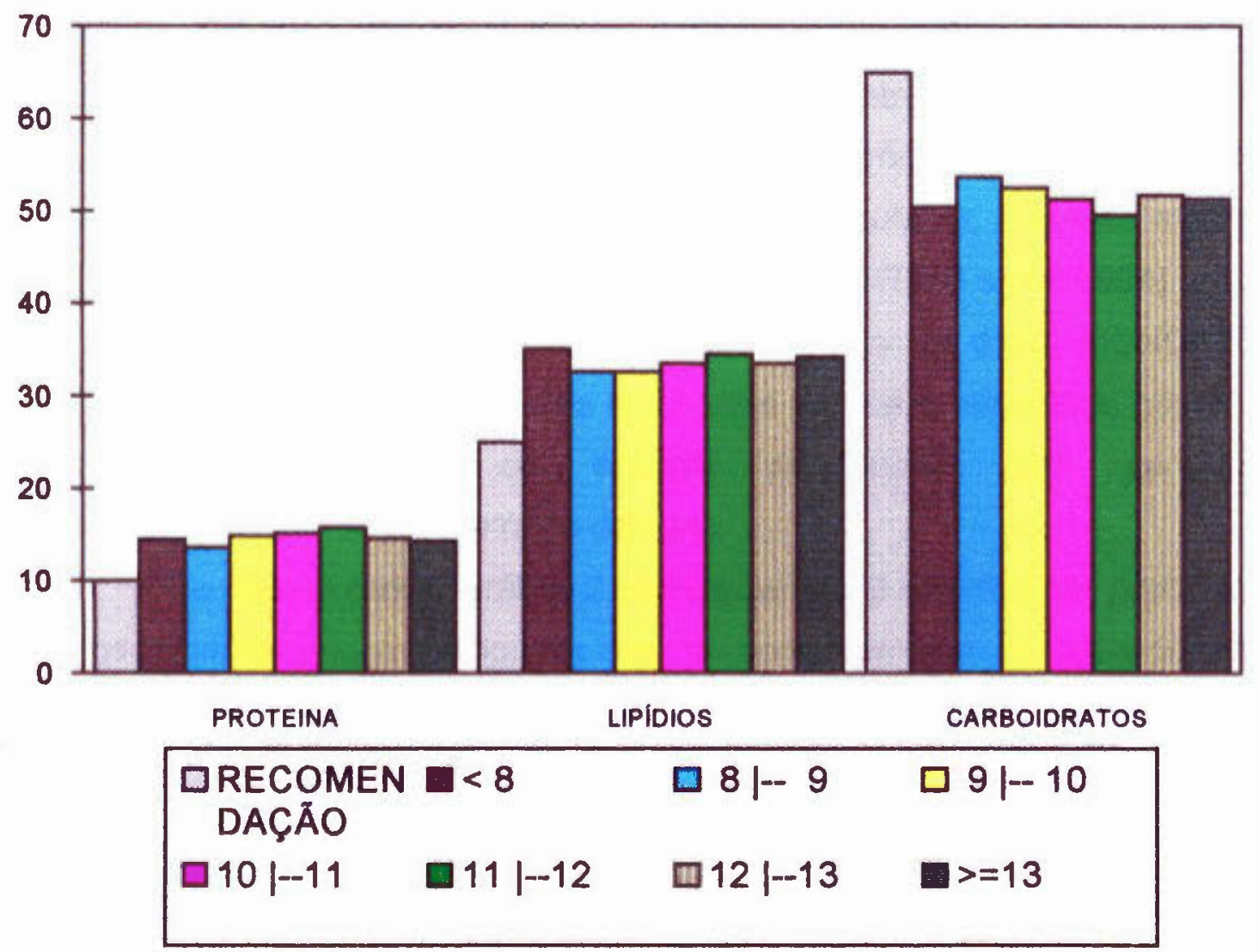

A análise da alimentação quanto à sua qualidade revela percentuais médios de proteínas e lipídios acima dos níveis recomendados.

Note-se que frente ao alto custo dos alimentos protéicos e, ainda, considerando que dietas com elevado teor de proteina exigem maior dispêndio energético do organismo (WILSON e col, 1979) torna-se anti-econômico privilegiar o atendimento às recomendações de caloria através de alimentos que representem boa fonte de proteína. Seria altamente recomendado maior presença de carboidratos, nutrientes principalmente energéticos, não só por 
acarretar menor gasto de calorias orgânicas, mas pela pronta liberação de energia e pela possibilidade de obtenção através de alimentos de mais baixo custo.

Embora a amostra tenha sido constituida por crianças menores de 14 anos, deve-se atentar para a participação calórica das gorduras. Experimentos e estudos observacionais têm demonstrado a estreita relação entre características qualitativas da dieta e ocorrência de enfermidades crônico-degenerativas, como as doenças cardiovasculares, diabetes mellitus (não insulino-dependente) e mesmo a obesidade (MARTINS e col, 1994).

Ainda, com respeito à composição lipídica da dieta, MONDINI \& MONTEIRO (1994) apontam para as evidências de que a obesidade possa se relacionar à proporçăo de energia proveniente das gorduras, independentemente do total calórico da dieta.

De acordo com o Gráfico 2 verifica-se que a contribuição percentual tanto de proteínas quanto de lipidios mostrou comportamento semelhante entre todas as faixas de idades: média de $14,7 \%$ para as proteinas e $33,8 \%$ para os lipídios.

No tocante à participação dos carboidratos, o consumo médio apresenta-se abaixo do recomendado. A observação está também de acordo com estudo longitudinal conduzido por RIGLEY \& HUNT (1995) entre 259 crianças de 8 a 11 anos pertencentes a diferentes grupos sociais. Os autores verificaram que a maioria dos escolares apresentaram consumo de carboidratos abaixo do recomendado.

Os resultados do presente estudo estão concordantes com as mudanças detectadas no padrão alimentar nos últimos 26 anos, tanto para as populações urbanas do sudeste quanto do nordeste do País.

De acordo com MONDINI \& MONTEIRO (1994), de forma geral as modificações observadas apontam para tendência generalizada de menor contribuição dos carboidratos no consumo calórico total e sua substituição por gordura. No gráfico 2 observa-se que a participação relativa de carboidratos na 
dieta dos escolares apresenta diferenças muito pequenas. Note-se que a ingestão média é de $51,6 \%$ e também não está correlacionada com os indicadores socio-econômicos e do estado nutricional.

Com relação à vitamina $\mathrm{A}$, as dietas dos escolares dos CIEP's III e IV são surpreendentemente adequadas, superando em muito as recomendações do nutriente para o grupo. A adequaçăo das dietas dos escolares dos CIEP's I e II apresenta nítido declínio a partir dos onze anos de idade (Tabela 17).

É surpreendente o nivel de adequação das dietas com relação ao ácido ascórbico. Em todos os CIEP's e faixas de idades estudadas verificou-se adequação muito superior a $100 \%$. Tal situação pode ser atribuída em parte à disponibilidade diária de hortaliças e frutas nas refeições oferecidas pelos CIEP's (Tabela 15). Nota-se a razoável frequência de citações à laranja.

Deve-se considerar, também, que o cálculo do valor nutricional baseia-se em tabela cujos dados se referem aos alimentos crus, não levando em conta as perdas acarretadas pela cocção. No caso das refeições servidas no âmbito das escolas esse fato pode ocorrer, considerando-se que as sopas, servidas aos escolares, são frequentemente preparadas à base de hortaliças e submetidas a processos de coç̧ão por tempo prolongado.

É importante ressaltar que o ácido ascórbico é considerado elemento de notória essencialidade no aproveitamento do ferro alimentar. A biodisponibilidade do ferro da dieta depende principalmente da presença de carnes e ácido ascórbico nas refeições. Tal situação é facilmente identificada na pauta alimentar das crianças, principalmente quando se analisa a frequência de citações dos referidos ítens nas refeiçōes oferecidas no âmbito dos CIEP's (TABELA 15).

De acordo com a Tabela 23 verifica-se que praticamente a totalidade das crianças dos CIEP's III e IV consomem dietas adequadas quanto ao conteưdo de tiamina, riboflavina e niacina. Exceção é observada quanto à 
adequação da tiamina na dieta dos escolares com 8 anos de idade e de niacina entre os escolares menores de 9 anos (CIEP IV).

Com relação às dietas das crianças do CIEP I verifica-se comportamento distinto. Maior percentual de adequação das vitaminas tiamina e riboflavina é observado nas dietas de escolares mais jovens (menores de 11 anos). Nas idades subsequentes a reduçāo é evidente, caindo praticamente para a metade quando comparada, com os primeiros intervalos de idade.

Ainda, de acordo com a Tabela 17, observa-se que em relação ao ferro as crianças com idade entre 8 e 12 anos do CIEP III apresentam dietas com níveis de adequação que ultrapassam as recomendações para o grupo. Situação mais privilegiada é observada entre as crianças com treze anos ou mais: as dietas atingem, em média $84,4 \%$ de adequação de ferro.

Ao analisar os CIEP's I e II, observa-se que os mesmos concentram escolares com dietas mais insatisfatórias quanto à adequação do ferro. Os menores percentuais são constatados entre as crianças mais velhas (treze anos ou mais) com $30,6 \%$ e $45,0 \%$ de adequação nos CIEP's I e II, respectivamente.

Ainda com relação ao ferro, verifica-se que nas unidades I e II há maiores percentuais $(19,1 \%$ e $11,7 \%$, respectivamente) de crianças com adequação abaixo de $50 \%$. Nos CIEP's III e IV a proporção de inadequados não atinge $20 \%$. Tal diferença persiste quando se analisa os percentuais de adequação entre 100-125\%. Nota-se que enquanto apenas $14,8 \%$ das crianças dos CIEP's I e II encontram-se nessa categoria, nos CIEP's III e IV observa-se $40 \%$.

Entretanto, quando se analisam as fontes dietéticas do ferro, é possivel observar razoável frequência do feijāo e carnes que são considerados importantes fontes do nutriente. No entanto, deve-se ressaltar que a presença do alimento é notada de forma mais sistemática nas refeiçōes oferecidas nos CIEP's. O mesmo nāo se pode afirmar quando se observa o percentual de citaçōes referentes aos alimentos presentes nas refeições consumidas em nível 
doméstico e/ou em outros estabelecimentos. Tais observações parecem concordar com dados obtidos por LERNER (1994) junto à população de adolescentes de Osasco, estado de São Paulo. A autora verificou que os jovens apresentaram tendência de mudança na prática alimentar, optando por substituir o jantar tradicional por lanches cuja composição nem sempre satisfaz os requisitos de uma alimentação adequada.

Desse modo, os escolares desperdiçam a oportunidade de incluir o feijão no jantar, considerado uma das mais importantes fontes de ferro na dieta da população brasileira.

Especificamente com relação ao estado de São Paulo, pesquisa realizada pelo IBGE (ENDEF, 1974/1975) mostrou que o feijāo é o produto que contribuiu com $17,3 \%$ do total de aminoácidos essenciais e nada menos do que $30,8 \%$ do consumo de ferro entre os paulistas em meados da década de 70 .

A ocorrência da menor frequência do consumo de feijão (em nivel doméstico) pode estar associada à urbanização o que levou maior número de mulheres para o mercado de trabalho. Tal comportamento invariavelmente contribui para que o tempo dedicado às atividades de preparo de alimentos seja reduzido. SENAUER e col (1986) demonstraram que, na área urbana do Sri Lanka, o crescimento do custo de oportunidade do trabalho doméstico das mulheres aumenta a demanda por pão, no caso, em detrimento da demanda do arroz, alimento até então considerado tradicional na dieta daquela população, como o feijão o é para os brasileiros.

Também, deve-se lembrar que a cocção do feijāo exige, além do tempo, despesas adicionais com o gás de cozinha havendo, portanto, custo monetário explícito.

Ao observar os dados referentes aos desvios-padrões, nota-se que houve grande variabilidade na adequação nutricional das dietas. As razōes dessa variação podem ser explicadas, em parte, pelo consumo de alimentos, bastante diverso entre as crianças. Note-se que a situação observada nessa pesquisa é similar aos resultados de estudos (SALAY \& CARVALHO, 1995; 
SILVA, 1991) envolvendo o consumo alimentar de escolares, desenvolvidos em municipios do interior paulista.

Em seguida analisa-se a relação entre a adequação do consumo e da renda familiar per capita dos escolares.

Os nutrientes cuja adequação se mostra estatisticamente associada ao logaritmo da renda per capita são energia $(r=0,114)$, proteina $(r=0,134)$, ferro $(r=0,211)$, riboflavina $(r=0,116)$, niacina $(r=0,182)$ e ácido ascórbico $(r=0,166)$. No caso da niacina, do ácido ascórbico e do ferro, a correlação da adequação com renda per capita é estatisticamente significativa ao nível de $5 \%$.

As respectivas equaçōes de regressão são apresentadas a seguir. Note-se que o logarítmo da renda per capita é indicado por $Y$. Os percentuais de adequação do consumo de energia, proteina, ferro, riboflavina, niacina e ácido ascórbico são representados, respectivamente, por: AENER, APROT, AFERR, ARIBO, ANIAC e AAASC. O valor do teste $t$ para a hipótese da nulidade do parâmetro é apresentado entre parênteses, abaixo do coeficiente, sendo assinalado com dois asteriscos se for significativo ao nível de $5 \%$ e com um asterisco se for significativo apenas ao nivel de $10 \%$.

$$
\begin{aligned}
& \text { AENER }=61,5+5,13 Y \\
& \left(5,35^{\circ}\right) \quad\left(1,73^{\circ}\right) \\
& \text { APROT }=104,9+11,24 Y \\
& \left(4,89^{\circ}\right) \quad\left(2,04^{-\prime}\right) \\
& \text { AFERR }=45,0+16,16 Y \\
& \left(2,33^{* \prime}\right) \quad\left(3,25^{* \prime}\right) \\
& \text { ARIBO }=100,6+13,28 Y \\
& \left(3,44^{*}\right) \quad\left(1,76^{*}\right) \\
& \text { ANIAC }=53,6+13,53 Y \\
& (2,84) \quad(2,79) \\
& \text { AAASC }=194,5+40,70 Y \\
& \left(3,12^{*}\right) \quad\left(2,53^{\prime \prime}\right)
\end{aligned}
$$

Embora nāo tenha sido objetivo deste estudo avaliar a prevalência de anemia e/ou deficiência de ferro entre os escolares, é pertinente ressaltar 
que os trabalhos de MOLINA (1989) e UCHIMURA (1994) apontam para o impacto da renda sobre a anemia.

De acordo com MOLINA (1989), crianças pertencentes a famílias pobres exibem tendência maior de risco (altamente significativo) para anemia do que aquelas de familias de melhor nivel socio-econômico.

UCHIMURA (1994), estudando escolares de Maringá, estado do Paraná, constatou que $84 \%$ dos anêmicos pertencem a familias com renda abaixo de um salário mínimo per capita. Observou, também, que mais da metade das crianças com renda per capita inferior a 0,50 salário mínimo são anêmicas.

Os escolares dos Centros Integrados de Educação Pública - CIEP's permanecem aproximadamente 10 horas em jornada de aulas $e$ atividades culturais e recreativas. Há, dessa forma, necessidade de se dispor de refeições que atendam significativa parcela das recomendaçōes nutricionais estabelecidas para o grupo.

Dada a importância que assumem refeições consumidas no âmbito dos CIEP's, elaborou-se a Tabela 18, onde se observa a contribuição percentual média do consumo de energia e nutrientes para 0 atendimento das recomendações para o grupo.

TABELA 18. Contribuição percentual média do consumo de energia e nutrientes de escolares no âmbito dos CIEP's. Americana, 1994.

\begin{tabular}{|c|c|c|c|c|c|c|c|c|c|c|c|}
\hline $\begin{array}{l}\text { IDADE } \\
\text { (ANOS) }\end{array}$ & $\mathbf{N}^{*}$ & $\%$ & ENERGIA & $\begin{array}{l}\text { PROTEI- } \\
\text { NA }\end{array}$ & VIT.A & TLAMINA & $\begin{array}{c}\text { RIBOFLA } \\
\text { VINA }\end{array}$ & NIACINA & $\begin{array}{l}\text { ACIDO } \\
\text { ASCÓR- } \\
\text { BiCO }\end{array}$ & CÁlCIO & FERRO \\
\hline$<8$ & 43 & 17,6 & $\begin{array}{r}65 \\
(17)\end{array}$ & & $\begin{array}{l}110,3 \\
(45,3)\end{array}$ & & $\begin{array}{l}137,2 \\
(80,0)\end{array}$ & $\begin{array}{r}82,1 \\
(32,6)\end{array}$ & $\begin{array}{l}272,2 \\
(89,8)\end{array}$ & $\begin{array}{l}105,1 \\
(24,9)\end{array}$ & $\begin{array}{r}72,0 \\
(26,8)\end{array}$ \\
\hline $81-9$ & 39 & 16,0 & $\begin{array}{r}68 \\
(20)\end{array}$ & $\begin{array}{l}122,6 \\
(34,9)\end{array}$ & $\begin{array}{l}151,6 \\
(66,3)\end{array}$ & $\begin{array}{r}99,0 \\
(37,6)\end{array}$ & $\begin{array}{l}128,0 \\
(\varpi, 3)\end{array}$ & $\begin{array}{r}84,5 \\
(37,8)\end{array}$ & $\begin{array}{r}285,1 \\
(124,3)\end{array}$ & $\begin{array}{l}100,5 \\
(27,0)\end{array}$ & $\begin{array}{r}82,2 \\
(31,1)\end{array}$ \\
\hline $9 \mid-10$ & 37 & 15,2 & $\begin{array}{r}50 \\
(20)\end{array}$ & $\begin{array}{l}117,1 \\
(42,6)\end{array}$ & $\begin{array}{l}139,4 \\
(82,1)\end{array}$ & $\begin{array}{r}83,5 \\
(32,1)\end{array}$ & $\begin{array}{l}114,2 \\
(53,2)\end{array}$ & $\begin{array}{r}75,9 \\
(29,4)\end{array}$ & $\begin{array}{r}300,3 \\
(132,8)\end{array}$ & $\begin{array}{l}110,7 \\
(33,0)\end{array}$ & $\begin{array}{r}81,1 \\
(27,6)\end{array}$ \\
\hline $10-11$ & 35 & 14,3 & $\begin{array}{r}62 \\
(24)\end{array}$ & $\begin{array}{l}122,8 \\
(52,0)\end{array}$ & $\begin{array}{l}120,4 \\
(76,7)\end{array}$ & $\begin{array}{r}\infty 9,3 \\
(39,5)\end{array}$ & $\begin{array}{l}125,3 \\
(72,1)\end{array}$ & $\begin{array}{r}83,6 \\
(43,2)\end{array}$ & $\begin{array}{r}334,9 \\
(174,6)\end{array}$ & $\begin{array}{r}88,0 \\
(24,3)\end{array}$ & $\begin{array}{r}90,3 \\
(38,1)\end{array}$ \\
\hline $11 \mid-12$ & 34 & 13,9 & $\begin{array}{r}57 \\
(31)\end{array}$ & $\begin{array}{l}122,1 \\
(63,8)\end{array}$ & $\begin{array}{l}118,3 \\
(88, \pi\end{array}$ & $\begin{array}{l}112,5 \\
(\sigma 2,0)\end{array}$ & $\begin{array}{l}133,1 \\
(74,3)\end{array}$ & $\begin{array}{r}92,5 \\
(54,2)\end{array}$ & $\begin{array}{l}308,0 \\
(154)\end{array}$ & $\begin{array}{r}84,8 \\
(29,2)\end{array}$ & $\begin{array}{l}104,7 \\
(56,7)\end{array}$ \\
\hline $12 \mid-13$ & 31 & 12,7 & $\begin{array}{r}64 \\
(33)\end{array}$ & $\begin{array}{l}121,2 \\
(69,0)\end{array}$ & $\begin{array}{r}151,0 \\
(143,1)\end{array}$ & $\begin{array}{l}115,7 \\
(72,8)\end{array}$ & $\begin{array}{r}134,7 \\
(102,2)\end{array}$ & $\begin{array}{r}94,3 \\
(6,3)\end{array}$ & $\begin{array}{r}300,6 \\
(182,9)\end{array}$ & $\begin{array}{r}87,1 \\
(39,7)\end{array}$ & $\begin{array}{l}118,0 \\
(74,1)\end{array}$ \\
\hline 213 & 25 & 10,3 & $\begin{array}{r}56 \\
\text { (21) }\end{array}$ & $\begin{array}{l}101,6 \\
(42,6)\end{array}$ & $\begin{array}{r}84,7 \\
(61,3)\end{array}$ & $\begin{array}{r}\infty, 2 \\
(39,5)\end{array}$ & $\begin{array}{r}101.2 \\
(59,1)\end{array}$ & $\begin{array}{r}76,0 \\
(39,1)\end{array}$ & $\begin{array}{r}227,2 \\
(125,6)\end{array}$ & $\begin{array}{r}72,3 \\
(21,7)\end{array}$ & $\begin{array}{r}47,3 \\
(24,8)\end{array}$ \\
\hline
\end{tabular}

"N = número de crianças observadas

Obs.: Os números entre parênteses săo os desvios-padrơes. 
Note-se que a contribuição média para o consumo calórico não alcançou $70 \%$ do recomendado. Os niveis mais baixos foram observados entre as crianças com nove anos (59\%) e com idade igual ou superior a 13 anos (56\%). Quando se observam os niveis de contribuiçăo alcançados pela proteína e demais nutrientes, nota-se que $o$ atendimento energético revela-se $o$ maior problema do consumo alimentar entre os escolares, principalmente os provenientes dos CIEP's I, II e IV. Tal fato reveste-se de importância, tendo em vista a fase de crescimento e desenvolvimento que caracteriza esses grupamentos etários.

Destaca-se que energia deve ser atendida com prioridade, e que proteínas sendo nutrientes energéticos poderão ser desviados de suas funções primordiais - síntese protéica para o fornecimento de calorias quando a dieta não fornece quantidades adequadas de hidratos de carbono e gorduras (OMS, 1985).

Ressalta-se, também, que vários autores (NUTTI, 1986; CESAR, 1990; SILVA, 1991 e SALAY \& CARVALHO, 1995) estudando programas de alimentação escolar, operacionalizados no estado de São Paulo, concluiram que a principal falha dos mesmos é fornecer refeiçöes de valor energético abaixo dos padrões propostos.

Quanto à proteína, deve-se notar a elevada adequação média do consumo entre as crianças de todos os estratos de idades estudados.

A situação observada pode ser atribuida, entre outros condicionantes, à tendência brasileira de aumentar e substituir o consumo de proteínas vegetais por proteínas animais, repetindo situação verificada, em décadas passadas, em diversos países desenvolvidos e mais recentemente em paises em desenvolvimento (MONDINI \& MONTEIRO, 1994).

Foram observados percentuais de adequação de tiamina e ácido ascórbico superiores a $100 \%$ entre as crianças de todos os estratos de idades analisados. 
Os resultados positivos quanto ao ácido ascórbico devem ser atribuídos à presença de frutas cítricas, servidas com frequência nas refeiçōes dos quatro CIEP's.

Quando se analisa o percentual de adequação das vitaminas $\mathrm{A}$ e tiamina constata-se que os mesmos podem ser considerados insatisfatórios somente para os escolares com treze anos ou mais.

Deve-se destacar que entre as vitaminas, a niacina apresentou pior nivel de adequação; o atendimento, através das refeiçōes dos CIEP's, não chegou a atingir $100 \%$ para nenhuma das faixas de idade estudadas.

É interessante ressaltar que SILVA (1991), estudando as refeiçōes distribuídas em escolas que mantinham jornada discente de 6 horas, constatou que entre as vitaminas, a niacina também foi o nutriente que apresentou o menor percentual de adequação.

O aumento do conteúdo de niacina nas refeições pode ser implementado com a inclusão, com maior frequêencia, do peixe, considerado fonte rica dessa vitamina. $O$ uso dos ovos nas preparaçōes também é um recurso a ser considerado, pois mesmo contendo pequenas quantidades de niacina, são considerados excelentes fontes de triptofano (precursor da niacina).

Analisando-se as refeições consumidas nos CIEP's, no que diz respeito aos minerais, observa-se que a adequação de cálcio è superior a $100 \%$ para crianças até 9 anos. 0 fato possivelmente decorre da presença do leite, boa fonte desse nutriente, que é servido diariamente em, pelo menos, uma refeição nos CIEP's.

Situação inversa é verificada em jovens acima de treze anos, o que talvez possa ser atribuida ao declínio do consumo de leite nesse grupo etário, havendo, inclusive, a tendência de abolir o alimento da pauta alimentar ou substitui-lo por refrigerantes e outras bebidas, principalmente nas refeiçōes consumidas fora do ambiente escolar. 
Com relação ao ferro, observou-se adequação abaixo de $50 \%$ entre as crianças acima de treze anos. Tal fato merece atenção, pois dados apresentados por FUJIMORI \& SZARFARC (1989) demonstram deficiência do nutriente principalmente entre jovens do sexo feminino durante a adolescência. As autoras encontraram proporção de $17,6 \%$ de adolescentes anêmicas, estando a ocorrência inversamente relacionada com variáveis indicativas do nível sócio-econômico.

No tocante às refeiçōes domiciliares, observou-se que proporção substancial $(13,7 \%)$ da amostra de escolares afirmou não consumir nenhum alimento. $\mathrm{O}$ impacto de tal comportamento é invariavelmente negativo, medida essa que pode predispor as crianças a déficits energéticos e nutricionais. Possivelmente, para esse grupo o Programa de Alimentação dos CIEP's constitui única fonte de alimentos do dia e, portanto, é pertinente que se corrija suas falhas visando o atendimento das recomendaçōes nutricionais diárias.

A seguir serāo apresentados os resultados relacionados à contribuição das refeiçōes consumidas em nivel domiciliar para atendimento das recomendações para o grupo.

TABELA 19. Contribuição percentual média do consumo de energia e nutrientes de escolares, em nível domiciliar. Americana, 1994.

\begin{tabular}{|c|c|c|c|c|c|c|c|c|c|c|c|}
\hline $\begin{array}{l}\text { IDADE. } \\
\text { (ANOS) }\end{array}$ & $\mathbf{N}^{*}$ & $\%$ & ENERCIA & $\begin{array}{c}\text { PROTEl- } \\
\text { NA }\end{array}$ & VITA & TLMINA & $\begin{array}{c}\text { RIBO- } \\
\text { FLAYINA }\end{array}$ & NIACINA & $\begin{array}{c}\text { ACIDO } \\
\text { Ascor- } \\
\text { BCO }\end{array}$ & CALCIO & FERRO \\
\hline$<8$ & 43 & 17,6 & $\begin{array}{r}19 \\
(18)\end{array}$ & $\begin{array}{r}33,8 \\
(31,6)\end{array}$ & $\begin{array}{r}16,1 \\
(27,8)\end{array}$ & $\begin{array}{r}33,3 \\
(30,8)\end{array}$ & $\begin{array}{r}29,7 \\
(32,9)\end{array}$ & $\begin{array}{r}23,9 \\
(25,2)\end{array}$ & $\begin{array}{r}52,9 \\
(78,6)\end{array}$ & $\begin{array}{r}28,0 \\
(26,2)\end{array}$ & $\begin{array}{r}18,8 \\
(16,7)\end{array}$ \\
\hline $8 \mid-9$ & 39 & 16,0 & $\begin{array}{r}16 \\
(13)\end{array}$ & $\begin{array}{r}24,9 \\
(18,7)\end{array}$ & $\begin{array}{r}17,0 \\
(23,2)\end{array}$ & $\begin{array}{r}26,9 \\
(24,7)\end{array}$ & $\begin{array}{r}21,0 \\
(20,9)\end{array}$ & $\begin{array}{r}16,8 \\
(15,3)\end{array}$ & $\begin{array}{r}52,8 \\
(92,7)\end{array}$ & $\begin{array}{r}25,6 \\
(32,8)\end{array}$ & $\begin{array}{r}18,4 \\
(15,0)\end{array}$ \\
\hline $9-10$ & 37 & 15,2 & $\begin{array}{r}17 \\
(13)\end{array}$ & $\begin{array}{r}28,5 \\
(24,8)\end{array}$ & $\begin{array}{r}17,9 \\
(28,3)\end{array}$ & $\begin{array}{r}25,4 \\
(24,0)\end{array}$ & $\begin{array}{r}20,9 \\
(17,7)\end{array}$ & $\begin{array}{r}18,8 \\
(22,0)\end{array}$ & $\begin{array}{r}52,6 \\
(105,5)\end{array}$ & $\begin{array}{r}28,4 \\
(30,8)\end{array}$ & $\begin{array}{r}19,7 \\
(17,2)\end{array}$ \\
\hline $10-11$ & 35 & 14,3 & $\begin{array}{r}16 \\
(12)\end{array}$ & $\begin{array}{r}27,6 \\
(22,4)\end{array}$ & $\begin{array}{r}17,9 \\
(26,1)\end{array}$ & $\begin{array}{r}29,1 \\
(30,1)\end{array}$ & $\begin{array}{r}27,7 \\
(35,1)\end{array}$ & $\begin{array}{r}20,7 \\
(25,3)\end{array}$ & $\begin{array}{r}53,7 \\
(80,7)\end{array}$ & $\begin{array}{r}20,2 \\
(17,4)\end{array}$ & $\begin{array}{r}22,9 \\
(22,0)\end{array}$ \\
\hline $11-12$ & 34 & 13,9 & $\begin{array}{r}16 \\
(12)\end{array}$ & $\begin{array}{r}24,8 \\
(17,2)\end{array}$ & $\begin{array}{r}19,3 \\
(33,9)\end{array}$ & $\begin{array}{r}23,4 \\
(21,8)\end{array}$ & $\begin{array}{r}21,0 \\
(18,9)\end{array}$ & $\begin{array}{r}17,2 \\
(18,4)\end{array}$ & $\begin{array}{r}41,0 \\
(74,5)\end{array}$ & $\begin{array}{r}18,0 \\
(18,4)\end{array}$ & $\begin{array}{r}20,0 \\
(17,2)\end{array}$ \\
\hline $12 \mid-13$ & 31 & 12,7 & $\begin{array}{r}19 \\
(14)\end{array}$ & $\begin{array}{r}30,8 \\
(24,4)\end{array}$ & $\begin{array}{r}13,7 \\
(22,9)\end{array}$ & $\begin{array}{r}26,0 \\
(18,8)\end{array}$ & $\begin{array}{r}24,6 \\
(20,9)\end{array}$ & $\begin{array}{r}19,8 \\
(15,6)\end{array}$ & $\begin{array}{r}73,3 \\
(121,2)\end{array}$ & $\begin{array}{r}26,7 \\
(27,6)\end{array}$ & $\begin{array}{r}25,9 \\
(18,3)\end{array}$ \\
\hline$>/ 13$ & 25 & 10,3 & $\begin{array}{r}17 \\
(12)\end{array}$ & $\begin{array}{r}25,4 \\
(17,0)\end{array}$ & $\begin{array}{r}24,7 \\
(42,4)\end{array}$ & $\begin{array}{r}25,0 \\
(18,9)\end{array}$ & $\begin{array}{r}21,7 \\
(18,1)\end{array}$ & $\begin{array}{r}21,6 \\
(16,7)\end{array}$ & $\begin{array}{r}51,5 \\
(148,0)\end{array}$ & $\begin{array}{r}22,8 \\
(21,4)\end{array}$ & $\begin{array}{r}13,3 \\
(9,0)\end{array}$ \\
\hline
\end{tabular}

* $N$ = número de crianças observadas

Obs.: os números entre parénteses săo os desvios-padröes. 
De acordo com a Tabela 19 verifica-se que a contribuição energética das refeiçōes domiciliares não apresenta grandes diferenças; os valores oscilam entre $16,0 \%$ (para idades de 8,10 e 11 anos) a 19\% (crianças com idades abaixo de 8 e com 12 anos).

É importante lembrar que de acordo com a Tabela 17, a dieta de parcela razoável de crianças, principalmente dos CIEP's I e II, não atendiam integralmente às recomendações para o grupo.

Ressalta-se que $49,2 \%$ e $25 \%$ dos escolares dos CIEP's I e II, respectivamente, apresentaram dietas que não alcançaram $50 \%$ de adequação energética. Destaca-se, porém, a ausência de escolares nos CIEP's III e IV nessa condição.

Situação bastante distinta é verificada para os niveis de adequação de proteina. Nas refeiçōes domiciliares a contribuição percentual é muito superior, reforçando, assim, a ingestão muito acima do preconizado.

Como já observado anteriormente, é mais comum a adequaçăo da dieta quanto ao conteúdo de proteínas.

Mesmo entre população de baixa renda, RIVERA \& RIVERA (1986) verificaram que o valor nutrícional da dieta consumida por escolares paraibanos, em relaçăo ao recomendado, representava, em média, $66,0 \%$ das calorias e $96,0 \%$ das proteinas. Os autores chamam a atenção para os aspectos de insuficiência e desequilibrio do consumo alimentar da população estudada.

Quanto às vitaminas, ressaltam-se os valores obtidos para o ácido ascórbico: enquanto 231 (94,7\%) dos escolares apresentam dietas com adequação em torno de $125 \%$, apenas $3(1,23 \%)$ com onze anos de idade, não atingiram $50 \%$ da recomendação. No entanto, ressalta-se que as refeiçōes dos CIEP's superam em mais de duas vezes as recomendaçōes para todas as faixas etárias.

Ainda, de acordo com a Tabela 19 , nota-se que a vitamina $A$ apresenta, em média, a menor adequaçăo. Tal situação possivelmente decorre 
da baixa frequência de alimentos considerados boas fontes desse nutriente nas refeições consumidas em nivel domiciliar (Tabela 15).

Note-se que o consumo de vitamina $A$ em casa é baixo, mas as refeições nos CIEP's contribuem com mais de $100 \%$ das recomendações, exceção apenas para o grupo etário de 13 anos ou mais (84,7\%). Somando-se $84,7 \%$ com $25,4 \%$, perfazem o total de $100 \%$, complementação essa que não se verifica em relação à energia.

Quanto ao cálcio, as refeições domiciliares revelam contribuição abaixo de $20 \%$ somente para os escolares de onze anos. Com relação ao ferro, constata-se que as refeições contribuem com $13,3 \%$ para as recomendações de crianças com idade igual ou superior a 13 anos, sendo o menor valor observado. Note-se também que para as demais idades o atendimento não ultrapassa a $25,9 \%$.

No entanto, deve-se ressaltar que a dieta de $66,8 \%$ dos escolares têm adequação de ferro superior a $75 \%$, entretanto entre eles, $43,6 \%$ alcançaram valores que são superiores a $125 \%$ de adequação.

Ressalta-se que justaposição dos dados apresentados nas Tabelas 18 e 19 mostra que o maior problema verificado diz respeito ao consumo deficiente em energia. Observa-se que os escolares mais velhos (13 anos ou mais) têm, em média, o pior nivel de atendimento das recomendações de energia. Tal fato aponta para a necessidade de dimensionar adequadamente a alimentação das crianças. Desse modo sugere-se a inclusão no cardápio dos CIEP's maior quantidade de alimentos que contribuam efetivamente para a elevação do teor energético das refeições.

Cabe mencionar, também, que tanto os escolares quanto seus familiares devem ser orientados no sentido de obter 0 atendimento das recomendações de energia, na medida do possível, através do consumo alimentar no domicílio. 


\subsection{QUALIDADE NUTRICIONAL DA DIETA}

Os estudos sobre às condiçōes alimentares em geral devem envolver a análise da qualidade da dieta e a adequaçăo de consumo, uma vez que a satisfação das necessidades nutricionais é determinada em funçăo do binômio qualidade/quantidade dos alimentos portadores de energia e nutrientes (MARTINS, 1982) De acordo com MARTINS (1982) a qualidade de uma dieta está vinculada à interação entre os nutrientes que a compōe.

Visando analisar a qualidade nutricional das dietas (consumo de alimentos nos CIEP's + consumo em nível domiciliar) aplicou-se o "Índice de Qualidade Nutricional (IQN) ${ }^{\circ}$ proposto por SORENSON \& HANSEN (1975). Este indice é calculado mediante equação que expressa a relação entre a densidade do nutriente - DN (quantidade ingerida do nutriente por 1000 kilocalorias) e as recomendaçōes nutricionais por 1000 kilocalorias. A relaçăo é individualizada por nutriente.

$O$ valor para energia é constante $(=1,0)$ porque, ao se calcular o IQN, pressupōe-se que as necessidades energéticas sejam atendidas, uma vez que esse indicador mede o potencial nutricional de dietas, refeiçöes ou alimentos, relacionado a um total energético pré-determinado, geraimente 1000 kilocalorias (MARTINS, 1982).

Qualquer nutriente da dieta que apresenta IQN igual ou superior a 1,0 estará adequado para satisfazer as necessidades de um determinado grupo, desde que sejam atendidos os requerimentos energéticos. Inversamente, IQN inferior a 1,0 indica inadequaçăo do nutriente analisado.

A adoção do IQN para a avaliação nutricional de dietas constitui-se em recurso valioso, pois trata-se de técnica simples, que revela, de imediato, a 
extensão das deficiências nutricionais e leva à orientação adequada, visando a correção de falhas constatadas na alimentação (HANSEN \& WYSE, 1980).

Nesta seção é apresentado inicialmente o IQN referente à dieta dos escolares em relação à cada um dos nutrientes observados (GRÁFICO 3). Em seguida, serão mostrados os valores de IQN referentes às três refeições consumidas pelas crianças, no âmbito dos CIEP's (Gráfico 4) e em nível domiciliar (Gráfico 5).

GRÁFICO 3. Índice de qualidade nutricional (IQN) das dietas dos escolares, de acordo com os CIEP's. Americana, 1994.

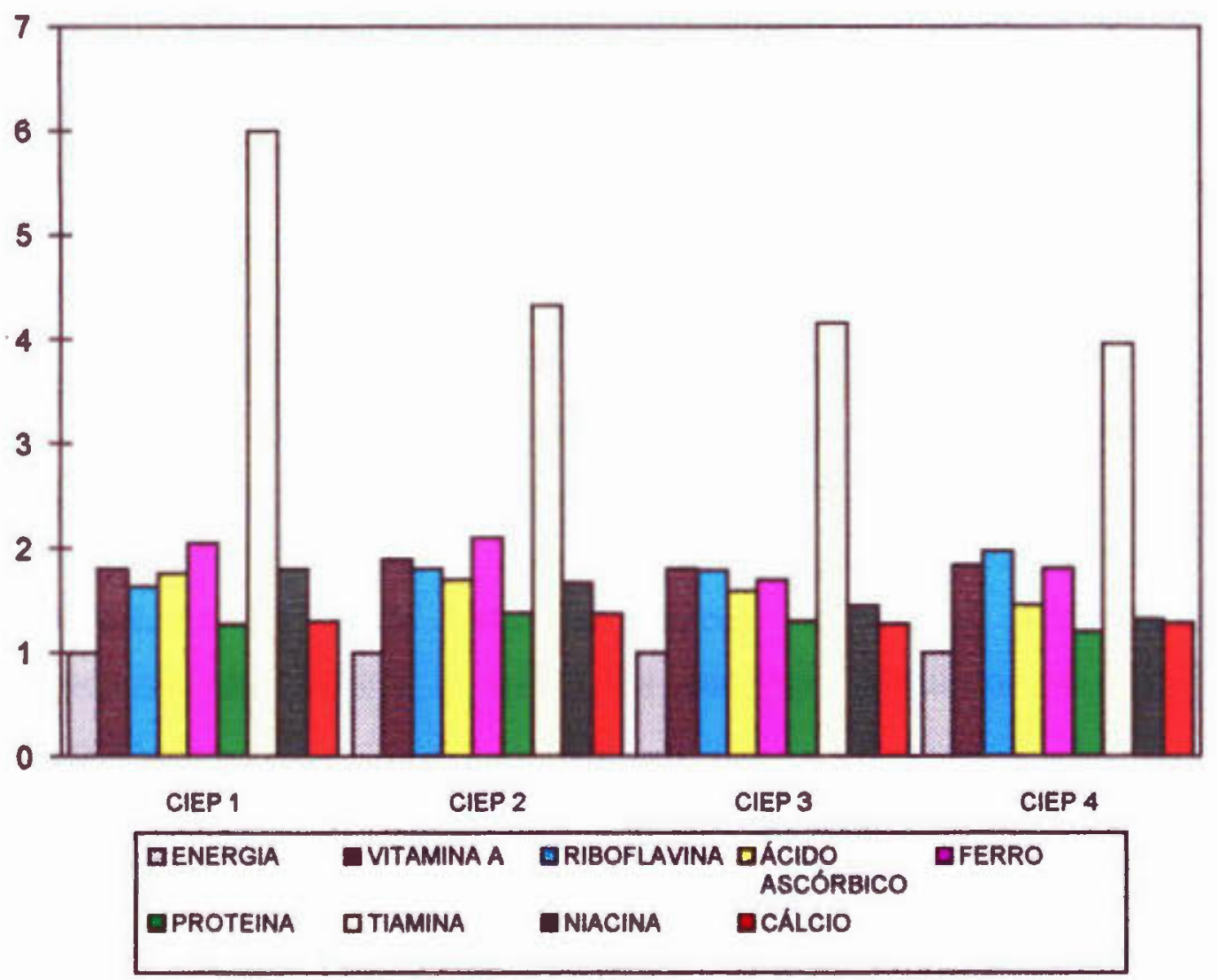

Note-se que os resultados estão expressos na forma de média (em relação ao número de alunos atendidos em cada CIEP e respectivas faixasetárias). 
Verifica-se que o valor do IQN da proteina das dietas é substancialmente superior a 1,0; enquanto os CIEP's I e III apresentam valores muito semelhantes, IQN em torno de 1,79, os CIEP's II e IV se diferenciam, ligeiramente, com dietas que apresentam IQN próximo a 1,90. Tal resultado indicaria que o conteúdo de proteina seria adequado, desde que fosse também suficiente o valor calórico. Contudo, como se ressaltou anteriormente, a dieta da maioria não alcançou $100 \%$ das recomendações de energia (TABELA 17). Desse modo, mesmo a dieta tendo apresentado conteúdo elevado de proteína, a quantidade de alimentos ingeridos pelos escolares apresenta-se insuficiente. De acordo com MARTINS \& HIDALGO (1983), sendo o valor calórico insuficiente, a proteína será, em parte, utilizada como fonte energética, comprometendo a sua participação na síntese orgânica.

Entre as vitaminas, nota-se que o IQN da niacina oscila de 1,20 (CIEP IV) a 1,37 (CIEP II), destacando-se como o mais baixo desse indicador de qualidade, mas ainda bem acima do considerado adequado $(1,0)$.

Ao se analisar o resultado referente à qualidade da dieta no que diz respeito ao ácido ascórbico verifica-se valor muito superior a 1,0 para a dieta de escolares do CIEP 1. A dieta nos demais CIEP's mostram-se muito semelhante, com IQN próximo de 4,0. Tal resultado deve ser visto com cuidado pois os cálculos têm como base alimentos crus. A maioria dos alimentos fornecedores de ácido ascórbico, exceto a laranja, são consumidos frequentemente cozidos, o que pode acarretar prejuizos no conteủdo do nutriente.

O IQN de cálcio das dietas foi elevado, variando de 1,31 (CIEP IV) a 1,79 (CIEP I). Tal situação decorre, provavelmente, da importante presença do leite, principalmente nas refeições oferecidas no âmbito da escola.

Ainda de acordo com o Gráfico 3, observa-se que o IQN do ferro é muito semelhante nas dietas dos escolares pertencentes aos CIEP's I, III e IV. Valor de IQN ligeiramente superior é notado nas dietas dos escolares do CIEP II. Embora o IQN situe-se acima de 1,0, as dietas das crianças de 
algumas faixas etárias revelaram-se deficientes em ferro, apontando para a necessidade de aumentar a oferta de alimentos fontes desse mineral nas refeições diárias desses escolares.

Os Gráficos 4 e 5 mostram os valores do IQN das refeições consumidas nos CIEP's em nivel domiciliar, respectivamente. Em ambas as situaçōes analisa-se a qualidade nutricional das refeiçōes, levando-se em consideração as faixas de idades dos escolares.

GRÁFICO 4. "Índice de Qualidade Nutricional” (IQN) das refeiçōes consumidas pelos escolares no âmbito dos CIEP's, segundo faixas de idade, Americana, 1994.

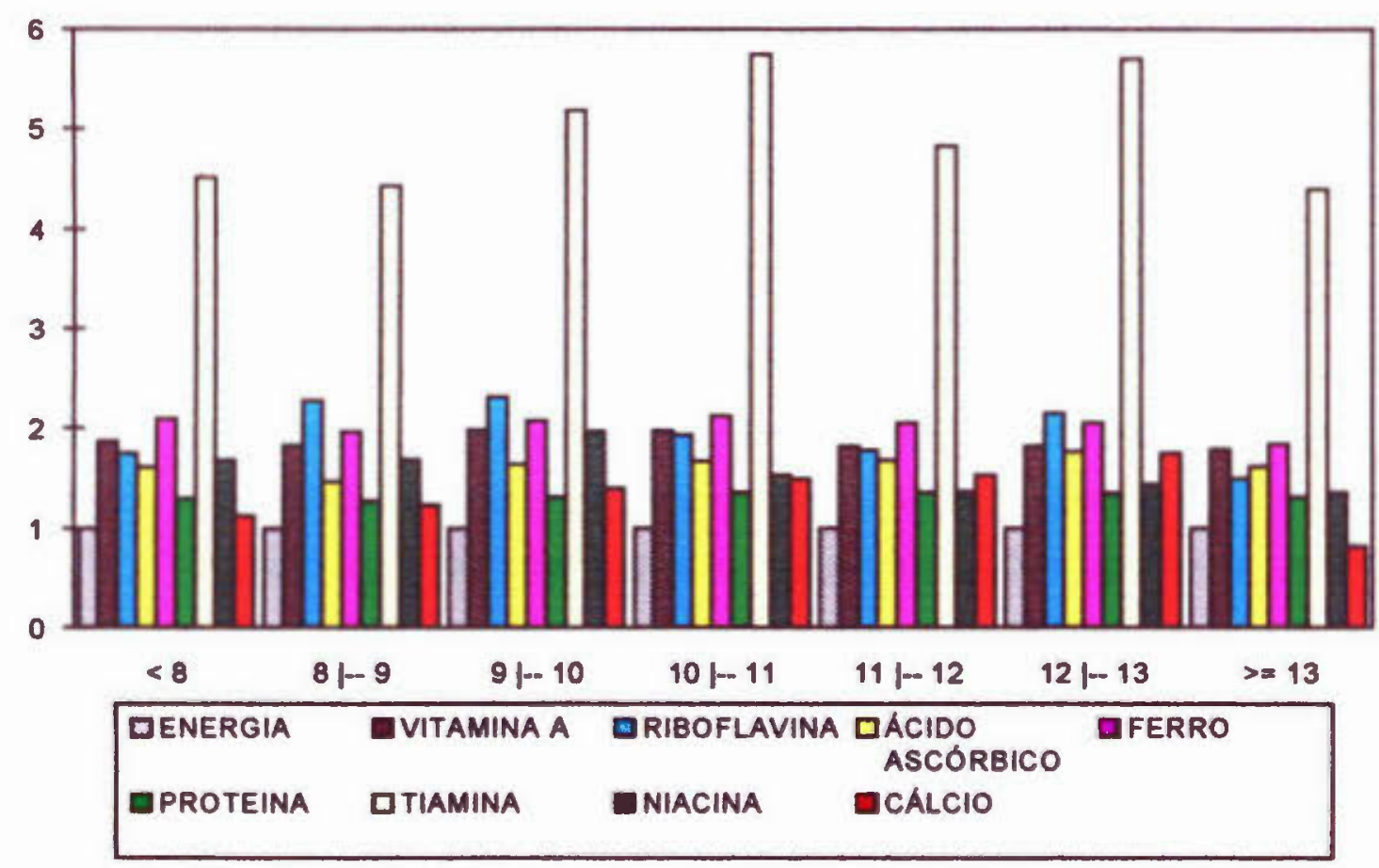


GRÁFICO 5. "Índice de Qualidade Nutricional” (IQN) das refeiçžes consumidas pelos escolares em nivel domiciliar, segundo faixas de idade. Americana, 1994.

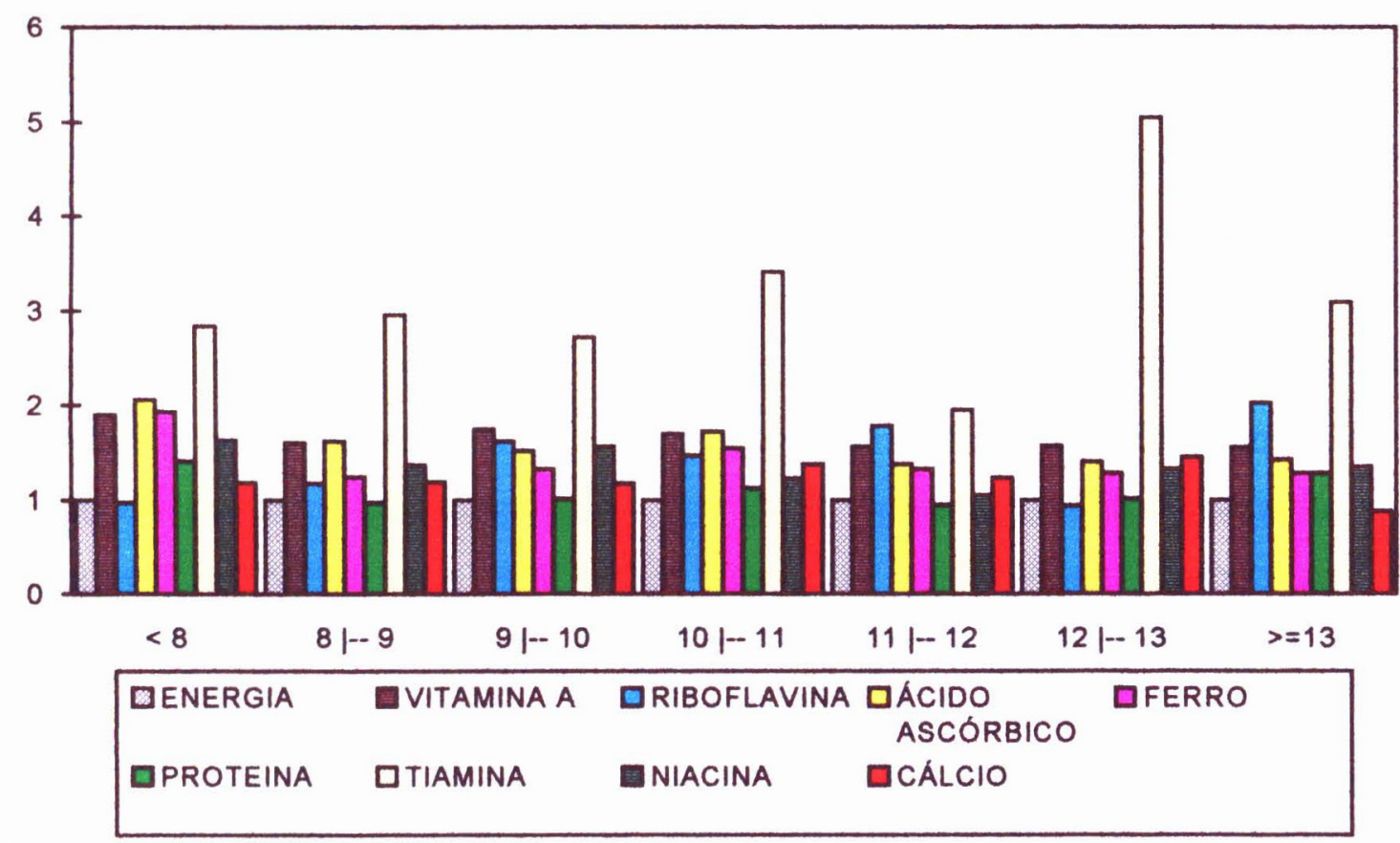

Ao analisar os gráficos 4 e 5 depreende-se que os valores de IQN da proteína superam o valor esperado $(1,0)$. Embora mesmo estando suficiente em proteína, a qualidade das refeições dos escolares está comprometida

Cumpre ressaltar que sendo o valor calórico insuficiente, a proteína será em parte utilizada como fonte energética (WILSON e col, 1979) e, portanto, torna-se anti-econômico atender às recomendações de calorias através de alimentos que representam boa fonte de proteinas.

Uma das maneiras de corrigir tal falha é incluir nas refeições dos escolares alimentos ricos em hidratos de carbono. Trata-se de nutriente energético com liberação de energia mais prontamente, contribuindo assim para a elevação do valor energético das dietas.

Quanto ao IQN relativo às vitaminas, nota-se que os maiores valores são verificados para o ácido ascórbico; sendo o menor valor observado $(1,99)$, nas refeições domiciliares muito superior ao esperado. 
Deve-se ressaltar que o conteúdo elevado de ácido ascórbico decorre da substancial quantidade de laranjas consumidas pelas crianças, como sobremesa, após a refeiçăo principal. Cumpre destacar que as hortaliças consideradas fontes de ácido ascórbico, embora presentes com razoável frequência nas refeições das crianças, na maioria das vezes, são preparadas sob forma cozida. Tal situação é constatada tanto nas refeições consumidas no âmbito da escola quanto no domicílio.

Nesse sentido, deve-se destacar estudo de SILVA (1990) que analisa o conteúdo de ácido ascórbico da dieta habitual do paulistano, mostrando que as perdas de ácido ascórbico variavam de 22 a $56 \%$ conforme o modo de preparo. Particularmente quanto ao tomate, a autora ressalta que independentemente dos tipos de preparo, verificou-se comportamento semelhante quanto à preservação do ácido ascórbico ( $66 \%$ na forma refogada; $74 \%$ na cozida por 5 minutos e $62 \%$ na cozida por 15 minutos).

É importante lembrar que de acordo com a Tabela 15, o tomate é o legume (preparado cozido) mais consumido pelos escolares, quando se considera o conjunto das quatro refeições do dia.

Observando-se o valor do IQN da vitamina A nota-se que, para todas as faixas de idade, foram obtidos valores superiores a 1,0 (três refeições consumidas nos CIEP's). Quando se analisa o IQN das refeições domiciliares, constata-se que os valores são ligeiramente inferiores a 1,0 para crianças menores de 8 anos e de doze anos de idade.

Entre as vitaminas, os resultados menos favoráveis foram obtidos para a niacina; os valores de IQN variaram de 0,95 (faixa de 11 a 12 anos) a 1,28 (idade acima de 13 anos). No entanto, nota-se que são valores muito próximos ao recomendado $(1,0)$

Ainda, com base nos Gráficos 3 e 4, verifica-se que o IQN do cálcio é superior a $1,0 \mathrm{em}$ todas as situaçōes analisadas, isto é, tanto quando considerada a modalidade da refeição (escola e domicílio) quanto as faixas de idade dos escolares. Tal situaçăo é atribuída principalmente à presença de 
alimentos fontes de cálcio nas refeiçōes consumidas nos CIEP's. Verifica-se diariamente a presença do leite, ótima fonte desse nutriente, no desjejum dos escolares. Como já destacado anteriormente, é apreciável a parcela de crianças que recebem essa refeição no âmbito do CIEP.

Quanto ao ferro, o valor do IQN é superior a 1,0 em ambas as modalidades de refeiçăo e para a maioria das faixas de idade. Exceção é verificada somente nas refeições consumidas pelas crianças mais velhas (13 anos ou mais); os valores do IQN (refeição das escolas e domiciliares) aproximam-se de 0,9. De acordo com LERNER (1994), trata-se de situação indesejável devido à influência direta do ferro na capacidade de trabalho, resistência à fadiga e aprendizagem das crianças pré-adolescentes.

Os resultados apontam para a necessidade de aumentar a oferta de alimentos, fontes desse mineral nas refeiçōes oferecidas aos escolares, contribuindo, assim, para evitar deficiências de ferro que possivelmente possam predispor o grupo de maior idade à anemia ferropriva. É desejável também manter os percentuais de atendimento do ácido ascórbico devido a sua valiosa contribuição para potencializar a absorção principalmente do ferro não-heme.

Enfatiza-se também a necessidade de orientar os escolares, sobretudo os de idades mais elevadas, no sentido de que não substituam alimentos, por exemplo, o feijão (fonte importante de ferro), principalmente na refeição consumida em nível domiciliar, por lanches cujo valor calórico e nutricional invariavelmente não atende às recomendações preconizadas para o grupo.

Ressalta-se que, nos adolescentes jovens (entre 10 e 14 anos), há um aumento muito rápido das secreções de diversos hormônios e o crescimento é acelerado, seguindo-se o aparecimento de caracters sexuais secundários (OMS, 1965). Desse modo, um bom estado nutricional é fator imprescindivel para atingir a maturação de forma adequada e para prevenir agravos físicos. 
Alguns atributos como força muscular, destreza, resistência permitem aos indivíduos participarem com maior êxito nas atividades de seu grupo reforçando sentimentos de auto-estima. 


\section{CONCLUSÕES}

- A prevalência da desnutrição crônica foi de $15,6 \%$, o que representa, aproximadamente, 6,8 vezes a proporção esperada;

- A maior $(26,6 \%)$ e a menor $(3,1 \%)$ porcentagens de desnutridos crônicos encontram-se nos CIEP's I e IV, respectivamente;

- A freqüencia à creche e/ou pré-escola e a renda per capita são os fatores que se associam estatisticamente ao escore $Z$ de altura para idade;

- O consumo alimentar (alimentos consumidos nos CIEP's e em nivel domiciliar) revelou-se deficiente em energia para $28,3 \%$ dos escolares, evidenciando o problema relativo à quantidade dos alimentos ingeridos;

- Entre os escolares, $68,9 \%$ apresentaram consumo protéico acima do preconizado para o grupo;

- Quanto ao teor de vitaminas, duas evidências importantes: a) o expressivo consumo de alimentos fontes de vitamina $C$ e b) a menor adequação em relação à niacina;

- A ingestão de energia, proteína, ferro, riboflavina, niacina e ácido ascórbico mostrou-se estatistiçamente associada à renda per capita;

- Observou-se expressiva contribuição das refeiçōes dos CIEP's em termos de proteína, vitamina $A$ e ácido ascórbico para as recomendações diárias desses nutrientes do grupo estudado; 
- A contribuição de ferro das refeiçōes dos CIEP's foi inferior a $85 \%$ das recomendações diárias para a maioria das faixas de idade dos escolares observados;

- Quanto ao cálcio, verificou-se contribuição acima de $70 \%$ para todas as faixas etárias, sendo que para as crianças mais jovens (até 9 anos) essa contribuiçăo supera $100 \%$;

- $O$ consumo energético em nível dos CIEP's revelou-se o maior problema. A contribuição das refeições escolares não ultrapassou $68 \%$. 


\section{REFERÊNCIAS BIBLIOGRÁFICAS}

AMIGO, $\mathrm{H}$. et al. Comparación de la situación nutricional en escolares de baixo nivel socioeconômico de Santiago (Chile) e São Paulo (Brasil). Arch. Latinoamer. Nutr. 45:31-35, 1995

ANJOS, L.A. et al. Indicadores de gordura corporal em crianças de 7 a 11 anos vivendo em condições sócio-ambientais diferentes no Rio de Janeiro, Brasil. Cienc. Cult., 41:1179-88, 1989.

ANJOS, L.A. Os desnutridos carregam o piano: quando a fome e o trabalho pesado perpetuam a miséria. Ciénc. Hoje, 17(100):115, 1993.

ARAÚJO, N. B. et al. Complexo Agroindustrial - o "Agribusiness" Brasileiro. São Paulo, Agroceres, 1990.

BACCHI, M.R.P. Previsão de preços de bovino, suino e frango com modelos de séries temporais. Piracicaba, 1994. [Tese de Doutoramento - Escola Superior de Agricultura "Luiz de Queiroz" da USP].

BAETA, A.M.B. et. al. O fracasso escolar: o estado do conhecimento sobre a evasăo e a repetência no ensino de $1^{\circ}$ grau no Brasil (1971-1981). Em aberto, 1(6): 1982.

BANCO MUNDIAL. World tables. Washington, D.C., 1992.

BARROS, A.A. et al. Evaluacion of the nutritional status of 1st year school children in Campinas, Brazil. Ann. Trop. Paediatr., 10:75-84, 1990. 
BASIOTIS, P. P. et al. Number of day of food intake records required to estimate individual and group nutrient intakes with defined confidence. $\mathrm{J}$. Nutr., 117: 1638-41, 1987.

BEATON,G.H. Small but healty? Are we asking the right question? Human Organ., 48:30-39, 1989.

BRUSCHINI, C. Estrutura familiar de trabalho na grande São Paulo. Cad. Pesq., 72: 39-57, 1990.

CESAR, A.T. O uso do ácido ascórbico no controle da deficiência de ferro utilizando a estrutura do Programa de Merenda Escolar. São Paulo, 1990 [Dissertação de Mestrado - Faculdade de Saúde Pública da USP].

COIMBRA, M. Cidade, cidadania e políticas públicas. In: Debates urbanos: qualidade da vida urbana. Rio de Janeiro, Zahar. Ed., 1982.

COLLARES, C.A.L. Influência da merenda escolar no rendimento em alfabetização: um estudo experimental. São Paulo, 1982 [Tese de Doutoramento - Escola Pós-Graduada em Ciências Sociais da Fundação Escola de Sociologia e Política de São Paulo].

COLLARES, C.A.L. \& MOISÉS, M.A.A. O renascimento da saúde escolar legitimando a ampliação do mercado de trabalho na escola. Cad Cedes: $O$ sucesso escolar: um desafio pedagógico. São Paulo, Cortez. 28, 1992.

Comissão Econômica para América Latina. A política social em tempo de crise articulação institucional e descentralizaçăo. Brasilia, 1990.

COSTA, M.A. Comparação das estimativas do custo/aluno em dois CIEP's e duas escolas convencionais do município do Rio de Janeiro. Educ. \& Soc. (40): 486-501, 1991. 
DALL'Acqua, F.M.O. Ajustamento econômico e as políticas sociais: o caso do programa de merenda escolar. In: Campino, A.C.C. \& Amaral, C.M., org. Questões sociais no Brasil. São Paulo, IPE/USP, 1994. 57-77.

FAO/OFICINA REGIONAL PARA AMÉRICA LATINA Y EL CARIBE. La nutricion: los lazos entre alimentacion, salud y desarollo. [Documentos preparados para la tele-conferência del dia mundial de la alimentacion, 16 de octubre de 1992].

FAO/OMS. Situacion alimentaria y nutricional de América Latina. Santiago, Chile, 1993.

FREIRE, W.B. \& BACALLAO, J. Primer censo nacional de los ninõs ecuatorianos de grado: aspectos metodológicos. Quito, Consejo Nacional de Desarrollo/Ministério de Educacion y Cultura, 1992.

FREITAS, L. A produção da ignorância na escola. São Paulo, Cortez, 1989.

FUJIMORI, E. \& SZARFARC, S.C. Prevaléncia de anemia e deficiência de ferro em mulheres adolescentes. In: Reunião Anual da Sociedade Brasileira para o Progresso da Ciência, 41 Fortaleza, 1989. Resumos [Ciência e Cultura, 41 (supl 7): 89, 1989].

FUNDAÇÃO IBGE. Tabela de composição de alimentos. Rio de Janeiro, 1977.

FUNDAÇÃO IBGE. Estudo nacional de despesas familiares: 1974/1975. Rio de Janeiro, 1978.

FUNDAÇĀO IBGE. Crianças e adolescentes: indicadores sociais. Rio de Janeiro, 1989. v. 1-3.

FUNDAÇÃO IBGE. Estatistica do registro civil: 1977 - 1989. Rio de Janeiro, 1991. 
FUNDAÇÃO IBGE. Censo demográfico; resultados do universo relativo às caracteristicas da população e dos domicilios. Rio de Janeiro, 1994.

FUNDAÇÃo SEADE. Movimento do registro civil. São Paulo, 1970-1989.

FUNDAÇÃo SEADE. Anuário estatístico do Estado de São Paulo. São Paulo, 1991.

FUNDAÇÃO SEADE. Perfil municipal (1980-1991). Região Administrativa de Campinas. São Paulo, 1993.

FURUMOTO, R.A. et al. Nutrição escolar: peso e altura de crianças de uma escola pública da periferia do Distrito Federal. In: Congresso Nacional da Sociedade Brasileira de Alimentação e Nutrição, 3. São Paulo, 1993. Anais. São Paulo, SBAN, 1993. p. 46.

GOLDING, J. Child health and the environment. B. Med. Bull., 42:204-11, 1986.

GRAITCER, P. L. \& GENTRY, M. Measuring children: one reference for all. Lancet, 2:297-9, 1981.

GUERI, M. \& DAZA, C.H. Situación alimentaria y nutricional en Latino America y el Caribe; Actualizacion 1991. Washington, D.C. Organización Panamericana de la Salud, 1991. (DOC HPN 91/1).

GUERRA, V.M.C.O. et al. Primeiro censo estadual de altura/idade dos escolares de $1^{\text {a }}$ série do ensino fundamental. Fortaleza, Secretaria da Educação do Estado do Ceará. Departamento de Assistência ao Estudante, 1993.

GUNTHRIE, H. \& CROCETTI, A. Variability of nutrient intake over a 3 - day period. J. Amer. Diet. Ass., 85:325-27, 1985. 
HABICHT, J. P. et al. Height and weight standars for pre-school children. How relevant are ethnic differences in growth potential? Lancet, 1:611-615, 1974.

HALBERG, L. Bioavailability of dietary iron in man. Ann. Rev., 1: 123-47, 1981.

HALBERG, L. et al. Iron absortion in man: ascorbic acid and dose-dependent inhibition by phytate. Am J. Clin. Nutr., 49:140-4, 1989.

HANSEN, R. G. \& WYSE, B. Expression of nutrient allowances us per 1000 kilocaries. J. Amer. Diet. Ass., 76: 223-7, 1980.

HARVEY, D. Condição pós-moderna. São Paulo, Loyola, 1989.

HOFFMANN, R. A diminuição do consumo de feijão no Brasil. In: Reunião do Consórcio das Instituições Brasileiras de Alimentação e Nutrição, 15\%. p. 6-15. São Paulo, 1995, Anais. São Paulo, CIBRAN, 1995.

HUNT, J. R. et al. Ascorbic acid: effect on ongoing iron absortion and status in iron depleted young women. Am J. Clin. Nutr., 51: 649-55, 1990.

INSTITUTO DE NUTRIÇĀO ANNES DIAS. Programa de Nutrição Escolar. Rio de Janeiro, 1985. mimeo.

INSTITUTO NACIONAL DE ALIMENTAÇĀO E NUTRIÇĀO (INAN). Programa nacional de alimentação e nutrição PRONAN II. Brasilia, 1976. (Documento Técnico, 06).

INSTITUTO NACIONAL DE ALIMENTAÇÃo E NUTRIÇÃo (INAN). Pesquisa nacional sobre saúde e nutriçáo; resultados preliminares. Brasilia, D.F., 1990. 
IUNES, R.F. \& MONTEIRO, C.A. Razões para a melhoria do estado nutricional das crianças brasileiras nas décadas de 70 e 80 . São Paulo, UNICEF/NUPENS/USP, 1993.

JOHNSON, V. Causes of hunger Food. Nutr. Bull., 3:1-9,1981.

KRALL, E. A. et al. Factors influencings accuracy of dietary recall. Nutr. Res., 8: 829-41, 1988.

L'ABBATE, S. Fome e desnutrição: os descaminhos da política social. São Paulo, 1982. [Dissertação de Mestrado - Faculdade de Filosofia, Letras e Ciências Humanas da USP].

LEI, D.L.M. Retardo do crescimento na idade pré-escolar: fatores sócioeconômicos, associação com o estado nutricional na idade escolar e prognóstico do aproveitamento discente no municipio de Osasco (área metropolitana de São Paulo). São Paulo, 1994. [Tese de Doutoramento Faculdade de Saúde Pública da USP].

LERNER, B.R. A alimentação e a anemia carencial em adolescentes. São Paulo, 1994 [Tese de Doutoramento - Faculdade de Saúde Pública da USP].

MACIAS, J.A. et al. Fundamentos de um sistema de vigilância alimentaria nutricional. Bol. Ofic. Sanit. Panam., 89:538-45, 1980.

MADDEN, J.P. et al. Validity of the 24-hs. recall: analysis of data obtained from elderly subjects. J. Am. Diet. Ass., 68:143-7, 1976.

MARTINS, I. S. Índice de qualidade do alimento: uma medida da qualidade e da adequação de dietas. Rev. Saúde Pública, 16:329-36; 1982.

MARTINS, I. S. et al. Hábitos alimentares aterogênicos de grupos populacionais em área metropolitana da região sudeste do Brasil. Rev. Saúde Pública, 28:349-56, 1994. 
MARTINS, I. S. \& HIDALGO, C. P. Recomendações nutricionais para a população brasileira. Brasília, INAN. 1983.

MASON, J.B. et al. Vigilancia nutricional. Ginebre, Organizacion Mundial de la Salud, 1964.

MAZZILLI, R. N. Contribuiçăo e interferência da merenda escolar no dia alimentar de crianças matriculadas em centros de educaçăo e alimentação do pré-escolar - CEAPE's. São Paulo, 1983 [Tese de Doutoramento Faculdade de Saúde Pública - Universidade de São Paulo].

MOLINA, M. C. B. et al. Nutritional status of children of urban low income comunities, Brasil (1986). Rev. Saúde Pública, 23:89-97, 1989.

MONDINI, L. Coleta e análise da altura de escolares ingressantes no primeiro grau como compenente de um sistema de vigilância nutricional: desenvolvimento de metodologia, implantação e avaliação. Rio de Janeiro, 1990. [Dissertação de Mestrado/Instituto de Nutrição/Universidade Federal do Rio de Janeiro].

MONDINI, L. \& MONTEIRO, C. A. Mudanças no padrão de alimentação da população urbana brasileira (1962-1988). Rev. Saúde Pública, 28:433-9, 1994.

MONTALI, L. Arranjos familiares: o esforço coletivo para viver na Grande São Paulo. Cad. Pesq., 72: 58-69, 1990.

MONTEIRO, C. A. \& BENÍCIO, M. H. D. Epidemiologia da desnutriçăo protéico-calórica. In: Nobrega, F. J. Desnutrição intra-uterina e pós natal. São Paulo, Panamed Ed., 1981. p. 120-9.

MONTEIRO, C. A. Critérios antropométricos no diagnóstico da desnutrição em programas de assistência à criança. Rev. Saúde Pública, 18:209-17, 1984. 
MONTEIRO, C. A. Coleta e análise da altura dos alunos ingressantes nas escolas de primeiro grau do País: uma proposta para um sistema nacional de acompanhamento do estado de saúde e nutrição da população. Pediatria, 65: 89-92, 1989.

MONTEIRO, C. A. et al. Saúde e nutrição das crianças brasileiras no final da década de 80. In: Fundação IBGE, Perfil estatístico de crianças e mães no Brasil. Aspectos de saúde e nutrição de crianças no Brasil: 1989. Rio de Janeiro, 1992.

MONTEIRO, C. A. et al. Nutritional status of brazilian children: trends from 1975 to 1989. Bull World Health Organ., 70: 657-66, 1993.

MORAES, M.A.C. Avaliaçāo dos efeitos da merenda escolar em alunos da $1^{2}$ série do $1^{9}$ grau na cidade de Paulinia - S.P. 1982. [Tese de Livre-Docente - Faculdade de Engenharia de Alimentos e Agricola da UNICAMP].

MORCILLO, A.M. Estudo comparativo de sete parâmetros antropométricos em escolares da cidade de Paulinia - São Paulo, referente aos períodos de 1979/1980 e 1984/1985. Campinas, 1987 [Tese de Doutoramento Faculdade de Ciências Médicas da Universidade Estadual de Campinas].

MORGAN, J. K; ZABIK, M. E.; LEVEILLE, G.A. The role of breakfast in nutrient intake of 5 to 12 years old children. Am. J. Clin. Nutr., 34: 14818-27, 1981.

MOYSES, M.A.A. Deficiência de ferro e desenvolvimento cognitivo: um estudo experimental em escolares. São Paulo, 1979. [Tese de Doutoramento Faculdade de Medicina - USP].

MUSGROVE, P. Do nutrition programs make a difference? The case of Brasil. Int. Health Serv, 20: 691-715, 1990.

NATIONAL CENTER FOR HEALTH STATISTCS. NCHS growth charts. Vital Health Stat., 25:1-22, 1976. 
NUTTI, M. R. Análise dos sistemas de alimentação escolar em 5 municípios do Estado de São Paulo. Campinas, 1986. [Dissertaçăo de Mestrado, Faculdade de Engenharia de Alimentos - UNICAMP].

ORGANIZACIÓN MUNDIAL DE LA SALUD. Problemas de la salud de la adolescencia. Ginebra, 1965. (OMS. Série de informes técnicos, 308).

PAN AMERICAN HEALTH ORGANIZATION. Health condition in the Americas. Washington, D.C., 1990. (PAHO Scientific Publication, $n^{\circ} 524$ ).

PARO, V.H. et al. Escola de tempo integral desafio para o ensino público. São Paulo, Ed. Cortez, 1988.

PATTO, M.H.S. A produção do fracasso escolar. histórias de submissão e rebeldia. São Paulo, T.A. Queiroz, 1990.

PEDRAZZANI, E.S. et al. Helmintoses intestinais II. Prevalência e correlação com renda, tamanho da família, anemia e estado nutricional. Rev. Saúde Pública, 22: 384-9, 1988.

PELIANO, A.M.M. Os programas de alimentação e nutrição para mães e crianças no Brasil. In: Monteiro, M.F.G. \& Cervini, R. orgs. Perfil estatistico de crianças e mães no Brasil. Rio de Janeiro, Fundação IBGE, 1992. p. 111-30.

PERSON, L. A. \& GARLGREN, G. Measuring children's diets: evaluation of dietary assessment techniques in infancy and childhool. Int. J. Epidemiol, 13:506-17., 1984.

PIPITONE, M.A.P. Programa de promoção integral da criança - PROFIC - da proposta teórica à implementação: o caso de Piracicaba, S.P. São Carlos, 1991. [Dissertação de Mestrado, Faculdade de Educação da Universidade Federal de São Carlos]. 
POLLITT, E. et al. Cognitive effects of iron deficiency anaemia. Lancet. 158, 1985.

POLLITT, E. Desnutricion y rendimento escolar. In: CUSMENSKY, M. et al. Crescimento y desarrollo. Washington, Organization Panamericana de la Salud, 1988. p. 324-48 (OPAS - publ. cientif., 510).

REUNIĀO CONSULTIVA CONJUNTA. FAO/OMS/UNU DE EXPERTOS EN NECESSIDADES DE ENERGIA Y PROTEINAS, Roma, 1981. Informe. Ginebra, Organizacion Mundial de la Salud, 1985. (OMS - série de Informes Técnicos, 724).

RIBEIRO, D. O livro dos CIEP's. Rio de Janeiro, Bloch Editores, 1986.

RIGLEY, L. \& HUNT, C. Dietary habits of 8 to 11 year old children - a longitudinal study. Food Sci. Tecnol. Today. 9:80-3, 1995.

RIVERA, F. et al. A desnutrição crônica por municípios, nos estudantes da primeira série do primeiro grau da $7^{\text {a }}$ Regiāo Educacional do Estado da Paraiba. Rev. Nutr. PUCCAMP, 7 (2): 113-31, 1994.

RIVERA, M. A. A. \& RIVERA, F. A. C. Perfil nutricional da dieta de escolares e pré-escolares pertencentes à população de baixa renda. CCS, 81:12-4, 1986.

SALAY, E. \& CARVALHO, J. F. Avaliaçăo do programa de merenda escolar do municipio de Campinas, Brasil. Arch. Latinoamer. Nutr., 45:167-71, 1995.

SENAUER, B. et al. The effect of the value of the time on food consumption patterns in developing countries: evidence from SRI LANKA. Am. Agricult. Econ., 68:920-7, 1986.

SESHADRI, S. et al. Behavioral reponses of young anaemic indian children to iron-folc acid supplements. Br. J. Nutr., 48: 233-40, 1982. 
SILVA, A.C. De Vargas a Itamar: politicas e programas de alimentação e nutrição. São Paulo, Instituto de Estudos Avançados/USP, 1994.

SILVA, L. F. \& FABRINI, L. C. Complexo avicola e questões sobre hábito alimentar. Cad. de Debate, 2:41-61, 1994.

SILVA, M. E. P. Teores de vitamina $\mathrm{C}$ em alimentos de consumo habitual na região de São Paulo. São Paulo. 1990. [Dissertação de Mestrado Faculdade de Ciências Farmacêuticas da USP].

SILVA, M. V. da. Contribuição do programa de merenda escolar - ciclo básico para as recomendações nutricionais de escolares da cidade de Piracicaba. São Paulo, 1991. [Dissertação de Mestrado - Faculdade de Saúde Pública/USP].

SILVA, M.V. \& PIPITONE, M.A.P. Curso de administração de programas de merenda escolar. Rev. Bras. Saúde Escolar, 3:183-8, 1994.

SILVA, M.V. \& STURION, G. L. Censo antropométrico das crianças dos centros educacionais e creches da Prefeitura Municipal de Piracicaba, Estado de São Paulo, $3^{\circ}$ Relatório Técnico. Piracicaba, ESALQ/USP, 1995.

SOARES, L.B.C.A. et al. Perfil Nutricional de escolares do CIEP "Dona Maria Portugal", Niterói. In: Congresso Nacional da Sociedade Brasileira de Alimentaçăo e Nutriçăo, $3^{0}$. São Paulo, 1993. Anais. Săo Paulo, SBAN, 1993.

SOCIEDADE BRASILEIRA DE ALIMENTAÇÃO E NUTRIÇÃO (SBAN). Aplicação das recomendaçōes nutricionais adaptadas à população brasileira. Cad. Nutr., (2) 1990.

SORENSON, A. W. \& HANSEN, R. G. Index of food quality. Nutr. Educ., 7:537, 1975. 
SPURR, G.B. Body Size, physical work capacity and productivity in hard work: is bigger better? In: Waterlow, J.C. Linear growth retardation in less develop countries. New York: Raven Press, 1988. p. 215-243. (Nestlé Nutrition Workshop Series, v.14).

TAYLOR, P. O aluno do futuro terá escolas com muitos serviços. Jornal do Brasil, Rio de Janeiro, 9 de maio de 1991.

TOMKINS, A. The risk of morbidity in a strinted child. In: Waterlow, J.C. Linear growth retardation in less develop countries. New York: Raven Press, 1988. p. 185-99. (Nestlé Nutrition Workshop Series, v. 14).

TONE, L.G. Valores hematimétricos, situação de transferrina e concentração de ácido fólico sérico de uma amostra de escolares do município de Pradópolis. Estado de São Paulo. Ribeirão Preto. 1983 [Tese de Doutoramento - Faculdade de Medicina da USP].

TURNER, J. M. Foetus into man. Physical growth from conception to maturiry. Massachusetts, Harvard University Press, 1978.

UCHIMURA, T.T. Anemia e desnutrição em escolares ingressantes nas escolas estaduais de Maringá, Pr. São Paulo, 1994. [Dissertação de Mestrado Faculdade de Saúde Pública da USP].

VALLA, V.V. A escola pública de $1^{\circ}$ grau é um serviço público - por 8 séries em 8 anos. IN: Cad. Cedes. 28, 1992.

VALVERDE, V. et al. The school as a data source for food and nutrition survelhance systems in Central America and Panamá. Food Nutr. Bull., 7 (4): 32-7, 1985.

WATERLOW, J. C. et. al. The presentation and use of height and weight data for comparing the nutricional status of groups of children under the age of 10 years. Bull. World Health. Organ., 55:489-98, 1977. 
WATERLOW, J.C. Reflections on stunting. Int. child. Health, 2(2):25-35, 1991.

WEBB, T.E. \& OSKI, F.A. Iron deficiency anemia and scholastic achievement in young adolescentes. J. Pediatr., 82: 827-30, 1973.

WILSON, D. et a. Nutrition status of children, inmates of a small institution of homeless children, in the Capital of the State of São Paulo, Brazil. Rev. Saúde Pública, (14): 300-9, 1980.

WILSON, E. D. et al. Principles of nutrition 4th ed. New York, Wiley, 1979.

WHO, Working Group. Use and interpretation of anthropometric indication of nutricional status. Bull. World Healt Organ., 64:929-41, 1986. 
ANEXOS 


\section{I - CONSUMO DE ALIMENTOS DO ESCOLAR}

NOME:

DATA DE NASCIMENTO:

CIEP:

SEXO: DATA DA AVALIAÇĀO:

\begin{tabular}{|c|c|c|c|c|c|}
\hline Refeição/Dia & Alimentos & Quantidade & Refeição/Dia & Alimentos & Quantidade \\
\hline Desjejum $\left(1^{9}\right)$ & & & Desjejum $\left(2^{\circ}\right)$ & & \\
\hline Almoço $\left(1^{9}\right)$ & & & Almoço $\left(2^{\circ}\right)$ & & \\
\hline Jantar $\left(1^{\circ}\right)$ & & & $\operatorname{Jantar}\left(2^{\circ}\right)$ & & \\
\hline Ceia (19) & & & Ceia $\left(2^{\circ}\right)$ & & \\
\hline Desjejum $\left(3^{\circ}\right)$ & & & Almoço $\left(3^{\circ}\right)$ & & \\
\hline Jantar $\left(3^{2}\right)$ & & & Ceia $\left(3^{\circ}\right)$ & & \\
\hline
\end{tabular}

RESPONSÁVEL PELO PREENCHIMENTO: 


\section{II - CONDIÇÓES SOCIOECONÔMICAS E ESTADO NUTRICIONAL DO ESCOLAR}

DATA DA COLETA:

$$
\text { FORMULARIO NO }
$$

1. CIEP:

1. OTAVIO C. BORGHI

3. ONIVA BRIZOLLA

2. FILOMENA BASSETTE

4. ANISIO TEIXEIRA

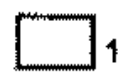

DADOS DO ALUNO

2. NOME:

3. SEXO; 1 Mascutino

2. Feminino

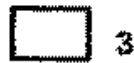

4. DATA DE NASCIMENTO: (idade)

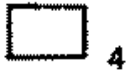

5. PESO (Kg)

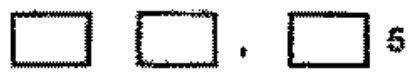

6. ALTURA (Cm)

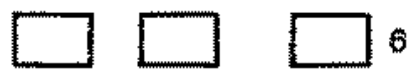

7. SÉRIE QUE FREQÜENTA

\begin{tabular}{|c|c|c|c|}
\hline O) (1) seriel & 03 (3) sériel & 05 (6* serle) & $07\left(7^{*}\right.$ seria) \\
\hline $02\left(2^{x}\right.$ strie) & 04 (4 sétie) & $O B\left(6^{\text {serie }}\right)$ & \\
\hline
\end{tabular}

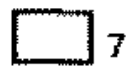

8. QUANTO TEMPO FREQÜENTA A ESCOLA (MESES)

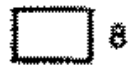

9. FREQUENTOU CRECHE OU PRE-ESCOLA PÚBLICA?
1. SIM
2. NAO

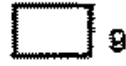

10. QUANTO TEMPO (MESES)
88 naco frequentou
01 meic periodo
99 nac sabe
02 pertoto integral

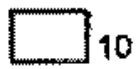

\section{DADOS FAMILIARES}

11. Número de passcas que moram na casa

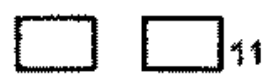

12. IDADE DO PAI

so nos tem

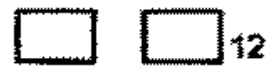

13. Escolaridade do pai (até que sấrie estudou)

b8 sem extudo

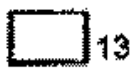

14. Ocupace do pai (setor)

1. atividade agrfoxla

4. servicos

2. atividade industrial

5. outros

3. atividade comercial

6. desempregedo 
15. DENTRO DO SETOR
1. empregado
3. sem declaraçăo
2. empregador
4. autônomo
5. náo remunerado

16. IDADE DA MÄE

88 năo tem

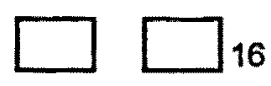

17. Escolaridade da măe (até que série estudou)

88 sem estudo

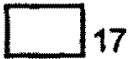

18. Ocupaçăo do máe (setor)

1. atividade agricola

4. serviços

2. atividade industrial

5. nåo trabalha fora

3. atividade comercial

6. desempregado

7. outros

19. DENTRO DO SETOR
1. empregada
4. autónoma
2. empregadora
5. nåo remunerada
3. sem declaração
6. outro

20. Renda familiar (salários minimos)

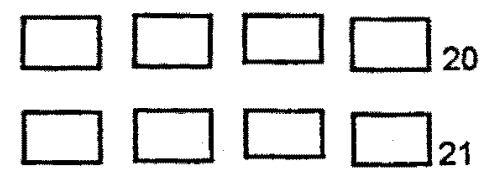

21. Renda familiar per capita (salários minimos)

DADOS SOBRE A HABITAÇÃO

22. TIPO DA CASA
1. Alvenaria
2. năo alvenaria

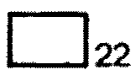

23. TIPO DE ÁGUA UTILIZADA
1. Torneira em casa
3. Pogo, fonte
2. Torneira coletiva
4. Outro

$\square 23$

24. TIPO DE ESGOTO
1. Rede geral
3. fossa negra
5. outros
2. Fossa séptica
4. rio, lago, etc. 


\section{III - REgRESSÕES MÚltiplas PARA Z DE ALTURA PARA IDADE.}

A regressāo mủltipla é uma técnica estatística que permite avaliar a influência de diversas variáveis explanatórias sobre uma variável dependente. Cabe ressaltar que o coeficiente de uma variável explanatória, em uma regressão múltipla, indica a influência dessa variável sobre a variável dependente, depois de descontado o efeito das demais variáveis explanatórias incluídas no modelo.

Neste caso a variável dependente será o ZAl ( $Z$ de altura para idade) da criança e procura-se avaliar a influência da renda familiar, da escolaridade da mãe, do tipo de abastecimento de água, modalidade de esgoto, tipo de casa (alvenaria ou não) o fato de ou crianças terem frequentado ou não creche ou pré-escola.

Para avaliar a influência de todos esses fatores serão utilizados os conjuntos de variáveis binárias definidas a seguir:

a) $C=0$ se o aluno frequentou creche ou pré-escola, e $C=1$ se não frequentou.

b) $H=0$ se a casa é de alvenaria e $H=1$ se não é de alvenaria.

c) Para caracterizar o tipo de abastecimento de água são usadas duas variáveis: $A_{1}=A_{2}=0$ se há torneira em casa; $A_{1}=1$ e $A_{2}=0$ se é utilizada torneira coletiva, e $A_{1}=0$ e $A_{2}=1$ se a água é de poço, fonte ou outra origem.

d) Para caracterizar o tipo de esgoto são usadas duas variáveis: $G_{1}=G_{2}=0$ se é utilizada a rede geral; $G_{1}=1$ e $G_{2}=0$ quando não há esgoto, e $G_{1}=0$ e $G_{2}=1$ se é utilizada fossa negra, rio, lago, etc.

e) São usadas 4 variáveis binárias $\left(E_{i}\right.$ com $\left.i=1,2,3,4\right)$ para distinguir 5 niveis de escolaridade da mãe. As 4 variáveis são iguais a zero se a escolaridade é de pelo menos 9 anos. Se a escolaridade é nula faz-se $E_{1}=1$ e 
$E_{2}=E_{3}=E_{4}=0$. Se a escolaridade é de 1 a 3 anos então $E_{2}=1$ e $E_{1}=E_{3}=E_{4}=0$. Se a escolaridade é igual a 4 anos, então $E_{3}=1$ e $E_{1}=E_{2}=E_{4}=0$. Finalmente, se a escolaridade é de 5 a 8 anos, então $E_{4}=1$ e $E_{1}=E_{2}=E_{3}=0$.

f) São usados 4 variáveis binárias $\left(R_{h}\right.$ com $\left.h=1,2,3,4\right)$ para distinguir 5 níveis de rendimento familiar per capita (RPC), em reais por pessoa: $R P C<25$, $25 \leq \mathrm{RPC}<50,50 \leq \mathrm{RPC}<75,75 \leq \mathrm{RPC}<100$ e $\mathrm{RPC} \geq 100$. No primeiro estrato apenas $R_{1}$ é igual a 1 , no segundo estrato apenas $R_{2}$ é igual a 1 , no terceiro estrato apenas $R_{3}$ é igual a 1 , no quarto estrato apenas $R_{4}$ é igual a 1 e finalmente, no quinto estrato (os mais ricos) as 4 variáveis são iguais a zero.

Utilizando $Z$ para indicar o valor de ZAI, o modelo de regressão fica:

$$
Z=\alpha+\sum_{H+1}^{4} \beta_{h} R_{h}+\sum_{i=1}^{4} \gamma_{i} E_{i}+\delta_{1} G_{1}+\delta_{2} G_{2}+\varphi_{1} A_{1}+\varphi_{2} A_{2}+\theta H+\varpi C+u
$$

onde u é um erro com propriedades usuais (média zero, variância constante e ausência de correlação entre erros de diferentes observações).

Utilizando as $\mathbf{2 4 0}$ observaçōes para as quais se dispõe de todas as informaçōes e a renda familiar per capita é positiva, obteve-se a seguinte equação de regressão para ZAl:

$$
\begin{aligned}
& Z \mathrm{Al}=-0,350-0,543 R_{1}-0,258 R_{2}-0,832 R_{3}-0,315 R_{4} \\
& (-1,42) \quad\left(-2,17^{\star *}\right) \quad(-1,16) \quad\left(-3,35^{\star \star}\right) \quad(-1,19) \\
& +0,214 E_{1}-0,041 E_{2}-0,036 E_{3}+0,151 E_{4}-0,272 A_{1} \\
& (0,52) \quad(-0,15) \quad(-0,14) \quad(0,59) \quad(-1,03) \\
& +0,108 A_{2}-0,223 G_{1}+0,963 G_{2}-0,358 H-0,473 C \\
& (0,36) \quad(-0,89) \quad\left(1,66^{*}\right) \quad(-1,01) \quad\left(-3,06^{* *}\right)
\end{aligned}
$$

Abaixo de cada coeficiente é dado o respectivo teste $t$, que é assinalado com dois asteriscos se for significativo ao nível de $5 \%$, e com um asterisco se for significativo apenas ao nivel $10 \%$. 0 coeficiente de 
determinação dessa regressão múltipla é igual a 0,1665 e o respectivo teste $F$ é 3,21 , significativo ao nivel de $1 \%$.

Verifica-se que todos os coeficientes significativos ao nivel de $5 \%$ apresentam o sinal esperado. No caso de $R_{1}$ e $R_{3}$ o coeficiente negativo indica que nos correspondentes estratos de renda per capita (menos de 25 e de 50 a menos de 75 Reais) o valor esperado de ZAl é menor do que para as crianças do estrato mais rico (100 Reais ou mais), mesmo depois que já foi levado em consideração o efeito dos demais fatores (escolaridade da mãe, tipo de abastecimento de água, etc.).

O coeficiente de $C$ mostra que, depois de descontar o efeito dos demais fatores (renda per capita, escolaridade da mãe, etc.), o valor esperado de ZAI para uma criança que não frequentou creche ou pré-escola é 0,473 unidades menor do que o valor esperado para uma criança que frequentou. 